\title{
EARLY RAILWAY SUBURBS AND THEIR LINKS TO CONTEMPORARY TRANSIT-ORIENTED DEVELOPMENTS
}

Case Study: Town of Mount Royal, Montreal

\section{Zahra Zarabi}

\author{
Urban Design and Housing \\ School of Architecture \\ McGill University, Montreal
}

August 2014

\begin{abstract}
A report submitted to McGill University
in partial fulfillment of the requirements of the degree of

Masters of Architecture
\end{abstract}

CCZahra Zarabi 2014 


\section{Acknowledgments}

It is a pleasure to thank those who made this report possible.

First and foremost, I would like to thank my supervisor Professor Vikram Bhatt for his constant support and encouragement throughout the production of this research paper. I would also like to thank Professor Avi Friedman who provided invaluable suggestions which contributed to the overall quality of this work.

A special acknowledgment goes out to the Post-Professional Master of Architecture Class of 2013, who challenged me academically in a congenial work environment from which I learned enormously. I am also grateful to Miss Marcia King, secretory of graduate programs, for her unwavering helps and support.

Finally, the completion of this degree would not have been possible without the love and support of my family who strove to provide me with the best opportunities in life. 


\section{Table of content}

Title

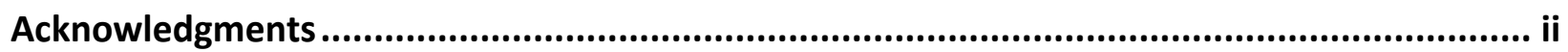

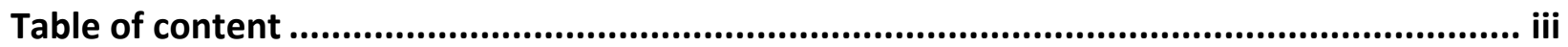

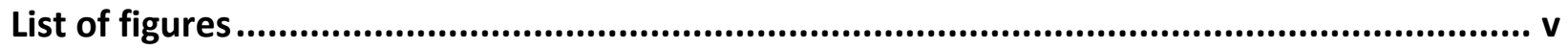

List of Abbreviations..............................................................................................................

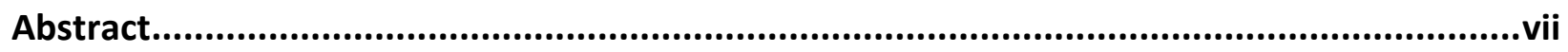

Abrégé ...................................................................................................................................

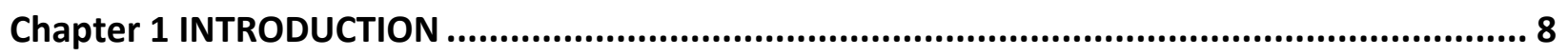

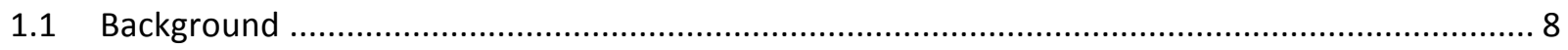

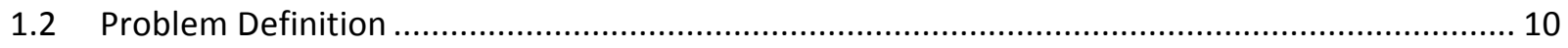

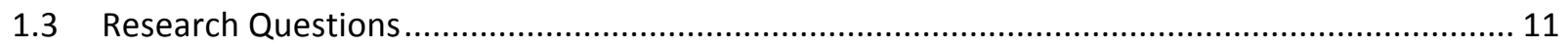

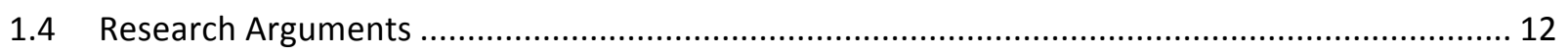

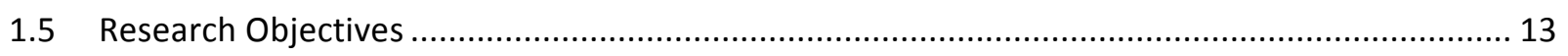

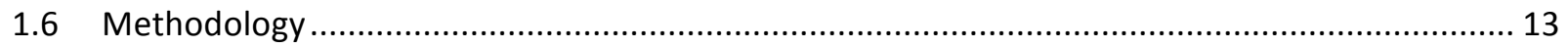

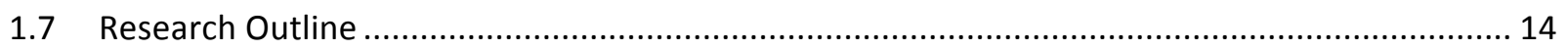

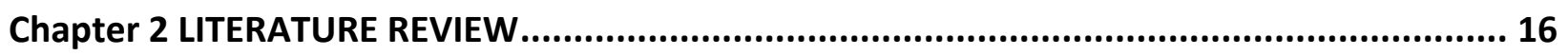

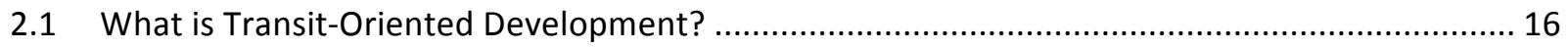

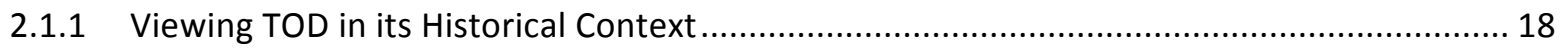

2.1.2 How Does the Built Environment Impact the Transit Ridership? ....................................... 21

2.2 Benefits of Transit-Oriented Development .......................................................................... 21

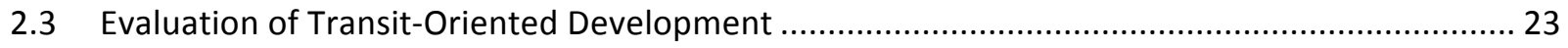

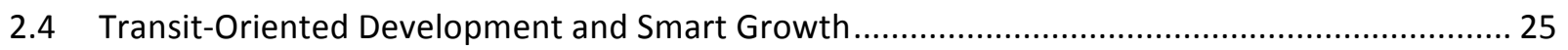

2.5 Transit-Related Development in North America ................................................................. 26

Chapter 3 TOWN OF MOUNT ROYAL, A MODEL CITY AND AN EARLY TRANSIT-ORIENTED

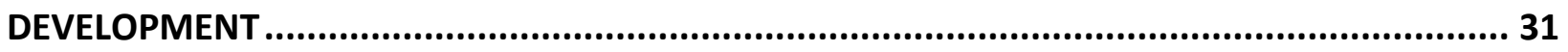

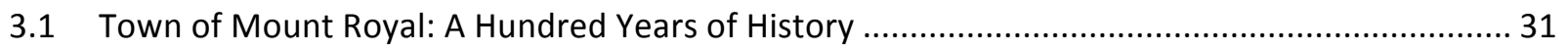

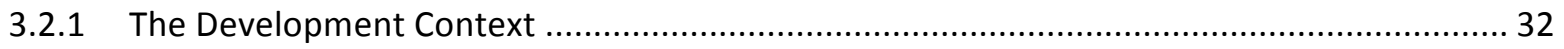




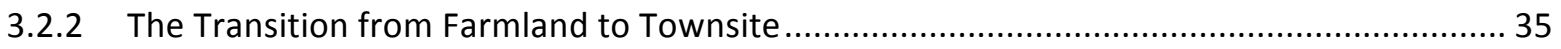

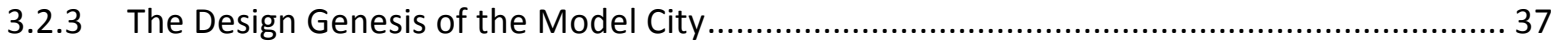

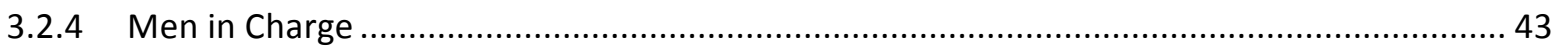

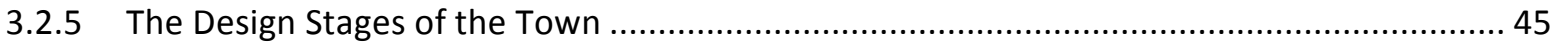

3.2.6 Municipality, Transit Authority, and the Developer ....................................................... 52

3.2.7 Mount Royal Tunnel: A Marvelous Construction ........................................................... 53

3.3 Town of Mount Royal, a Model City and a Transit-Oriented Development............................... 55

3.3.1 Density, Diversity, and Design in Town of Mount Royal .................................................. 56

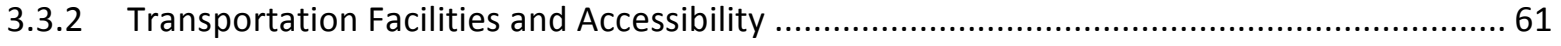

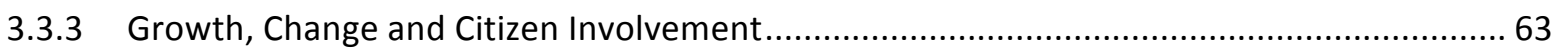

Chapter 4 CANADIAN TODS AND TMR; A COMPARATIVE STUDY ........................................ 65

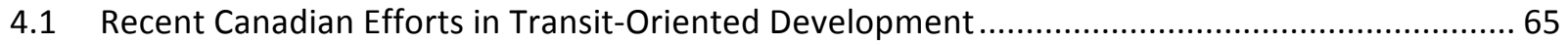

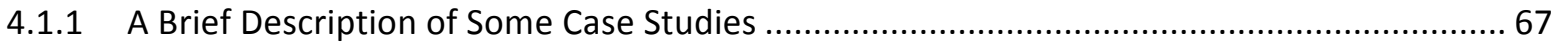

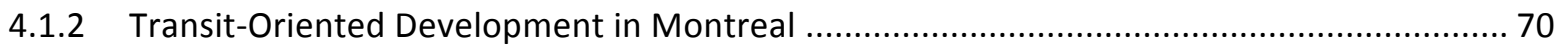

4.2 Comparing Town of Mount Royal with CMHC Research Highlights ........................................ 74

4.2.1 What TOD Features Are Integrated into the Projects? ................................................... 74

4.2.2 Transit: A Motivational Factor for Developers and Occupants ........................................ 78

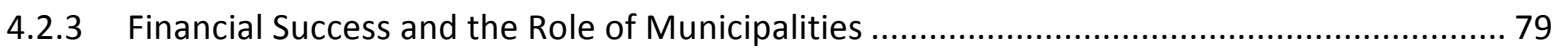

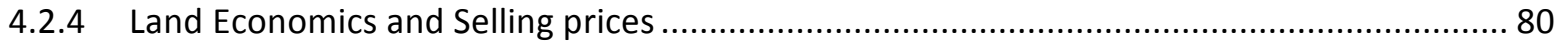

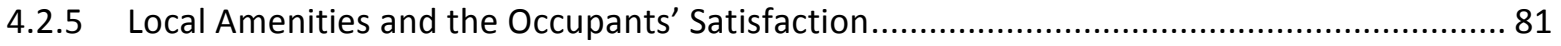

Chapter 5 CONCLUSIONS AND RECOMMENDATIONS ...................................................... 83

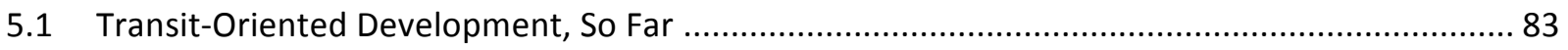

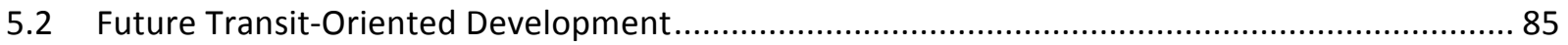

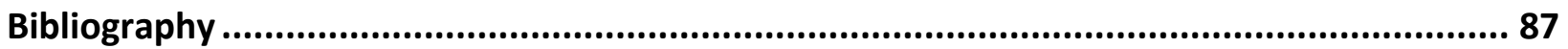




\section{List of figures}

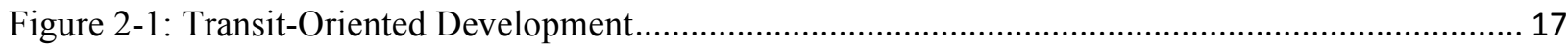

Figure 2-2: Shaughnessy Heights, Vancouver: Plan (1926) (top); aerial view (left); long lines of

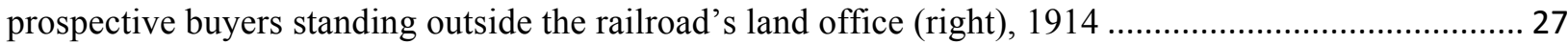

Figure 2-3: Shaker Heights,Cleveland: Development around Rapid Transit Railroad, 1922 .................. 29

Figure 2-4: Chestnut Hill, Philadelphia: Rail station (left) and vibrant commercial main street (right) .... 30

Figure 3-1: The spatial pattern of urban growth in the Montreal area ................................................. 33

Figure 3-2: Town of Mont Royal in relation to Mount Royal Tunnel and central business district of

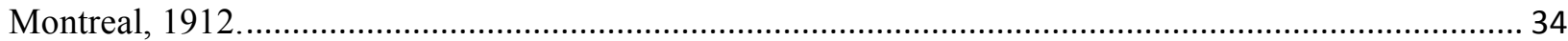

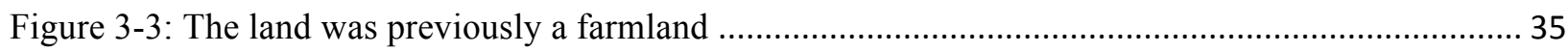

Figure 3-4: Welwyn (Left) and Letchworth (Right) Garden Cities in England ..................................... 39

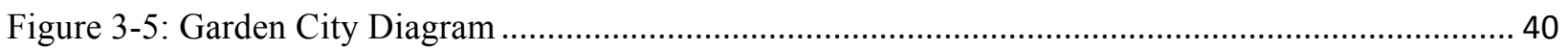

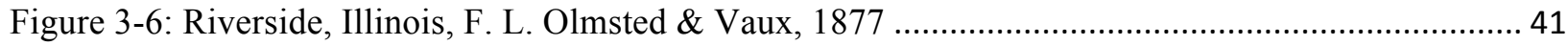

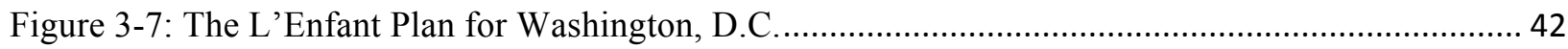

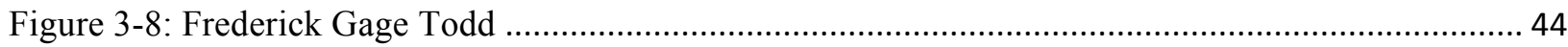

Figure 3-9: Preliminary plans for the layout of Town of Mount Royal ................................................ 46

Figure 3-10: The official plan of the Model City established by CNoR .............................................. 48

Figure 3-11: Bowling Green, Todd's prototype plan for Town of Mount Royal...................................... 50

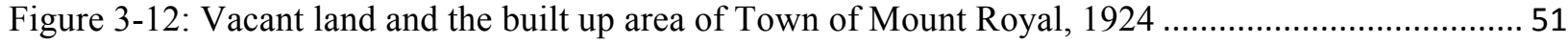

Figure 3-13: Town of Mount Royal Tunnel (left), its station at the Town Center (right) ....................... 54

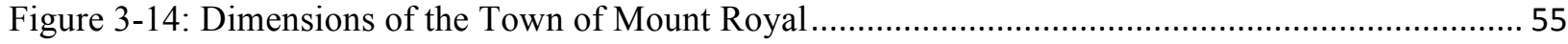

Figure 3-15: Diversity of housing types in Town of Mount Royal ..................................................... 56

Figure 3-16: New higher density residential development close o central station .................................. 57

Figure 3-17: Comparing TOD defined by Calthorpe with Town of Mount Royal .................................. 58

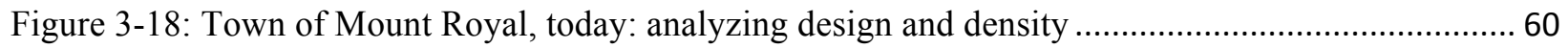

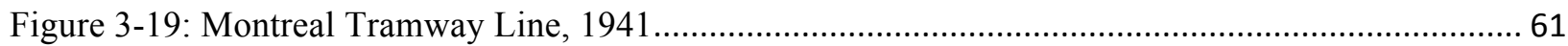

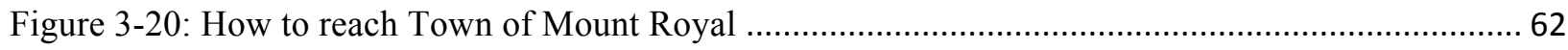

Figure 4-1: Collingwood Village adjacent to Joyce-Collingwood Sky Train Station............................. 68

Figure 4-2: Location and boundaries of the Equinox development ...................................................... 69

Figure 4-3: Acqua (left) and Vento (right), residential units above street-oriented retail ....................... 70

Figure 4-4: Montreal Radial Suburban Train Network including the TOD projects in Sainte-Thérese and

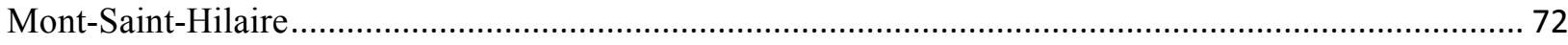

Figure 4-5: Pedestrian-oriented streetscape free of garages and driveways and the train station surrounded by parking in Village de la Gare, Mont-Saint-Hilaire, Quebec........................................................... 73

Figure 4-6: Town of Mount Royal, walking distance to the transit services......................................... 75

Figure 4-7: Pleasant and inviting routes leading to the central train station .......................................... 76

Figure 4-8: Town of Mount Royal, Parks and Local Amenities .......................................................... 82 


\section{List of Abbreviations}

AMT: Agence Metropolitaine de Transport

CMM: Communauté Métropolitaine de Montréal

CLC: Canada Lands Company

CMHC: Canada Mortgage and Housing Cooperation

CNoR: Canadian Northern Railway

CPR: Canadian Pacific Railway

GTR: Grand Trunk Railway

PQAA: Province of Quebec Association of Architects

STM: Société de Transport de Montréal

TAD: Transit-Adjacent Development

TMR: Town of Mount Royal

TOD: Transit-Oriented Development

VMT: Vehicle Miles Traveled 


\section{Abstract}

In the past few decades, Transit-Oriented Development (TOD) has emerged as a promising and influential planning concept throughout North America. It tries to ensure a more sustainable development by integrating land use and transport systems. Numbers of urban planners and transportation scholars formally introduced TOD as a new concept and increased its profile in the 1990s; however, the origins of this concept actually go back much further. There are some noteworthy examples of large-scale real estate developments across North America, developed on properties owned by transit companies, with the aim of generating revenue for the transit company and the government. One of the most successful examples of this type of development is the Town of Mount Royal located in Montreal, Canada. This suburban development which emerged at the dawn of the twentieth century predates, by almost a century, the contemporary concept of TOD. This paper looks at this development comprehensively and discusses the lessons learned from it. Additionally, the research looks at several recent Canadian TOD case studies and through a comparative study reveals the successes and challenges old and new developments faced within their design and operation process. Finally, the study concludes by identifying the key lessons from old and new TODs showing how the present day TOD norms have grown out of such old communities. 


\section{Abrégé}

Au cours des dernières décennies, Transit-Oriented Development (TOD) a émergé en Amérique du Nord comme un concept de planification prometteur et influent. Il tente d'assurer un développement plus durable par l'intégration de l'utilisation du sol et des systèmes de transport. Quelques planificateurs et chercheurs de transport urbain ont officiellement présenté le TOD et ont rehaussé son image dans les années 1990; Cependant, l'idée de ce concept est beaucoup plus ancienne. Il y a quelques exemples de grands projets immobiliers en Amérique du Nord qui sont développés sur des propriétés appartenant à des organismes de transport en commun dans le but de générer des revenus pour l'agence de transport en commun et le gouvernement fédéral. L'un des exemples les plus réussis et les plus notables de ce type de développement est la Ville de Mont-Royal à Montréal, Canada. Ce développement de la banlieue qui a émergé à l'aube du XXe siècle précède la notion contemporaine de TOD. Cet article examine cette évolution globalement et examine les leçons tirées. En outre, la recherche porte sur plusieurs études de cas modernes de TOD canadien et par une étude comparative révèle les réussites et les défis que les anciens et nouveaux développements ont rencontrés au cours de leur processus de conception et de fonctionnement. Finalement, l'étude conclut en identifiant les principaux enseignements des anciens et des nouveaux TOD et révèle si les normes actuelles de TOD sont développés à partir de ces communautés. 


\section{Chapter 1 INTRODUCTION}

This chapter introduces the research and justifies the purpose of the study; then, it describes the aim and objectives of the research, and poses research questions. In addition, methodology and a conceptual framework of the study are also included.

\subsection{Background}

Cities face various sustainability challenges, like suburban sprawl, inefficient infrastructure utilization and poor land resource allocation, traffic congestion and environmental pollution and so on. The efficient integration of land use and transportation planning is a widely proposed solution to address these problems and create more sustainable communities especially in our increasingly urbanizing world (Bertolini, le Clercq, \& Kapoen, 2005).

At the dawn of the twentieth century, urban development and transit were coevolving. The were partners in city building; indeed, the urban center and streetcar suburbs characterized unique forms of metropolis in North America (Calthorpe, 2004). After the Second World War, however, this balance was considerably disrupted by urban decay and consequently the sprawl. This pattern of growth, which dominated city landscapes for many years, was much more facilitated by automobile affordability. By the 1970s and 1980s, low land values and abundant space attracted residents who were previously living in the downtown core to the suburban settlements (Badoe \& Miller, 2000; Dunphy, 2005; Easley, 1992). The combined decentralization of housing and employment required larger amounts of land and infrastructure to accommodate this cardependent development leading to creation of sprawl which is defined as low-density automobile-oriented development with separation of residential and other urban land use. 
In addition, since public transit was limited and uneconomical in low-density areas, residents relied heavily on their cars, resulting in longer commuting times and increased congestion on regional highways (Badoe \& Miller, 2000; Dunphy, 2005; Easley, 1992). Today, the high proportion of car trips has led to increased pollution, greenhouse gas emissions, frustration from highway gridlock and significant spending on expanding infrastructure in low-density neighborhoods.

For the past decade, design professionals have put forward different planning theories and concepts to address these mounting challenges and evolving conditions. The concept of accessibility as an interface between transport and land use interactions is one of the first approaches that has provided a useful framework for the integration of transport and land use planning (Bertolini, le Clercq, \& Kapoen, 2005). Another comprehensive approach that pursues such integration is the Transit-Oriented Development (TOD) concept, which is the main topic of this report. TOD tries to reduce the negative effects of sprawl by decreasing reliance on the automobile. Reducing automobile dependence would yield significant benefits for cities throughout North America, as well as improve the social and economic prosperity of its communities. However, with much of the city already built, the challenge will be for planners to promote developments that increase density and capitalize on existing transportation infrastructure. At the same time, developers need to respond to demand for the amenities these neighborhoods require, while municipalities seek to improve land use and the efficiency of their transit investment. Transit-oriented development, or TOD, has been presented as a paradigm that integrates these two elements: traditional neighborhood design and transit to alleviate the economic, social and environmental consequences of sprawl. 
The integration of public transportation and land use, however, dates back to the dawn of the twentieth century. There are many examples of real estate developments across North America, built on properties owned by transit companies with the aim of generating revenue for the transit company and the government. One of the most successful and notable examples of this type of development is the Town of Mount Royal located in Montreal, Canada. Emerged in 1912, this suburban development was later referred to as "Model City" because of the then unique planning of its residential areas. This case is comprehensively studied in the third chapter.

\subsection{Problem Definition}

Today, in North American cities we have unhealthy dependency on oil to power private vehicles, which have become the primary means of transportation (Altune \& Auld, 2011). Additional cars, which emit $\mathrm{CO}_{2}$, carbon monoxide and deplete oxygen, produce pollution and unhealthy living conditions in many cities. The working poor, middle class, and wealthy each navigate through increasingly congested autoroutes. To mitigate this increased demand, government at all levels are committed to increase public mobility; however, they appear unable to consistently and adequately fund public transit systems. This problem requires the fulfillment of thoughtful civic visions and implementation of efficient city planning schemes.

However, with today's culture and technology the old urban and suburban lifestyle and dream is changing. Our household makeup has also changed dramatically, the work place and work force have been transformed, average family wealth is shrinking, and serious environmental concerns have surfaced (Calthorpe, 1993). Over the last thirty years, the patterns of growth we used to adopt have become more and more dysfunctional. Finally they have come to produce 
environments, which often frustrate rather than enhance everyday life and have brought a wide range of problems including:

- Inefficient land use

- Waste of energy and resources

- Air pollution due to oil and gas consumption because of automobile reliance

- Unhealthy lifestyle

- Non-affordable transportation costs

- Separation of different income households

The present study discusses the new direction for growth through the use of TODs and what they can bring to our cities.

\section{$1.3 \quad$ Research Questions}

In the late twentieth century, the concept of transit-oriented development emerged as a key strategy to manage the problematic effects of growth. Consequently, numbers of TODs were and are being developed in cities across Canada. However, many older more established neighborhoods and urban centers built before WWII successfully integrated transportation infrastructure and services into community design. Town of Mount Royal is one of the notable examples of this type of developments and the focus of this report. Although this Town was developed prior to the appearance of the term TOD, it employed many of its concepts. The report explores this by addressing the following research questions:

- Which TOD principles are integral to the design of Town of Mount Royal? 
- How did our past generation address the issue of suburban growth and urban spreading in comminutes like Town of Mount Royal?

- How closely related are the present day TOD norms to such communities?

- How does Town of Mount Royal stack up with modern Canadian TODs?

\subsection{Research Arguments}

The alternative to sprawl is simple and timely: neighborhoods of housing, parks, and schools placed within walking distance of shops, civic services, jobs, and transit - a modern version of the traditional town (Calthorpe, 1993). Peter Calthorpe calls such neighborhoods Pedestrian Pocket or Transit-Oriented Developments.

The development of the Town of Mount Royal started in 1900. The design of the Town was strongly influenced by the aspects of the "Garden City" movement as well as some elements of the earlier City Beautiful movement both of which facilitated pedestrian orientations. The modern TOD concept also shares much in common with the idea of the "Garden City". Comparing to the principles of the new TODs, Town of Mount Royal is similarly a selfsufficient and diverse suburban community centered on a commuter train system. By organizing growth around a significant transit hub, this Town provides convenience for its residents, gives them the opportunity to walk everywhere, use transit daily, and live in an environment with local access to the daily needs such as shopping and schools.

Town of Mount Royal predates TOD, by almost a century; however, many of its significant design principles can be found in later TODs. In this regard, this study discusses how we stand on the shoulder of our past generation in the designs of our TODs today. 


\section{$1.5 \quad$ Research Objectives}

This study has several main objectives including:

- Study of the design genesis of Town of Mount Royal, analyzing its design concepts, planning and building.

- Study of a cross Canada survey of TODs, particularly the methodology and comparative outputs to compare new TODs with Town of Mount Royal

- Investigating the success factors and challenges that both Town of Mount Royal as an early suburb and modern TODs have faced during their design and operation process.

- Exploring the similarities and differences between old and new TODs to clarify how today's TOD norms have grown out of such communities.

- Formulating recommendations for new developments based on the lessons learned from both old and new TODs.

\subsection{Methodology}

The methodology adopted in this research was based on reviewing TOD concepts and principles using the current literature. Furthermore, primary data related to Town of Mount Royal was collected from the Town itself, the Town's library and City Hall's archives as well as the archives of Canada Northern Railway and local newspaper articles. Different project components of the Town were analyzed. Also, the cross Canada survey of TODs done by Canada Mortgage and Housing Corporation was studied and their methodology and comparative outputs were analyzed. Among ten recent examples of TOD examined by $\mathrm{CMHC}$, four projects were selected for further analysis to reveal shades of norms, which moves the study forward. Based on the norms found in literature and CMHC study, the site of the Town of Mount Royal was 
comparatively analyzed. Finally, the research outcomes were consolidated and analyzed according to the framework used by CMHC.

\subsection{Research Outline}

This thesis consists of five chapters including the introduction. Chapter two examines the relevant literature related to TOD and explores many of its benefits and impacts on travel behavior. Then, some case studies of transit-related developments across North America are reviewed. These cases are introduced as the probable origins of today's TOD concepts. This provides a strong basis for the next two chapters by showing similarities between the old and new concepts and norms of transit-oriented developments.

The third chapter contextualizes the case study, Town of Mount Royal, as an example of an early suburban community, which was developed adjacent to a major transit line in Montreal. The design genesis of the Town and the Mount Royal tunnel as a marvelous construction are explained. An overview of the development stages as well as the role of municipality, transit authority and the developer is presented. The chapter concludes with lessons learned from Town of Mount Royal as a transit-oriented development.

Chapter four introduces a cross Canada survey of TODs done by Canada Mortgage and Housing Corporation and presents an overview of their methodology and comparative outputs. The success factors and challenges that both Town of Mount Royal and modern TOD case studies have faced during their process of design and operation are discussed. Based on the comparative outputs, the study discusses the relationship between old and new TODs. 
Chapter five concludes by discussing the similarities and differences between an early suburban community like Town of Mount Royal and modern TOD case studies. Identifying the key lessons from old and new TODs, the study shows how present day TOD norms have grown out of such communities. Finally, based on the lessons learned, some recommendations are made for future TODs. 


\section{Chapter 2 LITERATURE REVIEW}

This chapter presents an overview of literature regarding the topic of transit-oriented development and its evolution in the historical context. TOD benefits and the indicators of measuring them as well as the link between TOD and smart growth are provided, thus, setting up background for the research and a theoretical framework for the study based on previous researches done on the topic. Finally, it reviews some case studies of early transit-related developments across North America to build up the argument for the next two chapters.

\subsection{What is Transit-Oriented Development?}

Transit-oriented development incorporates several planning and design concepts including: regional planning, city revitalization, suburban renewal, and walkable neighborhoods (Calthorpe, 2004). It is a cross-cutting approach to development that can do more than help diversify our transportation systems: it can offer a new range of development patterns for households, businesses, towns, and cities. TOD is an alternative that provides choice not only in transportation modes but also, more fundamentally, in lifestyle. As we confront the regional issues of open space preservation, congestion, air quality, affordable housing, affordable lifestyles, and mounting infrastructure costs, TOD and its complex web of transit modes will become a more and more important strategy for sustainable growth.

While there is no single definition of TOD available, a common characteristic of the concept is illustrated by the California Department of Transportation in 2002: "Transit-oriented Development (TOD) is moderate to high-density development, located within an easy walk of a major transit stop, generally with a mix of residential, employment and shopping opportunities 
designed for pedestrians without excluding the auto. TOD can be new construction or redevelopment of one or more buildings whose design and orientation facilitate transit use."

There is also the original and most popular definition of this concept, which came from Peter Calthorpe, an architect and proclaimed New Urbanist. According to Calthorpe (1993), TODs are:

"Mixed-use communit[ies] within an average 2,000-foot walking distance of a transit stop and a core commercial area. TODs mix residential, retail, office, open space, and public uses in a walkable environment, making it convenient for residents and employees to travel by transit, bicycle, foot or car (p. 56)."

In addition, the transportation hub should be located in the heart of the neighborhood, within a 400 meter, or 10 minute walk from residents (Nelson \& Niles, 1999; Nelson, Niles, \& Hibshoosh, 2001). This central location reflects the importance of transit in the community and in the region as a whole (Figure 2-1).

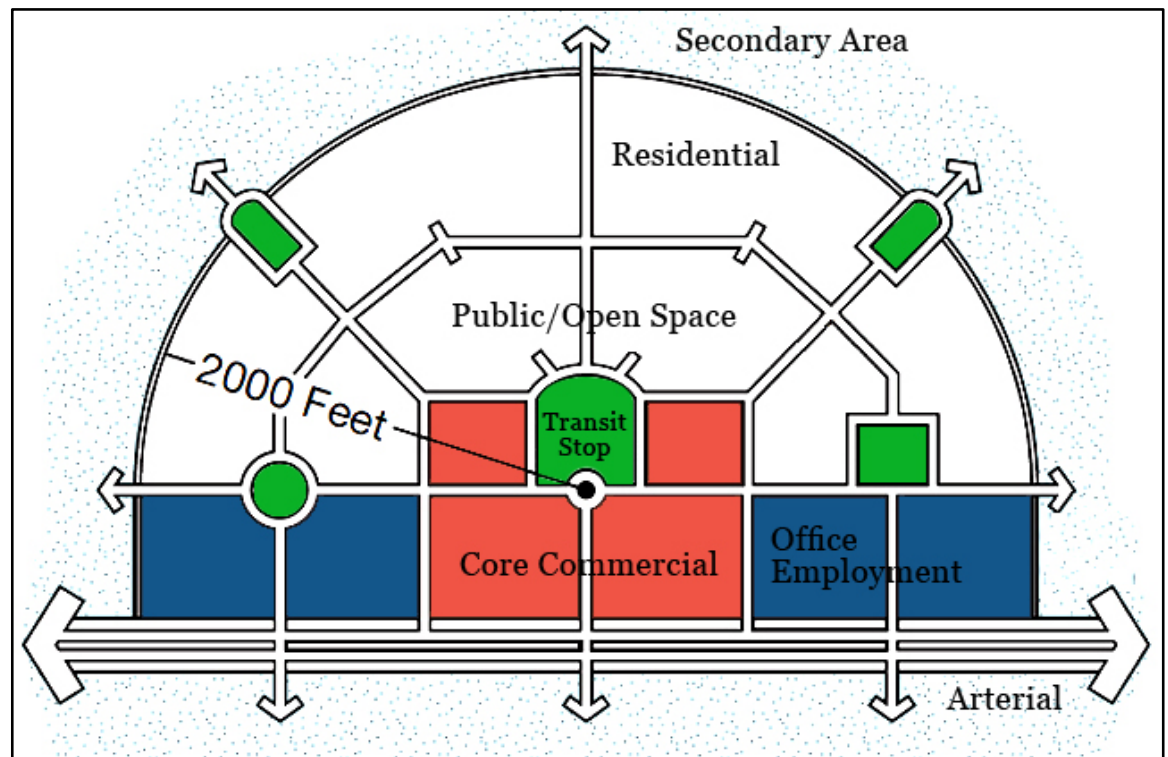

Figure 2-1: Transit-Oriented Development

Source: Diagram based on Peter Calthorpe's illustration of TOD in The Next American Metropolis, Ecology, Community, and the American Dream (1993). 
Calthorpe, brought together the notion of pedestrian pocket with the idea of planning development around transit stations. In his book, The Next American Metropolis, he began to articulate the urban design principles associated with TOD (Dittmar \& Ohland, 2004):

- Organize a compact and transit-supportive growth.

- Place commercial, housing, jobs, and civic uses within walking distance of transit stops.

- Create pedestrian-friendly street networks that connect local destinations.

- Provide a mix of housing types, densities, and costs.

- Preserve sensitive habitat and high-quality open space.

- Orienting buildings and neighborhood activities around public spaces.

- Encourage infill and redevelopment along transit corridors within existing neighborhoods.

In essence, the ideas expressed by Calthorpe call for better integration between land use and transportation policy (Renne \& Wells, 2004). This integration is what differentiates TOD from every other development. TOD takes traditional neighborhood design one step further by coordinating transportation infrastructure and characters of the built environment needed to support transit use.

\subsubsection{Viewing TOD in its Historical Context}

Although Calthorpe, transportation scholar Cervero, and others have formally introduced TOD and increased its profile in 1990s, the origins of TOD actually go back much further (Jacobson \& Forsyth, 2008). Transit-oriented development should be viewed in a historical context. Cities have always been shaped by their transportation modes since the advent of the horse-drawn streetcar (Dittmar \& Ohland, 2004). Before the advent of the automobile, many of the urban 
design patterns that we try to rehabilitate today were common. While TOD may not be a new thing, the challenge of adapting it to the auto-oriented metropolis is.

The first era in the historical context was development-oriented transit (Dittmar \& Ohland, 2004). The early twentieth century streetcar suburbs evolved in a setting that no longer exists. They were developed by a single owner or an entrepreneur in a way that brought residential communities and streetcar lines adjacent to each other. This strategy was to add value to the residential development by providing a link between jobs in an urban center and housing at the periphery. As part of this strategy, streetcar stops often had small retail clusters to serve commuters as well as local residents. These small commercial districts are, to some extent, the precursor of modern TOD and represent a good balance between place and node. However, starting in 1930s, the automobile and roads, including highways broke apart the interdependence between housing, jobs, and public transit.

The postwar period of auto-oriented developments saw a sudden decline in collective transit use and abandonment of many rail and tram systems (Dittmar \& Ohland, 2004). Buses also became the primary mode of transit in most cities. Bus systems are subordinate to the automobile and in most cases their service has less influence on land use patterns than fixed-rail transit. Transit became the travel mode of last resort and except for some commuter suburbs around older cities such as Boston, New York, and Chicago, transit ceased to shape developments which were functioning reasonably well as transit based communities. Consequently, the automobile and individual transport-oriented developments became dominant. As congestion worsened, a new generation of public transit systems was planned and built in, 1970s, such as Metropolitan Area Transit Agency (MATA). However, the idea that development should be linked to transit generally was not part of the philosophy of these systems. These systems were designed under 
the assumption that most people would still use their cars to go to suburban stations rather than walk, bike, or ride the bus. Because of this, many stations were surrounded by large amount of parking rather than being integrated to the neighborhoods they serve. Overall, the systems failed to contribute to neighborhood revitalization, to reduce automobile dependency significantly, or to encourage more efficient regional land use patterns.

Today is the age of transit-related development (Dittmar \& Ohland, 2004). Similar to what took place at the Town of Mount Royal, usually rail systems enhance the value of adjacent land. Government and transit agencies see large-scale real estate development on that property as a way to partially reimburse the rail investment. Promoting intense development around transit stations which is called "joint development" has gained notable success in places like Washington D.C. and Portland. The emphasis of joint development in Town of Mount Royal was on a dense, profitable real estate development aimed at generating revenue for Canadian Northern Railway Company. However, these forms of developments are somehow problematic because they were predicted on a purely financial rational rather than a broad vision of how transit could work in tandem with surrounding development (Dittmar \& Ohland, 2004). Also, some projects can clearly take advantage of being adjacent to transit to reduce parking but they still use standard parking ratios, indicating an underlying assumption that these projects will primarily be auto-oriented. Some other projects contain a variety of uses but still lack "appropriate" mix and residential sector of some developments do not include units targeted at a mix of income groups or household sizes. Most current projects fall short of the realistic vision of transit-oriented development, and as a result they are called transit-related development, a name that acknowledge the connection they have made between transit and development while still recognizing their shortcomings. 


\subsubsection{How Does the Built Environment Impact the Transit Ridership?}

The relationship between the built environment and travel behavior has been studied extensively. Previous research (Boarnet \& Crane, 2001; Frank \& Pivo, 1994; Moudon, Hess, Snyder, \& Stanilov, 1997; Tumlin \& Millard-Ball, 2003) looks specifically at the effects of density on travel demand, arguing that higher residential and employment densities have a positive relationship with transit ridership. Due to the different perception of the concept, researchers have emphasized various sides of TOD some like Bernik and Cervero (1996) mainly focused on the measures of the built environment for how urban form affect travel behavior and highlighted the role of the "three Ds" (Density, Diversity, and Design) in the success of TOD. These three physical principles are the key ingredients that create ideal TODs. However, later they were followed by destination accessibility and distance to transit as "two more Ds" and demand management, including parking supply and cost, as the "sixth D" (Ewing \& Cervero, 2010).

The above mentioned factors are within the influence of municipalities. However, there are also non-built environmental factors that affect transit use. The amount and type of transit use which are within the sphere of influence of a transportation agency. Other factors such as topography, demographics, and income levels also impact transit ridership and cost of running the transit system (TransitLink, 2010).

\subsection{Benefits of Transit-Oriented Development}

Various studies indicate that implementing TOD can have significant benefits to individuals, communities, regions, states, the economy and the natural environment. The extent that these benefits are realized depends on whether developments have the primary characteristics of TOD, and on the type and quality of transit service available. In theory, residents who have access to 
high-quality transit are more likely to take transit than those living without the same access (Cervero, 1994; Lund, Cervero \& Wilson, 2004). TOD encourages higher transit use, thus also reducing the number of vehicle miles travelled, or VMT. When people drive less, the economic, social and environmental well-being of the city (similarly, the globe) is improved.

The economic benefits of TOD are plentiful for all stakeholders. First, land owners and developers benefit from higher land values and rents. According to Renne (2005), proximity to transit increases both the demand and price for commercial and residential properties. Haider and Miller (2000) reported that the average price of a house within a kilometer of a transit station was $21 \%$ higher than the average of similar housing sold in nearby non-TODs. While land values are a useful measure of the benefits of TODs, there are several other economic benefits that should be considered. Fewer vehicles, for example, decrease the need for expensive infrastructures. Compact developments such as TODs, can help reduce infrastructure costs for expanding water, sewage and roads to local governments and property owners by up to 25 percent through more compact and infill development patterns (Renne \& Wells, 2005). TOD is also increasingly used as a tool to help revitalize aging downtowns and declining urban neighborhoods, and to enhance tax revenues for local jurisdictions (Parker et al., 2002). TOD can add to the supply of affordable housing by providing lower-cost and accessible housing, and by reducing household transportation expenditures. Housing costs for land structures can be significantly reduced through more compact growth patterns.

TOD also brings several environmental benefits. Safe and easy access to transit allows households to significantly reduce their rates of air pollution and energy consumption (Regional Transportation Authority, 2014). Also, because TOD consumes less land than low-density, autooriented growth, it reduces the need to convert farmland and open spaces to development. 
In addition to the environmental and economic benefits of TOD mentioned above, there are several social advantages for residents living in TODs. TOD allows, at least potentially, a degree of human interaction in the public domain or urbanity that is difficult if not impossible to achieve in much more socially segregated car-dependent urban environments (Bertolini, 2000). Like traditional neighborhoods in urban areas of the city, TOD brings people from diverse social background into one vibrant community (Bernik \& Cervero, 1997). Therefore, there is a need for pleasant streets, public spaces and community centers that can meet the diverse needs of this group. The TOD's mix of housing, employment, retail and recreation supports these activities by diversifying the types of movement in one area. By creating places that are active and have pedestrian traffic through the day and evening and providing the "eyes on the street", TOD helps increase safety for pedestrians, transit users, and many others (Renne \& Wells, 2002).

Finally, transit and transit-oriented development are essential parts of the toolkit for healthy metropolitan economics and improved quality of life. However, these two parts have their limitations, their autos, highways, and suburbs are also integral parts of the toolkit, and that a return to the era of streetcar suburbs is neither possible nor necessarily desirable (Calthorpe, 2004).

\subsection{Evaluation of Transit-Oriented Development}

Without measuring the TOD outcomes, mistakes in investments strategies will continue to be repeated and lack of coordination between land use and transportation planning can lead to disappointing results (Renne et al., 2005). Cervero et al. (2004) have also stated that while most research has been done to evaluate the transit ridership and probable effect on the land value, other aspects remain rather neglected. 
Some other researchers believe that although analyzing the built form and physical dimension is necessary, it is not sufficient, hence Belzer and Autler (2002) introduced 30 performance indicators under the six groups as follows to evaluate TOD outcomes:

\section{Location efficiency}

2. Value recapture

3. Livability and place making

4. Financial return

5. Rich mix of choices

6. Efficient regional land use patterns

Further to this, as part of National Cooperative Highway Research Program (NCHRP), Renne et al. (2005) investigated 56 existing indicators (physical as well as performance measures) to evaluate the sustainability of TODs based on six aspects of outcomes, including travel behavior, the local economy, the natural environment, the built environment, and the policy context. They carried out a survey amongst transport professionals and suggested a list of top ten indicators for evaluating TODs as below:

1. Transit Ridership

2. Density

3. Quality of Streetscape

4. Quantity of mixed-use structures

5. Pedestrian activity and safety

6. Increase in property value

7. Increase in tax revenue 
8. Public perception

9. Number of mode connections at the transit station

10. Parking

\subsection{Transit-Oriented Development and Smart Growth}

Over the past few decades achieving sustainability as a common concern has been discussed by many researchers and specifically in the context of urban planning, various strategies and tools have been proposed to reach it. Smart Growth and transit-oriented development as a means of it are the two powerful tools which have been proven to support sustainability in different aspects (Cervero, Arrington, Dunphy, \& Smith-Heimer, 2004).

Sprawl is a common label for the low-density, auto-oriented spread of metropolitan regions that increases traffic, saps local resources and destroy open space. Such concerns have contributed to the growing momentum of the "smart growth" movement (Handy, 2005). Increasingly, planners and decision-makers are praising smart growth as the key to halting sprawl and leading the way toward more sustainable communities (CUTA, 2004). The connection between transportation and land use lies at the center of efforts throughout North America to combat sprawl through smart growth strategies (Handy, 2005). According to American Planning Association (2002, 2), "Compact, transit accessible, pedestrian-oriented, mixed use development patterns and land reuse epitomize the application of the principles of smart growth". All of these strategies are also in the same direction as the objectives of TODs. 


\subsection{Transit-Related Development in North America}

Development facilitated by transit is as old as transit technologies themselves (Jacobson \& Forsyth, 2008). The origins of TOD go back much further than that of introduced by Calthorpe and Cervero in the 1990s. The concept, in particular, can be found in what Warner introduced in "Streetcar Suburbs: The Process of Growth in Boston" in 1962 - i.e. "the typical streetcaroriented development patterns that defined many North American cities, serve as precursors for contemporary TOD" (Jacobson \& Forsyth, 2008). There are also signs of the idea of "Garden City"1 in which more or less self-sufficient suburbs are centered on commuter train stations in modern TODs. In fact, the contemporary idea of TOD is in so many ways similar to traditional urban forms and suburban-style development which were for many years the typical form of development across North America.

Based on the discussion above and what was mentioned in the "TOD in historical context" part in this chapter, several cases of transit-related developments are discussed here. These types of developments, a very distinguished example of which is comprehensively introduced in the next chapter, are somewhat the starting point of today's transit-oriented developments.

- Shaughnessy Heights, Vancouver, British Columbia

In 1885, the provincial government of British Columbia gave the Canadian Pacific Railway (CPR) 6000 acres of prime land in the heart of Vancouver (City of Vancouver, 2014). The CPR Company, the city's largest landowner and the driving force behind Shaughnessy Heights' early development, selected the best partition of that land for its premier residential development (Figure 2-2).

\footnotetext{
${ }^{1}$ In 1989, the Garden city Movement was initiated by Ebenzer Howard in the United Kingdom.
} 

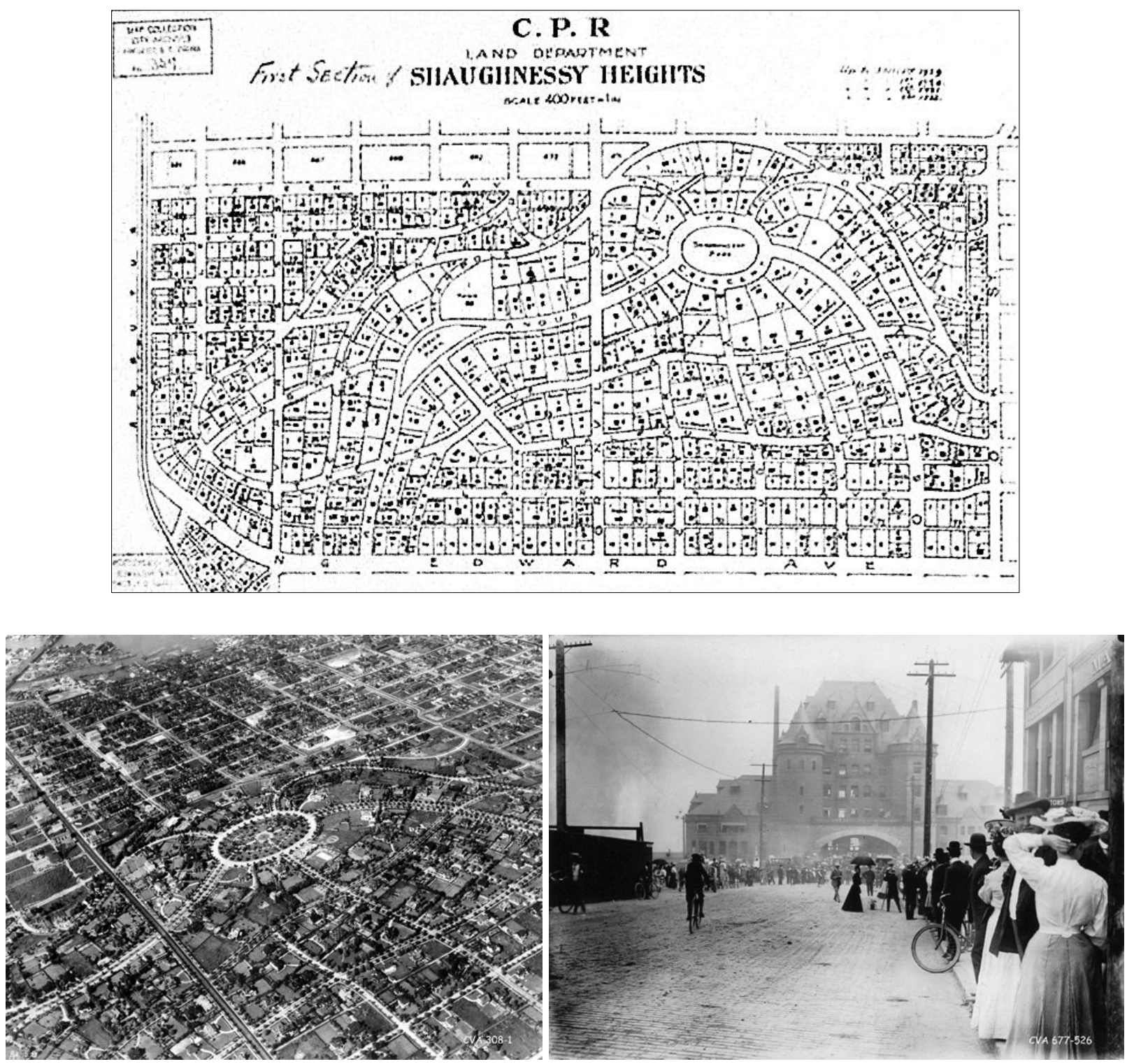

Figure 2-2: Shaughnessy Heights, Vancouver: Plan (1926) (top); aerial view (left); long lines of prospective buyers standing outside the railroad's land office (right), 1914

Sources: Stern, Fishman \& Tilove, 2013; South Granville, 2011

The railway hired Montreal landscape architect, Frederick Gage Todd, and Danish Engineer, L.

E. Davick (n.d.), to lay out curving streets and generous lots. They integrated open spaces into a hybrid of orthogonal streets on the level land and curvilinear streets meeting in Y-shaped intersections in the hillier areas (Stern, Fishman \& Tilove, 2013). The plan included a circular park that acted as a hub for five boulevards. Todd's landscape plan also called for diverse tree 
species to be placed along the streets between the curb and the sidewalk. Reported by CPR Company, the transport connection, however, was weak in the case of this project.

At the beginning of the twentieth century, urban growth in Canada was spurred by massive immigration and the highlighted vision of the railroad companies who were busy linking 3000 miles of Canadian territory, and in the process developing many of Canada's newest "garden cities" (Jacobs, 1983). Shaughnessy Heights is one of the model urban communities designed by Frederick Todd. According to what he said in Point Grey Gazette (1907), the Shaughnessy Height was described in the following manner:

"Instead of the conventional style of streets crossing at right angles, the center of the heights was laid out in the form of a park, with streets radiating in different directions like the spokes of a wheel; intertwined with these are the boulevards and other smaller park spaces" ${ }^{2}$.

- Shaker Heights, Cleveland, Ohio

Shaker Heights is an old inner-ring streetcar suburb of Cleveland, adjacent to the eastern edge of the city's limits, which was established in 1809 and incorporated as a village in 1912 (Wikipedia, 2014). Shaker Heights was a planned community developed by the Van Sweringen brothers, railroad moguls who envisioned creation of an exclusive, utopian residential suburb built around the ideals of the Garden City movement and, at the same time, retreat from the industrial innercity of Cleveland. The Sweringens established a rapid transit interurban streetcar system that would carry residents of Shaker Heights to and from downtown Cleveland. The resulting system was known as the Shaker Heights Rapid Transit. One hundred years later, the transit system is

\footnotetext{
${ }^{2}$ Frederick G. Todd, "Premier Residential District of British Columbia," Point Grey Gazette, 1907.
} 
still providing easy access to Cleveland and remains one of the Shaker's most desirable and unique assets.

Integrating the natural landscape with the built environment was a key component of the Garden City movement and a guiding development principle for the brothers. Planners also created an intentional hierarchy of streets to limit traffic in residential neighborhoods, creating a quiet environment. The combination of natural beauty of the community and easy access to rapid transit enticed hundreds of families to build homes there. This explosive growth took place between 1920s and 1930s when families moved to the village at a rate of one a day (Figure 2-3).

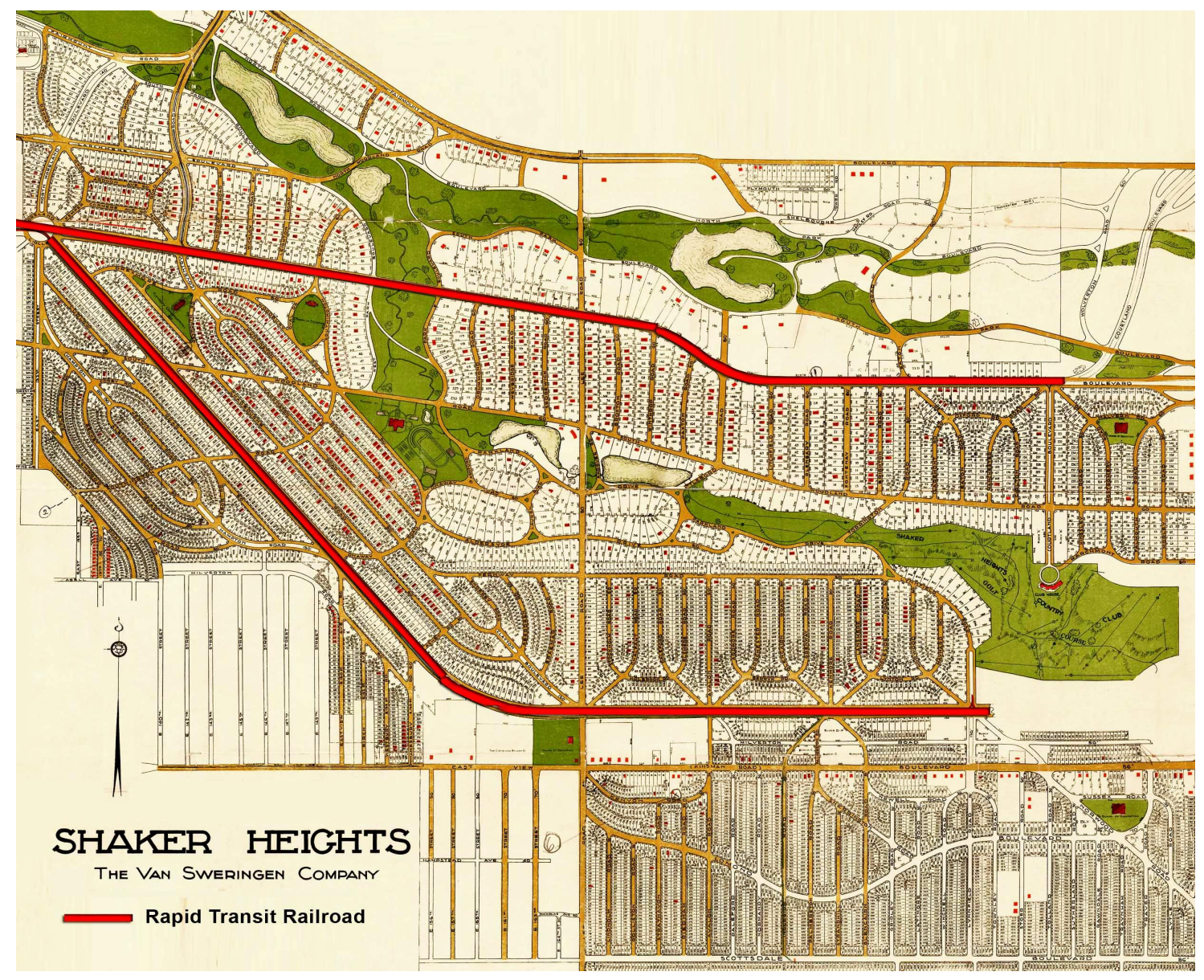

Figure 2-3: Shaker Heights,Cleveland: Development around Rapid Transit Railroad, 1922 Source: Courtesy Cleveland State University Special Collection Library 


\section{- Chestnut Hill, Philadelphia}

Chestnut Hill is a beautiful, affluent and historic neighborhood in the Northwest Philadelphia, which serves as a gateway between Philadelphia and the nearby farmlands. In the year 1854, the Chestnut Hill Railroad, opened, making an easy commute to and from Center City (Wikipedia, 2014). From the mid- $19^{\text {th }}$ century through the mid- $20^{\text {th }}$, the neighborhood served both as a "railroad suburb" and a "streetcar suburb" of Center City. This village was part of Philadelphia; however, a leafy outlying part functioning as a bedroom community (Figure 2-4).

Trams in the southeastern Pennsylvania region are known as trolleys. Trolley service to Chestnut Hill began in 1894 and today, two SEPTA (Southeastern Pennsylvania Transportation Authority) Regional Rail lines as well as several bus routes serve this town. The center of the town, where trolleys once ran, is the place for feature shopping, antiques and dinning of all sorts as well as walk-ability and charm ("chestnut hill local"). Chestnut Hill offers a vibrant commercial main street, low-density diverse housing stock including multi-family, townhouse, and detached houses, and a strong community commitment to lifestyle worth preserving (Sloan, 2012).
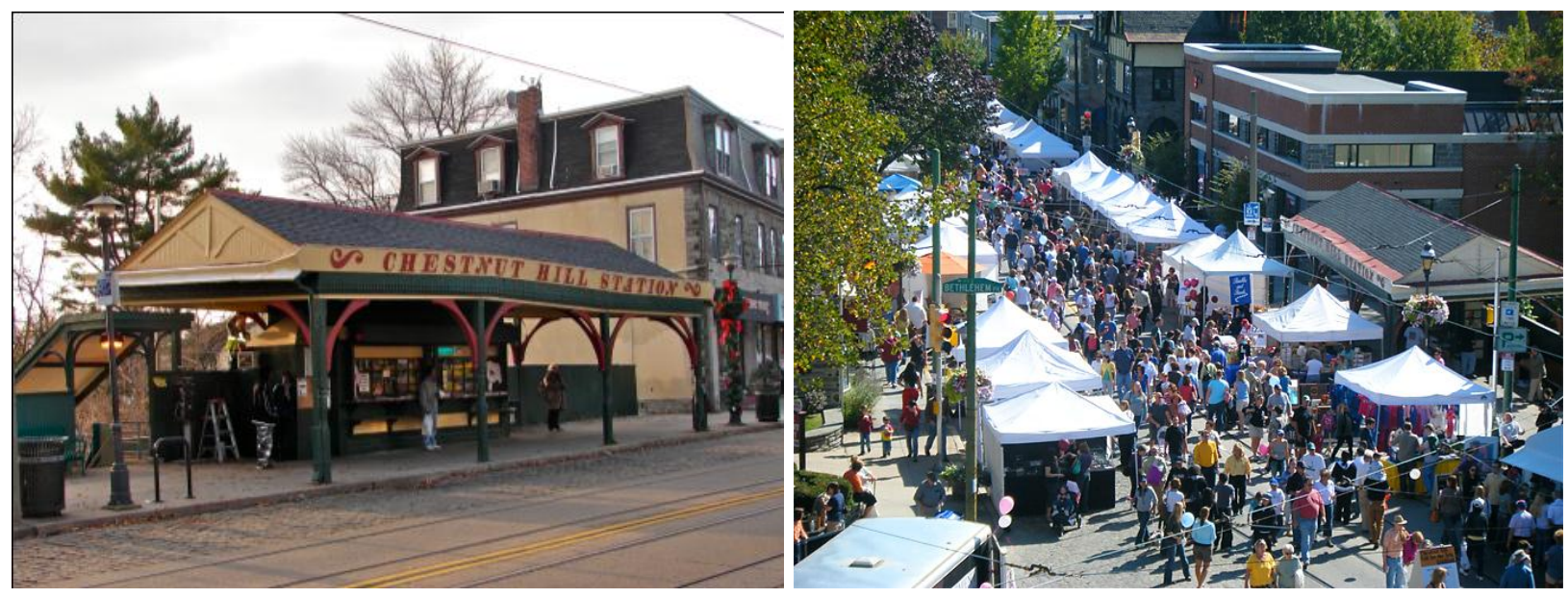

Figure 2-4: Chestnut Hill, Philadelphia: Rail station (left) and vibrant commercial main street (right) Source: Wikipedia, 2014 and www.uwishunu.com 


\section{Chapter 3 TOWN OF MOUNT ROYAL, A MODEL CITY AND AN EARLY TRANSIT-ORIENTED DEVELOPMENT}

This chapter introduces Town of Mount Royal as a proper example of an early suburban community, which was developed around a major transit line in Montreal. The design genesis of the Town and the Mount Royal tunnel as a marvelous construction are explained. Then, an overview of the development stages as well as the role of municipality, transit authority and the developer is presented. The chapter concludes with lessons learned from Town of Mount Royal as a transit-oriented development.

\subsection{Town of Mount Royal: A Hundred Years of History}

The Town of Mount Royal (abbreviated TMR) is an independent suburb of Montreal that was created on the initiative of the Canadian Northern Railway $(\mathrm{CNoR})$ on the northern boundary of the city in the early 1910s (CanU, 2014). It was Frederick Gage Todd (1876-1948), often considered Canada's first landscape architect, who developed the plans influenced by the Garden City and the Garden Suburb movement in Great Britain as well as the City Beautiful Movement in the United States. The town was officially incorporated on December 21, 1912 and celebrated its centennial in 2012 (Ville de Mont-Royal, 2014).

Initially the Town was created to finance the construction of a three-mile tunnel called Mount Royal under the mountain to downtown Montreal (Stern, Fishman \& Tilove, 2013). This doubletrack rail tunnel was built by the $\mathrm{CNoR}$ as a means of gaining access to Montreal for its passengers' service (Kalbfleisch, 2013). The Canadian Northern Montreal Land Company (Land Company) also capitalized on this convenient method of transportation giving the Town a great 
opportunity to take advantage of the tunnel at the same time (Montreal Gazette, 1918). The train runs from central station in the heart of Montreal through a bore of 16,315 feet long. At the north portal the rail right-of-way enters the Town and bisects the residential area. Train schedules at peak periods provide a ten-minute running time and offer convenient transportation between TMR and downtown Montreal (Kalbfleisch, 2013).

\subsubsection{The Development Context}

At the turn of the twentieth century, the Industrial Revolution was in full swing in Canada. New technologies like the automobile and the airplane were expanding the capacity of the economy. Perhaps the boldest company in the nation at that time was the CNoR which was established by Sir William Mackenzie and Sir Donald Mann in 1899 (Wikipedia, 2014). The founders succeeded in the great project of creating a transcontinental railway in which the last and most difficult step was to establish the terminus in Montreal. In eastern Canada, between 1908 and 1911, several lines were built that connected Toronto, Ottawa and Montreal to each other. In 1912, when Grand Trunk Railway (GTR) and Canadian Pacific Railway (CPR), competitors of CNoR, were holding the ideal southern routes around Mount Royal to downtown Montreal, CNoR started building a double-tracked mainline north by building the Mount Royal Tunnel under the mountain.

Besides being Canada's largest city, Montreal was its financial, manufacturing, and transportation center as well (Wikipedia, 2014). Between 1900 and 1910, as foreign newcomers, migrants, and others took up in both urban and rural areas, city's population grew by some $47 \%$, and suburban neighbors at even higher rates (McCann, 2010). To accommodate this population surge, there was tremendous speculation in land and investment in the construction of houses. In 
the few years before the war-associated collapse of residential construction in 1914, the City of Montreal started to build new dwellings several time more than the amount of any year in the previous decade. This housing boom sparked the spatial expansion of greater Montreal in all directions, but the advance was easier along the terraces paralleling the Saint-Lawrence River (Choko \& Harris, 1989) (Figure 3-1).

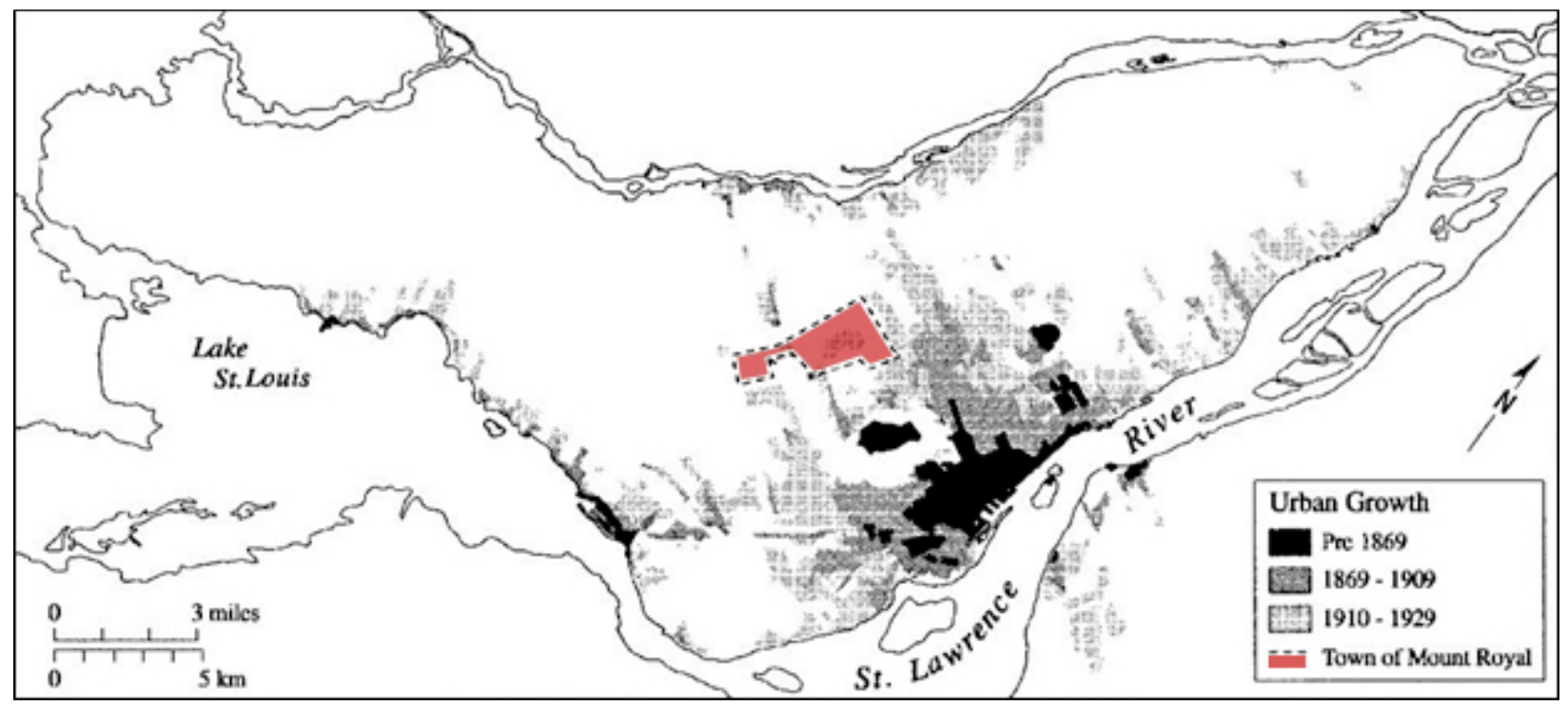

Figure 3-1: The spatial pattern of urban growth in the Montreal area Source: After 1957 Atlas of Canada, 3rd edn.

Despite aid from some scattered suburban rail and tram lines, access to the plateau, slopes, and plains lying to the northwest and beyond the mountain remained difficult in pre-war Montreal (McCann, 2010). Montreal was the fastest growing major city in North America and because of its spectacular development it was impossible for the railway to enter Montreal from either the east or the west. The city was too developed. Furthermore, the Saint Lawrence River and Mount Royal Mountain barred entry from the south and north respectively. Therefore, the developers opted for an exorbitantly expensive but practical solution to tunnel under Mount Royal (Figure 32). 


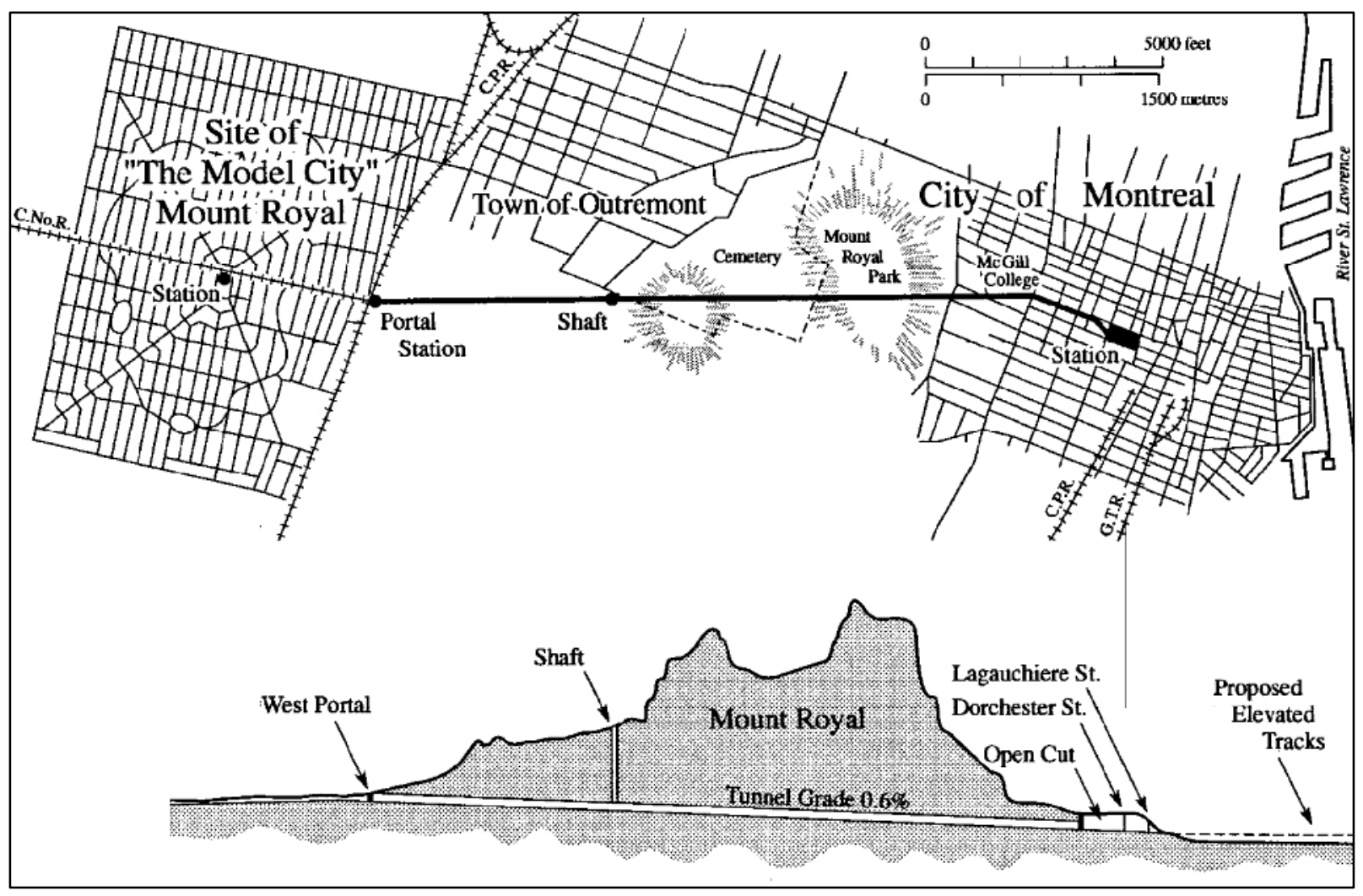

Figure 3-2: Town of Mont Royal in relation to Mount Royal Tunnel and central business district of Montreal, 1912.

Source: The Cartographic and Architectural Archives Division, National Archives of Canada.

To defray part of the projected twenty-five million dollar cost of the project (which included a tunnel, bridge, elevated line, central station, hotel, real estate, hanger, and shops) the railway decided to develop a residential suburb north of the mountain (Kalbfleisch, 2013). They realized that this inaccessible land would become prime real estate after the mountain was pierced. Accordingly, they purchased huge tracks of land and delegated Thomas Darling ${ }^{3}$ to be responsible for its development.

\footnotetext{
${ }^{3}$ Thomas Stephen Darling (1881-1952) was Town of Mount Royal's first mayor from 1913 to 1934.
} 


\subsubsection{The Transition from Farmland to Townsite}

The property purchased by the $\mathrm{CNoR}$ was situated to the north of Mount Royal Mountain on a rich agricultural plain dotted with farmhouses and barns (Jacobs, 2012). The site was almost perfect for development. Only twenty-five farmers owned the land, and there were fewer than fifty-five buildings on the site (Kalbfleisch, 2013). The majority of these structures bordered Cote-de-Liesse to the north, while a few were located along the CNoR line. Furthermore, the land was almost completely flat with an ideal slope of one percent. Finally, the soil was very fertile and the region was famous for their Montreal melons. So special was the Montreal melon that it was exported to New York, Chicago and Boston, where, in 1921, people paid as much as $\$ 1.50$ a slice to taste it (Ville de Mont-Royal, 2014). Farming was abandoned over the years, with the gradual urbanization of the Town. The soil was very fertile as well as ideal for construction and excavation. Considering all these factors together, the developers were not exaggerating when they claimed in a 1912 brochure that there was "not an undesirable lot in all of Mount Royal" (Figure 3-3).

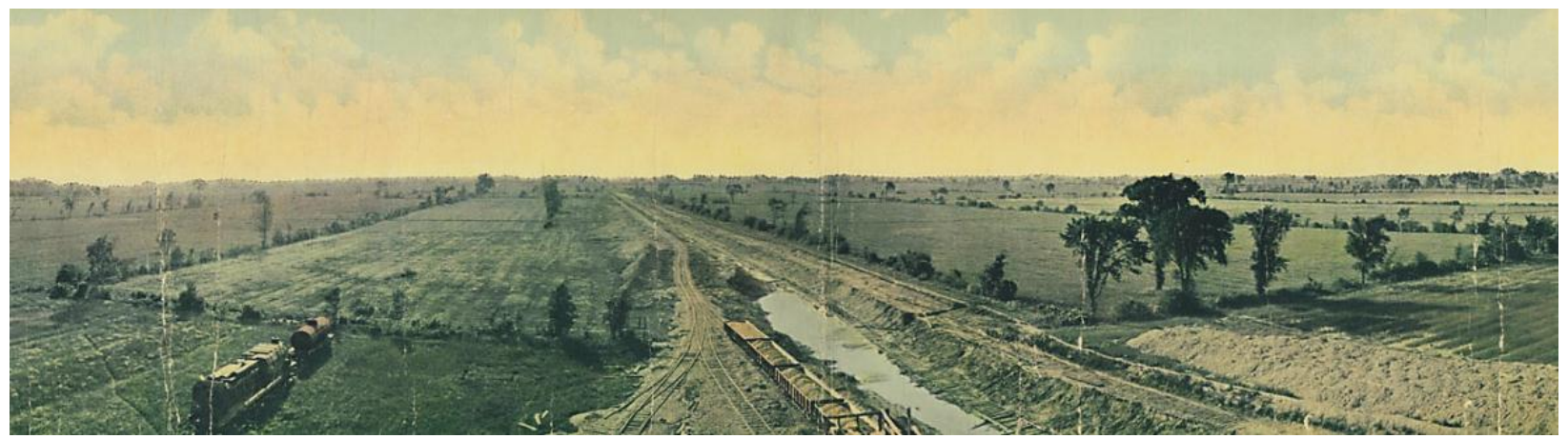

Figure 3-3: The land was previously a farmland Source: The Canadian Northern Montreal land Company, Limited, n.d. 
In the early years of the $20^{\text {th }}$ century there was a good deal of optimism for the future of Montreal (Jacobs, 2012). During a visit to Montreal in September 1911, Mr. Allan Barker, a Member of Parliament from London, England observed that:

"Cheap fares and well developed suburbs had wrought a marvelous change in the over-crowding of some parts of that great city. If the railway gives a cheap fare and rapid transit, the new city (Mount Royal) will be a genuine boon to every class of citizen. It is simply impossible to overestimate the value of a home away from the crowding and bustle of the city, and he was confident that the new suburb would (not) only be a financial success for its owners, but would add greatly to the general health and happiness of the citizens".

It is actually perceived from the newspapers of the time that the sale of building sites for the new development was considered as an obvious financial opportunity in a splendid environment conveniently located close to the city core without any of the problems associated with the noisy, crowded, and somewhat polluted industrial city center of Montreal (Jacobs, 2012).

"No need to be a prophet to predict the future of such an ideal place like "Mount Royal" Model City. Montreal is definitely one of the most congested cities in the world for its size where the mountain blocks its natural development. The Mount Royal tunnel would disappear this barrier and place the citizens of the Town closer to the center of metropolis than anywhere else in the Great Montreal ... "A residence in Mount Royal would provide you a happy, comfortable, healthy life in pure air ... no more delays to get to your business when the snow and traffic

\footnotetext{
${ }^{4}$ Montreal Weekly Witness; 26 December 1911, p. 15.
} 
blocking the surface tramways. By this tunnel, in $7 \frac{1}{2}$ minutes, you will arrive in the city in fast trains which are comfortable and powered by electricity."

The Town in all respects was a suburb when founded in 1912. Communication to and from Mount Royal was limited to the rail tunnel and to two paved roads at the south-east and southwest corners (Graham and Laird Boulevards respectively) (Ville de Mont-Royal, 2014). The Town grew slowly in its early years and did not show signs of approaching maturity until after World War II, when the pressure of an increased population in the greater Montreal and its (by then) strategic location, caused it to attract many residential newcomers. Gradually the population of greater Montreal grew around its central mountain and surrounded the Town of Mount Royal. As better road facilities became available the value of the Town's unoccupied land became apparent, both for residential and industrial developments.

After WWII the Town was faced with an accelerated residential building program and the concurrent need to provide services in the form of sewers, water, roads, street lighting, snowremoval, and street-cleaning (McCann, 2010). The advantages of broadening the tax base were then evident and the development of an industrial area became attractive to the Town's authorities. Other organizations interested in the industrial development field also realized the advantages of the Town's location for light manufacturing, warehousing and distribution operations and became active in its development.

\subsubsection{The Design Genesis of the Model City}

As highlighted by McCann (2010), Mount Royal was not created in isolation and its design concept, as an ideal suburb, comes from convergence of ideas including Anglo-American

\footnotetext{
${ }^{5}$ Publicite paru dans La Presse, 12 April 1912, p. 10.
} 
influences on town planning in early twentieth-century Canada. To this end, several international planning experts, including the famous landscape architect and planner Fredrick Law Olmsted, Jr and Henry Vivan, a British advocate of housing reform and garden suburbs, visited Montreal in the summer of 1910. They exchanged ideas with people about the role of modern city planning which then forced some critical thinking about traditional ways of improving the metropolis.

The Province of Quebec Association of Architects (PQAA) issued several City Beautiful proposals on parks and boulevard development for Montreal against which Olmsted was highly critical (McCann, 2010). PQAA proposed to relieve downtown traffic congestion by constructing diagonal boulevards that sliced through the central business district but, Olmsted conversely argued that construction of radial or diagonally-placed thoroughfares in advance of suburban development on the northwest side of Mount Royal would facilitate orderly growth there.

Olmsted's proposals were never introduced officially into a city plan of any kind. But the 'platform' and 'planning process' he advocated influenced the design, planning and subsequent development strategies used by the Land company in building the Town of Mount Royal (Cooper, 1969).

By Christmas of the year 1911, the press announced the building of a 'ville-modele ou villjardin'; however, the town was later referred to as 'Mackenzie Heights', taking its name from the President of the CNoR (McCann, 2010). Later, in April, when town lots were first sold to the general public, the Land Company's promotional literature headlined 'the Model City of Mount Royal - An Ideal Residential District'. Land Company officials went so far as to hail Mount Royal as a "Garden City in the very best sense of the word" (Canadian Northern Montreal Land Company, 1912). 
The Town is continually described as a hybrid of the Garden City and the City Beautiful movements as influenced by l'Enfant's plan by Washington, D.C. ${ }^{6}$. These arguments, however, are not particularly convincing (Jacobs, 2012). The Garden City movement was conceived as a social project to support relatively self-sufficient communities that included working, recreation, and residential facilities separated from major metropolitan communities by green belts. Two examples of the Garden City movement in England before and just after the First World War are Letchworth Garden City (1904) and Welwyn (1919) respectively (Figure 3-4).
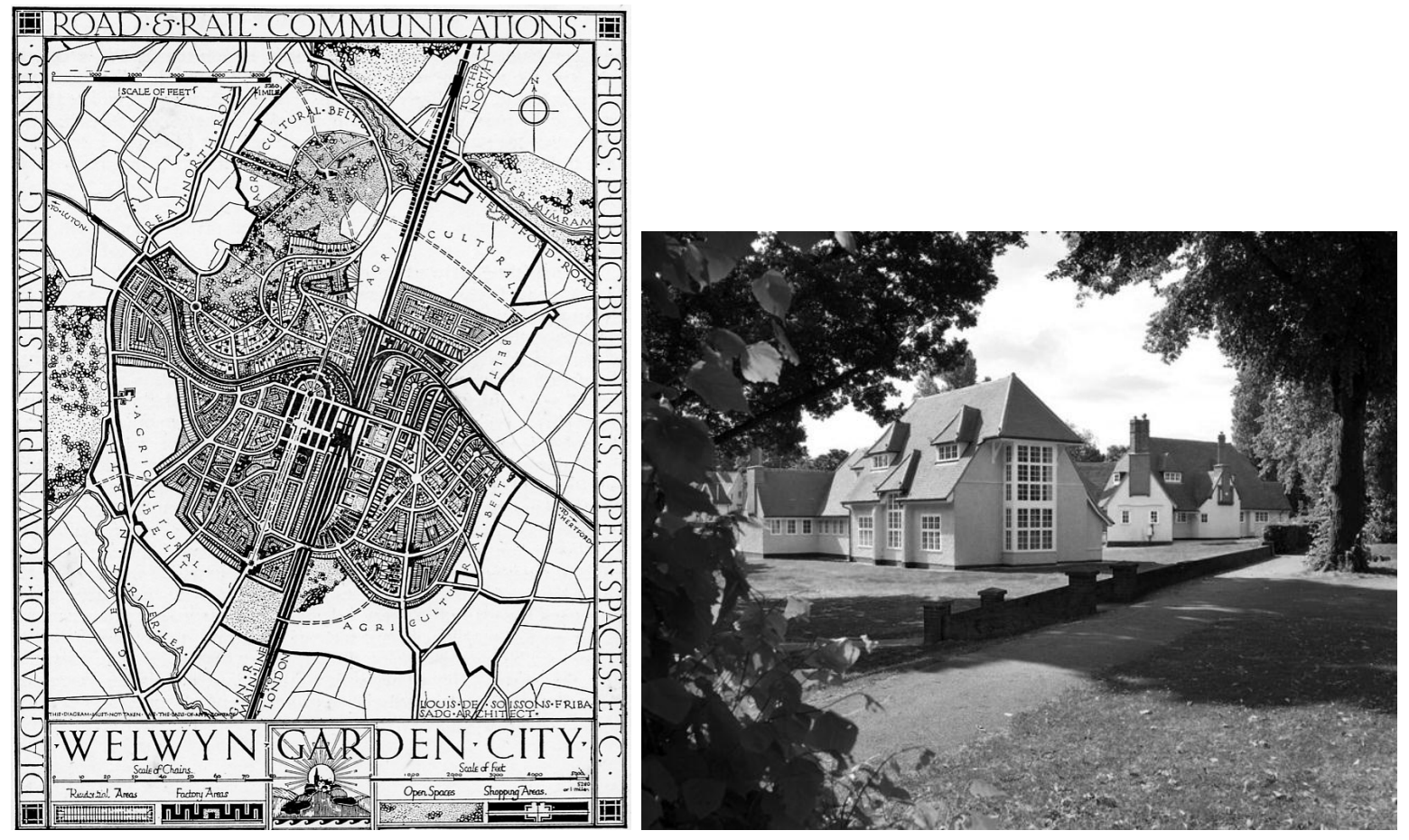

Figure 3-4: Welwyn (Left) and Letchworth (Right) Garden Cities in England Source: www.google.com/Welwyn \& www.google.com/Letchworth

What Ebenzer Howard proposed was beyond the simple desire for comfort. It involves the social factor, human and community. In general, the plan proposes a circular structure in which the center is more densely built and this density decreases as you get closer to the outskirt of the city

\footnotetext{
${ }^{6}$ The L'Enfant's plan of the Washington, D.C., is the urban plan developed in 1791 by Major Pierre Charles

L'Enfants for George Washington, the first president of the United States.
} 
to achieve a reserved space in nature. His model includes industrial, commercial, fields, greenery, houses of any kind for everyone. This is more than a dormitory town, a real selfsufficient system of social organization, or cooperation is required ${ }^{7}$ (Figure 3-5). $^{2}$
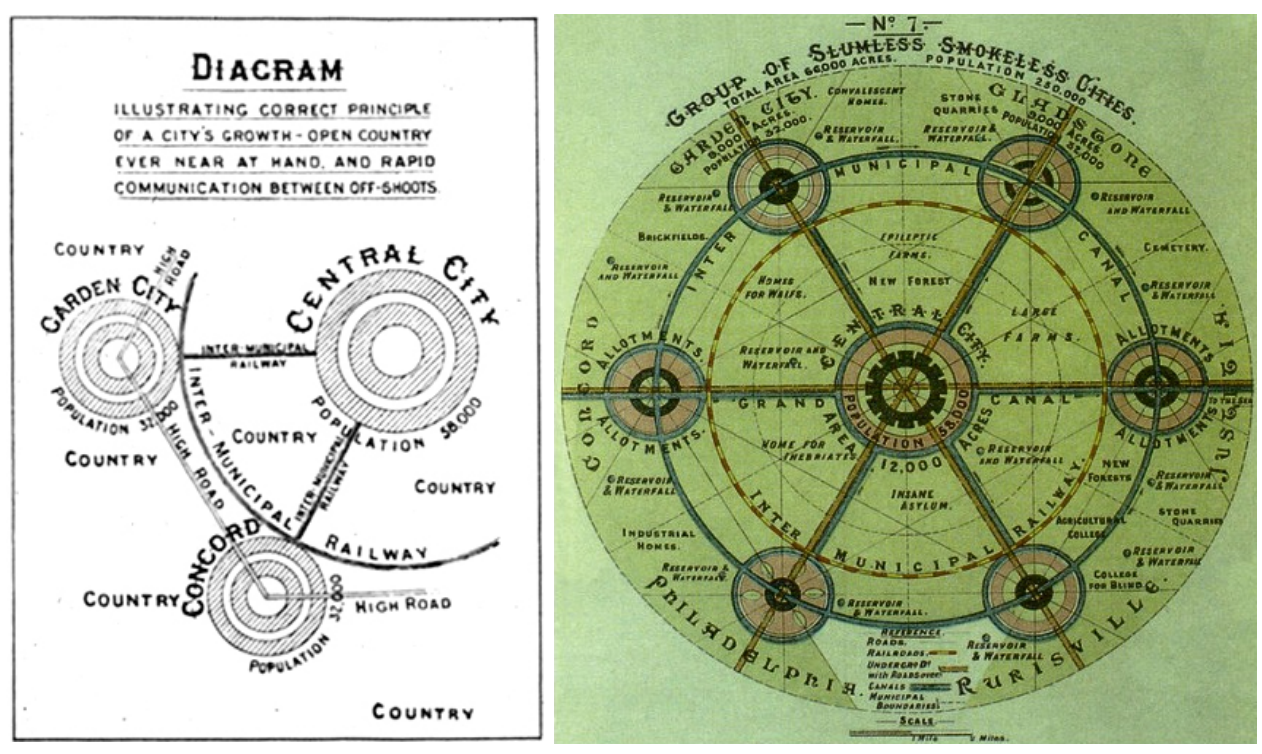

Figure 3-5: Garden City Diagram

Source: Diagram originally published in Ebenzer Howard's "Garden Cities of Tomorrow", 1902

City beautiful advocates intended, by contrast, to introduce beautification and monumental grandeur in cities whose beauties would inspire loyalty and moral attitude in the impoverished areas. The movement was originally associated with Chicago, Cleveland, Detroit, and Washington, D.C. (Bluestone, 1988). Advocates of the philosophy believed that such beautification could promote a harmonious social order that would increase the quality of life. A more inviting city center still would not bring the upper classes back to live, but certainly to work and spend money in urban areas (Jacobs, 2012).

Although some of the spatial ideas of the Garden City and City Beautiful movements can be found in the layout of the Model City, neither provides a convincing explanation of the layout

\footnotetext{
${ }^{7}$ P94 Lexique, Les Cites-jardins. Trans.
} 
that emerged in 1914 (Jacobs, 2012). The more obvious and influential precedent designed by Olmsted in 1877 is the community of Riverside located some 6 miles outside Chicago. The community is served by a railway line which brought about a significant housing and construction boom in what was once farmland far from the bustle of the city of Chicago (Wikipedia, 2014). This exurban residential suburb which was structured along the network of railroad lines increasingly marked the landscape of North America.

Riverside was a masterful proposal with greenways and pedestrian circulation radiating out from the railway station to all corners of the residential community (Jacobs, 2012). The town's plan called for curvilinear streets, following the land contours and the winding path of the Desplaines River. It also accorded for a central village square, located at the main railroad station. The community, like that of the Model City, was intended to maximize the benefits of living in a low density natural setting while simultaneously enjoying close proximity to the center of industry and commerce that lay but a few miles distant by rail (Wikipedia, 2014) (Figure 3-6).
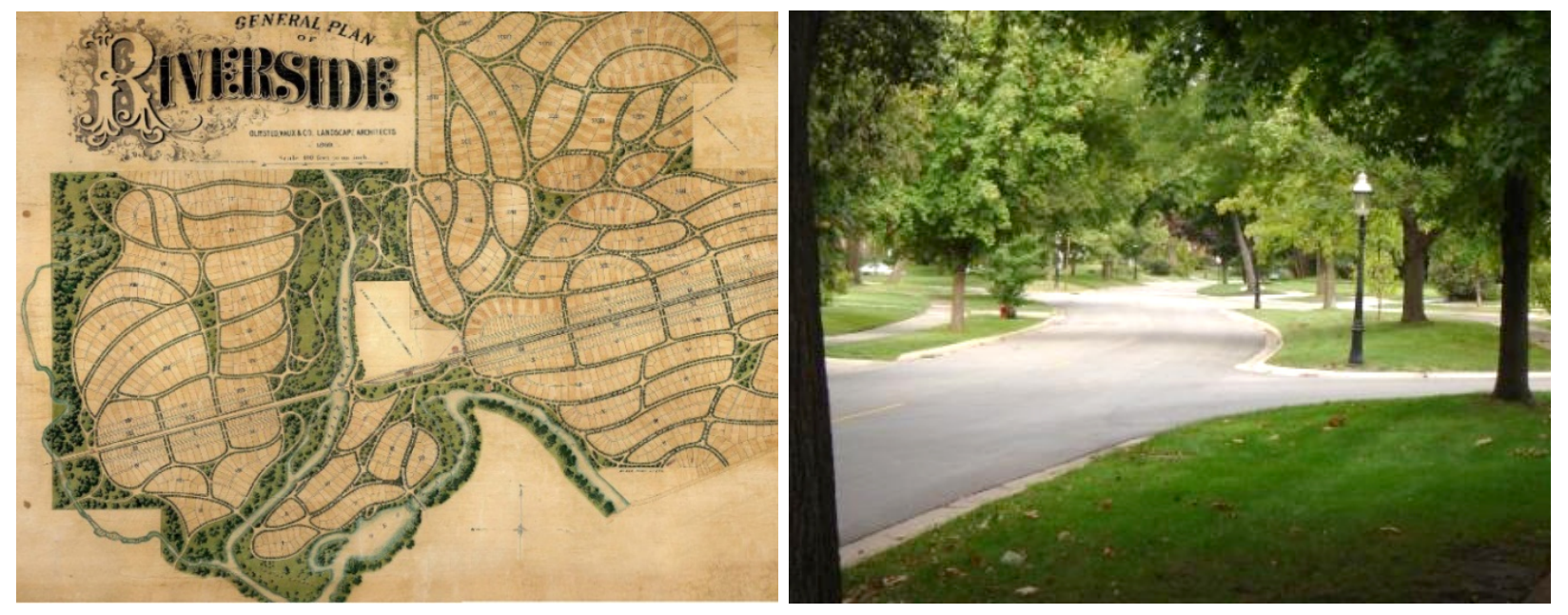

Figure 3-6: Riverside, Illinois, F. L. Olmsted \& Vaux, 1877

Source: http://www.fredericklawolmsted.com, 2011 
The urban plan of Washington, D.C., with its elaborate thoroughfares laid out along Baroque and City Beautiful lines, was also cited as the inspiration for the particular design feature implemented in TMR ( $75^{\text {th }}$ Anniversary Souvenir Booklet) (Figure 3-7). The diagonal boulevards of Washington, D.C., cutting across the residential area were used as a model in the plan of TMR and while much of the Town was developed according to this plan, various alternations were made over the years, particularly with the creation of crescents rather than straight streets on the northern end of Laird Boulevard and the area north of the western part of Graham Boulevard.

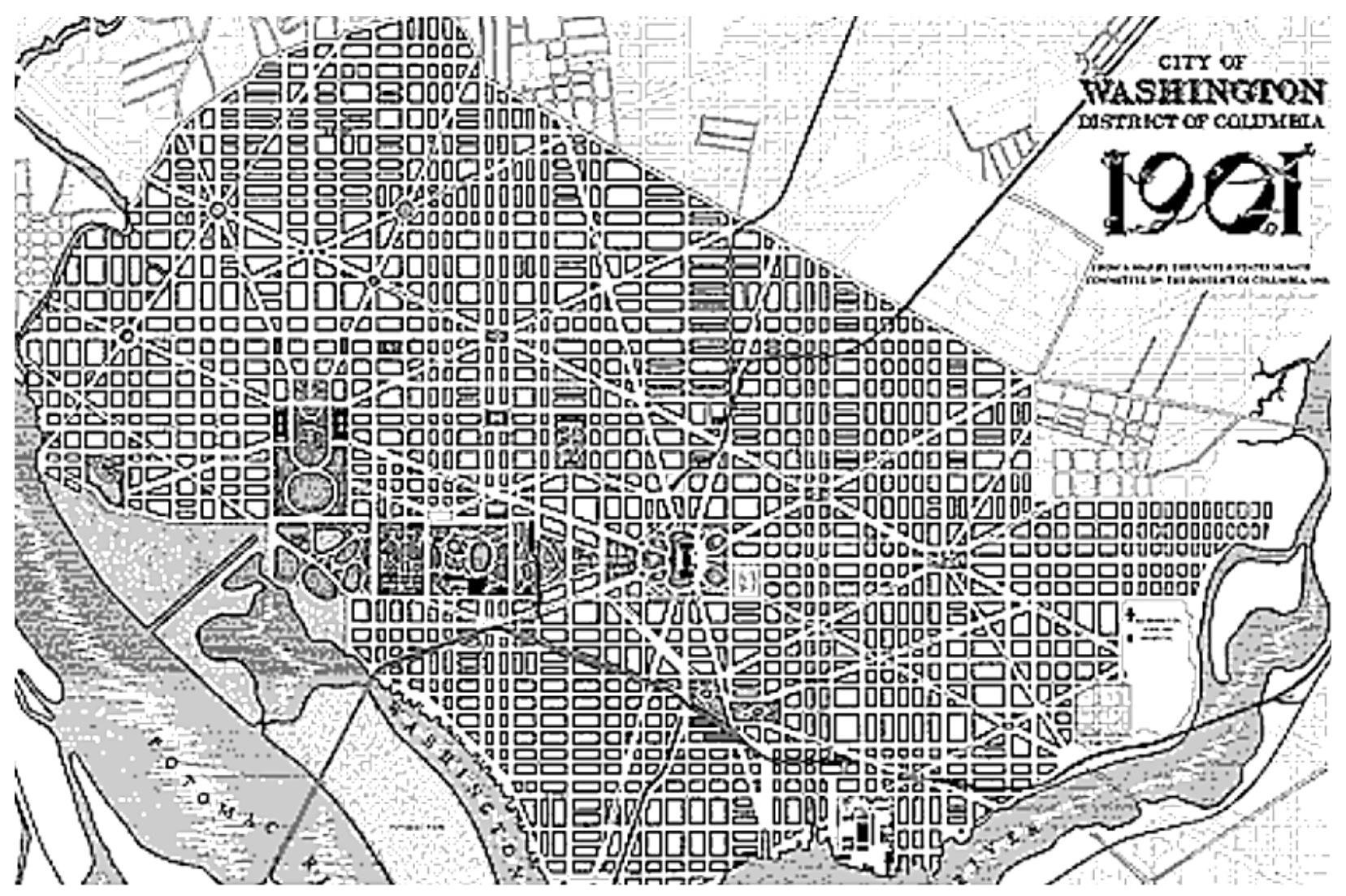

Figure 3-7: The L'Enfant Plan for Washington, D.C.

Source: Wikipedia, 2014 
From all these perspectives, Mount Royal represents a situation where ideas converge to form a new and separate reality - the first major planning project in Canada to blend some of the competing principles of the City Beautiful, Garden City and Garden Suburb movements to build an ideal suburb.

\subsubsection{Men in Charge}

\section{- Thomas Stephen Darling}

If there is any one person that could be called the "Father" of the Town of Mount Royal it is undoubtedly Thomas Stephen Darling. Darling joined the Canadian Northern Railway in 1907, where he worked successfully for the Department of Immigration and Lands Sales (Ville de Mont-Royal, 2014). In 1911, having the mandate to establish the Model City, he bought ail and land necessary for the development on behalf of the Canadian Northern Montreal Land Company and later coordinated the railway's land purchase for its downtown central stations. On February 16, 1912 when Todd's plan of the Town was first published it was stated that he had worked under the direction of Darling and some Todd's preliminary plans had been rejected or been ordered to be revised or improved by Darling (McCann, 2010). He also did some preliminary improvements to the site, such as the construction of the Graham Boulevard. In January 1913, he was elected as the mayor and served as mayor for twelve consecutive terms, until 1934. Upon his death in1952, the Weekly Post eulogized that "All those who are privileged to live in the Model City which he founded and tended are indebted to this man, who envisioning an ideal, never faltered in its creation". In fact, without Darling's vision and commitment to the Town, it is quite likely that uniformity of purpose in developing the Town would have been lost (McCann, 2010). 


\section{- Frederick Gage Todd}

The idea for the town emerged as a speculative residential scheme at the height of the pre-First World War land boom (McCann, 2010). The City Beautiful ideas of Frederick Law Olmsted, Jr and the Garden Suburb principles of Henry Vivian were introduce to Montreal in 1910 and one year later their ideas and other planning models converged and were incorporated to form the unique design by Frederick Todd (Figure 3-8).

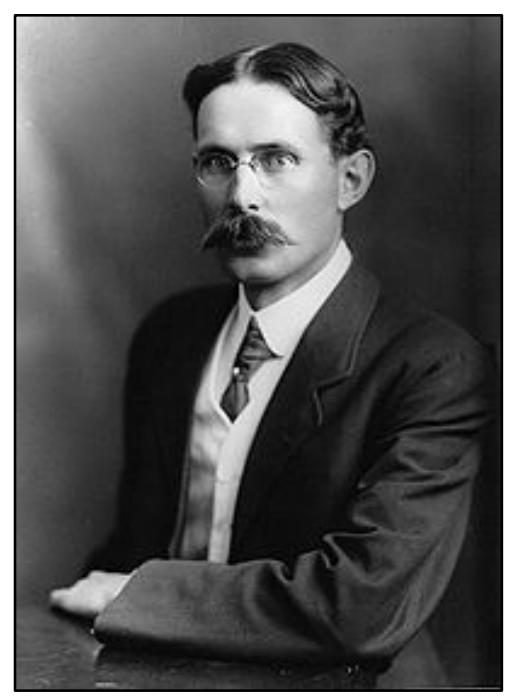

Figure 3-8: Frederick Gage Todd Source: Wikipedia, 2014

Born in New Hampshire, Todd was Canada's first professional landscape architect. He had apprenticed in the Brookline, Massachusetts office of Olmsted, Olmsted and Eliot during the late 1880s, before moving permanently to Montreal in 1900 to complete work on Mount Royal Park and to develop his own practice (Jacobs, 1983). Todd was one of Canada's leading landscape architects with a recognized ability for improving upon poorly-conceived urban plans, making them more attractive and profitable (McCann, 2010). The ongoing struggle to implement the initial design for Mont Royal Park, initiated in 1874, brought Todd to Montreal (Jacobs, 2012). 
For more than 40 years he stayed in Canada and designed many of the most important public, institutional and private landscapes. It is not known precisely, however, when or how Todd was hired to work on the design of the Town of Mount Royal, nor the specific instructions he was given by the Land Company to improve upon Thomas Darling's 'grid and diagonal' plan (McCann, 2010).

In 1911, Todd was approach to developed and improve Darling's initial sketch (Jacobs, 2012). Being a pragmatic professional informed by principles of landscape design, Todd's philosophy was strongly associated with the beauty of nature, the imperative to wisely use the resources that nature provided, while addressing human needs of a growing urban population across Canada.

\subsubsection{The Design Stages of the Town}

The design of the Town of Mount Royal revolves around three plans (Jacobs, 2010). The first is a reproduction from the photographic archives of the CNoR which is attributed to the Chief engineer of this company, Henry Wicksteed. There can be no doubt that this plan was drawn in summer 1911, when the CNoR purchased the downtown properties, and then to a diagrammatic layout by Thomas Darling and finally on February 1912, to a more fully developed and radically different design of a "Model City" by Frederick Gage Todd.

By the spring of 1911, Mackenzie and Man who capitalized on this experience, decided upon the best route for tunneling under Mount Royal. However, from a planning point of view, the quality of initial plans was not matched with the boldness of this decision - that is little evidence of nnovation in either the "grid and diagonal"8 conceptual plan (A) or the even cruder "diagonal cross" diagram (B) (McCann, 2010) (Figure 3-9). While being schematic and even rudimentary,

\footnotetext{
${ }^{8}$ This plan was sketched by Thomas Darling of the Land Company in the summer of 1911.
} 
these two preliminary drawings are in some points informative: The first point is the use of a long-established design for laying out railway towns in North America and the second point focuses on how patterns of land acquisition which are affected by the local context of physical, cultural, and market conditions, can influence the size, shape, and layout of a town (McCann, 2010).

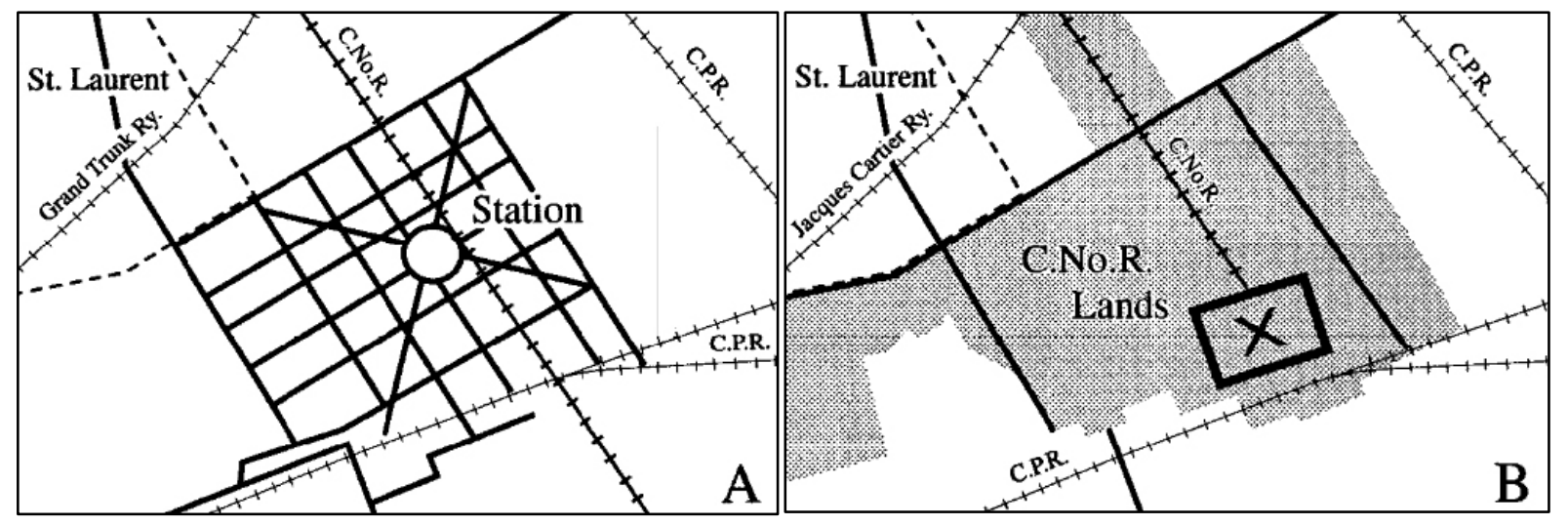

Figure 3-9: Preliminary plans for the layout of Town of Mount Royal Source: Architectural Archives Division, National Archives of Canada

All subsequent designs for Mount Royal were based on rectilinear and diagonal street layouts. The gridiron plan was most often used by North American railway companies when planning and developing towns along their routes. The reason for imposing diagonal boulevards over this grid is to focus on the railway station by lying adjacent to a central and circular roundabout (McCann, 2010). In this way, an easy and rapid access to the train station is provided from any point.

There are three idiosyncratic ideas about the use of radial street pattern (Calthorpe, 1993). First, a diagonal is the shortest distance between two points and that is important to the person on foot. Retail and transit as the prime uses at the core of a neighborhood are essentially nodal and do not 
function well in a linear form. Second, this particular type of design helps distinguish "civic" roads from neighborhood streets and, finally, it highlights the identity of the center.

In February 1912, the official plan of the Model City sketched by Frederick Todd was announced in La Patrie newspaper (Figure 3-10). Comparing to the previous 'diagonal cross' map of the town, this plan confirmed the intentions of the railway to transform the rural landscape of the Island of Montreal into a stronger urban reality. The town had a distinctive shape and it was larger than any previous suburban endeavor on the Island. The crossing diagonal streets remained. Widened to 80 feet, these were now more clearly defined as boulevards, compared to the 66 feet residential streets. The railroad, which bisected the town, also confirmed. The pattern of streets, aligned to the cadastral system, was the typical format of Montreal's speculative, suburban frontier (McCann, 2010). What was unusual about the layout of these blocks, was Todd's placement of the extended length of blocks in a north-south direction, not east-west, thereby exposing more houses to the sun for longer periods of the day. Within these blocks, lots were quite generous in size when compared to other suburban developments. Todd also changed the central circle to a three-part, oblong-shaped town center, similar in design to Letchworth. Like the circle, it was placed where the diagonal boulevards met in their attempt to cross the CNoR's main line. The idea of radial scheme with four boulevards converging into a roundabout was to permit fast and direct access from the outskirts of the property to the commuter railway line, as well as to provide a suitable back drop to the railway station. The intention to house several public buildings beside the railway station is also visible.

The most Todd's striking and original addition to the plan, which was a unique feature in the design of the Canadian towns, was an elliptical driveway and a park system (thirteen small parks) that meandered through all quadrants of the town resembling a green necklace (McCann, 
2010). Situated about one-half mile from the town center, the driveway crossed the diagonal boulevards at right angles, just as the north-south running streets did. The particular method of turning each cross street into a short diagonal where it met the boulevard introduced a 'new town-planning principle' (Wright, 1938).

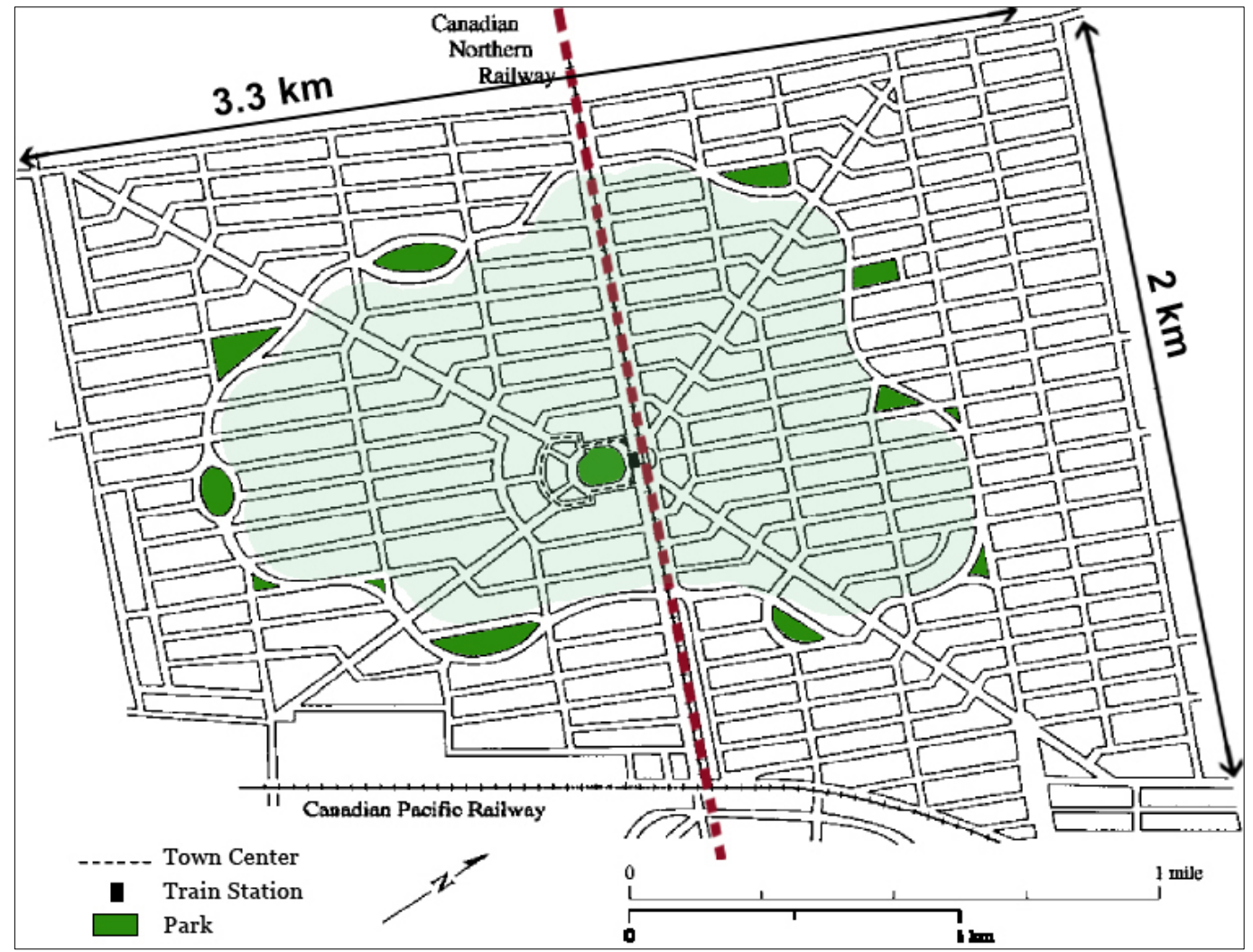

Figure 3-10: The official plan of the Model City established by CNoR Source: La Patrie (Montreal), 16 February 1912, p. 12.

The size of lots, typically measuring 50 feet by 100 or 110 feet, allowed ample space for a single-detached dwelling set within a garden, or for semi-detached cottages stretched across two lots (McCann, 2010). Increasing the size of the residential building lots provided large setbacks from the streets in a way that generous lawns and plantings complement the greenery of the streets. To this end, much of the landscape character of the Town resides in the spacious tree 
lined boulevards, the curvilinear streets and pocket parks that complement the more classic street grid pattern (Jacobs, 2012). Finally, his use of several important Garden City and Garden Suburb feature, such as separating functional zones within the town, creating a hierarchy of residential streets, and integrating internal road and external rail transport, added further efficiency to the interplay between land use and transportation.

Todd believed that Town of Mount Royal required "small squares and breathing places situated at various intervals to ... provide a place of rest and recreation for the people in their immediate neighborhood, and to make [Mount Royal] as a whole more beautiful and attractive" (Todd, 1901). The curving path of his driveway also had an economic logic; the residential property subdivided by curving street sells better and for a higher price and similar property divided into rectangular blocks of straight streets (Todd, 1908).

Having all these characters in mind, a question still comes to mind whether there is a particular source for Todd's oval-shaped parks and his meandering street pattern. According to McCann (2010), Todd had been involved in developing a suburban 'villa park' called 'Bowling Green', located about fifteen miles west of downtown Montreal at Pointe Claire (Figure 3-11). Todd's basic style was clearly Romanesque. Just like Olmsted at Riverside he adopted at Point Claire, the best modern English ideas, especially adapted to the property, with winding roads and numerous miniature parks. He promoted Bowling Green as a 'Garden City', ideal for year-round living. The 'home site' was hardly a 'Garden city' but, it was characterized by a system of small parks of various shapes, all connected together by a curving road which had been placed over a gridiron pattern, which in turn conformed to the topography and original cadastral plan of the historic site. In laying out his beautification plan for Town of Mount Royal, Todd took into account these planning tools and site restrictions. 


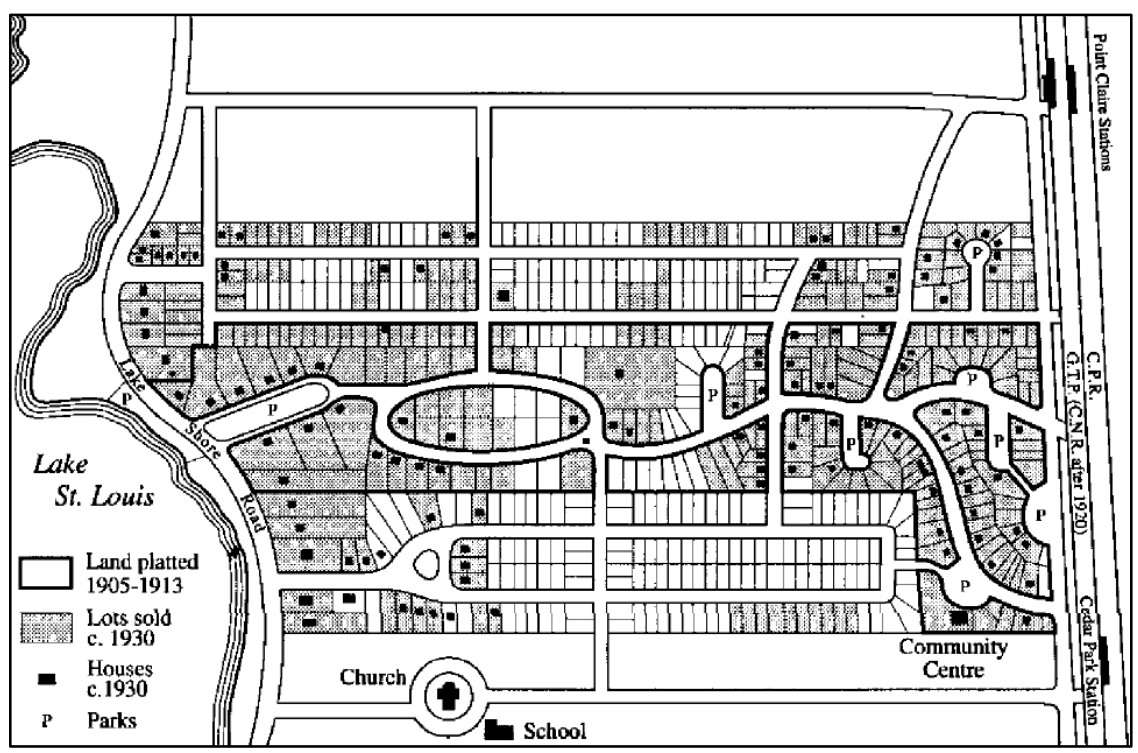

Figure 3-11: Bowling Green, Todd's prototype plan for Town of Mount Royal Source: The Canadian Nursery Company, 1912

The character of Mount Royal's residential districts has been influenced by regulatory bylaws (Canadian Northern Montreal Tunnel and Terminal Company, 1913). According to these regulations the Town's developers intended to attract only the middle class, not the laborer or workman who was seeking refuge from disorder of the inner city. The developers also shaped an urban landscape significant not only for its unity in residential land use, but also for its diversity of housing forms and architectural styles (McCann, 2010). From 1930s to 1960s the dominant built forms were brick, three-storied apartments along Graham Boulevard whereas after WWII, single-detached residences dominated the other major boulevards, less accessible streets, peripheral neighborhoods in the southern, western and northwestern section of the town. The architectural landscape changes closer to the town center. On streets surrounding the town's central square, various public buildings, business blocks, and recreational facilities share space with walk up apartments. 
A general trend that characterized suburban development taking place in Canada after WWI was the planning of modestly-scaled 'Garden Suburbs' which is still remaining in planned suburbs. This feature is revealed in the air photo of Mount Royal in 1924 (Figure 3-12).

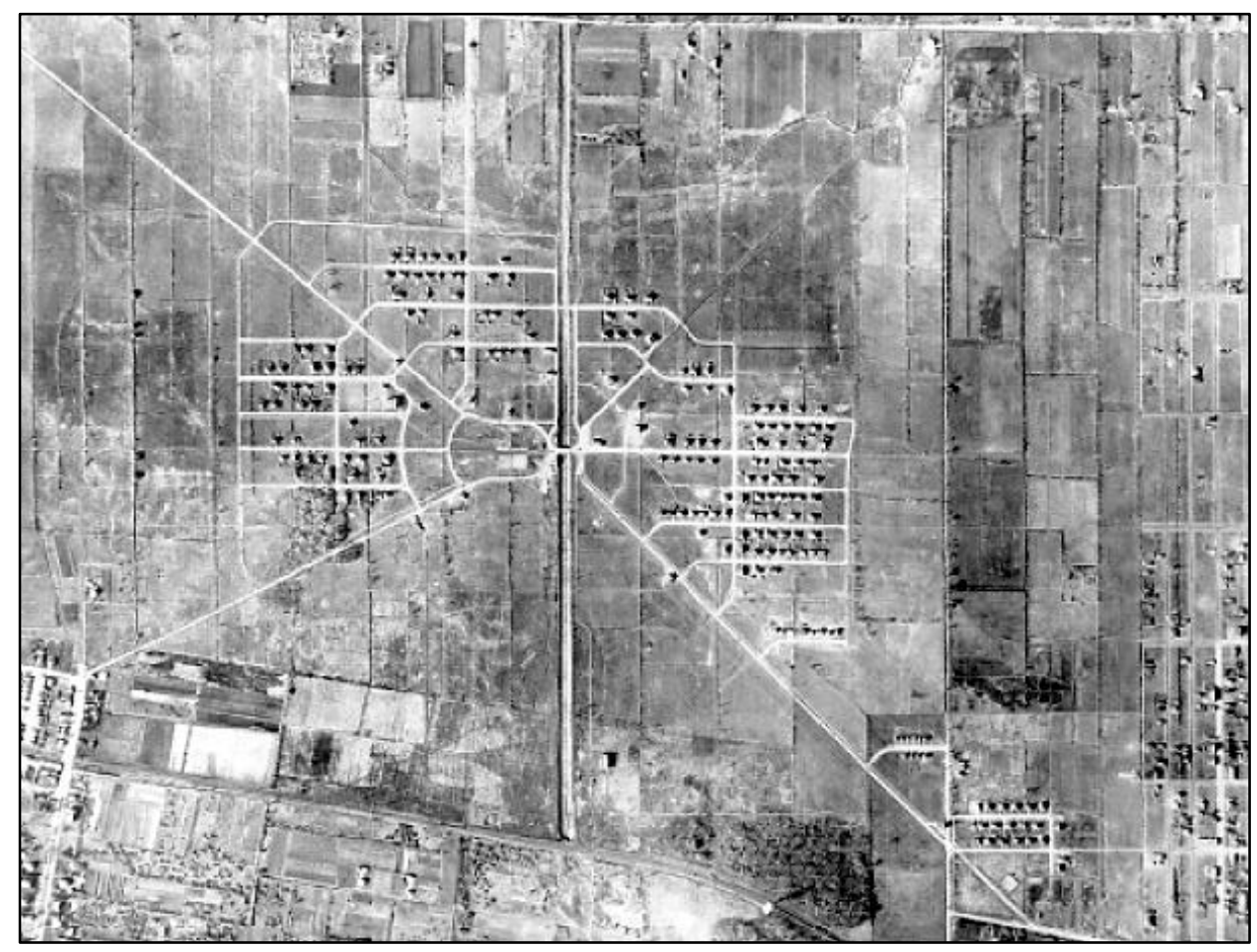

Figure 3-12: Vacant land and the built up area of Town of Mount Royal, 1924 Source: Town of Mount Royal Archives

Overall, when comparing the layout and marketing techniques of several competing subdivisions located within close proximity to Mount Royal townsite, we can confirm the significance of TMR's plan. Furthermore, the Model City was one of the most financially successful and rewarding real estate ventures in Canada at that time (Jacobs, 2012). When compared to other attempts at creating the ideal Canadian suburb, the case of Mount Royal has proven rather unique. 


\subsubsection{Municipality, Transit Authority, and the Developer}

In the spring of 1911, the properties for this suburban scheme (TMR) were purchased by the agents acting on behalf of Mackenzie, Mann and the Land Company (McCann, 2010). Much of the capital used by the Land Company was borrowed from a banking firm that had ties to French and Swiss financial interests. This banking firm stood firm behind the venture, providing additional direct loans and increased their common shares to $75 \%$ after five years. To this end, it was essential to promote the uniqueness of the venture. However, this did not happen until a year after when the Land Company's literature headlined "the Model City of Mount Royal - An Ideal Residential District" (Canadian Northern Montreal Land Company, 1912). Undoubtedly, this version of suburban ideal attracted other investors from across western Canada. The Terminal Cities Company also purchased several lots $(\$ 1.3$ million) along the proposed major and diagonal boulevards of the town where apartments and commercial outlets were planned (McCann, 2010). Mackenzie, Mann and Land Company also facilitated capital formation through taxes on vacant land and developed property, as well as through municipal borrowing privileges to provide infrastructure. The incorporation strategy enhanced long-term plans for meeting debt repayment obligations and for scheduling infrastructure needs for future land sales and residential buildings in the Town. Furthermore, the Land Company maintained its virtual control of TMR's finances and physical planning by acting as the administrator of the Town. From 1912 to 1927, for example, the company rented working space for TMR administrators in its downtown Montreal office. Although the sale of lots was substantial from 1912 to 1913, thereafter the Town entered phases of limited expansion, financial consolidation, and cautious residential growth that lasted through the mid-1920s because of the First World War. 
The first Municipal Council for the Town comprised five Alderman and the Mayor (McCann, 2010). Besides Mayor Darling, the four Alderman as well as the Town's Secretary-Treasurer, A.L. Mackenzie, were associated with the Land Company. Once Mount Royal was incorporated in December 1912, the civic administrators, through various capital-raising by-laws, slowly established an infrastructure of streets (twenty miles of dirt road at first), sidewalks, parks, sewers and water mains; and through protracted negotiations with private and municipal agencies, they signed contracts to provide basic utilities and services. They also wrote by-laws to support the financing of house construction. In 1919, Quebec's strict financial and construction guidelines for housing were set down for the first time (McCann, 2010). Following these guidelines, the municipalities had the opportunity to borrow funds to facilitate house building and homeownership in several key ways: (1) the municipalities could purchase land and build the houses themselves; (2) the individual property owners willing to contract their own houses could receive basic loans from the municipality; or (3) the municipalities could provide substantial funds to bona-fide housing companies which planned to construct the dwellings according to the town's specifications. In the case of Town of Mount Royal, both the Island of Montreal Metropolitan Commission and Provincial Director of Housing were responsible for approval of the housing plan chosen by municipalities including the design, materials, and cost of individual houses.

\subsubsection{Mount Royal Tunnel: A Marvelous Construction}

Just months before the Town was incorporated, in July 1912, the excavation began on what was to become the Mount Royal Tunnel ( $75^{\text {th }}$ Anniversary Souvenir Booklet). After 18 months on December 1913, the two groups of workers tunneling on each side met about 620 feet under the mountain. Even by today's standards, the accuracy with which the tunnel was constructed is 
startling. In February 1916, tunnel excavation was completed and a special test train made its way under the mountain two months after. In October 1918, the first regular passenger train-two baggage and express cars, two coaches, a diner and an observation parlor car made the journey (Figure 3-13). The 'Central Station' also incorporated the largest and most up-to-date railway facility in the Country at the time, and still serves well its purpose to this day (Laurendeau, 2012). There are also some ideas to make this station as part of the metro or the extension of the line to Mirabel airport.
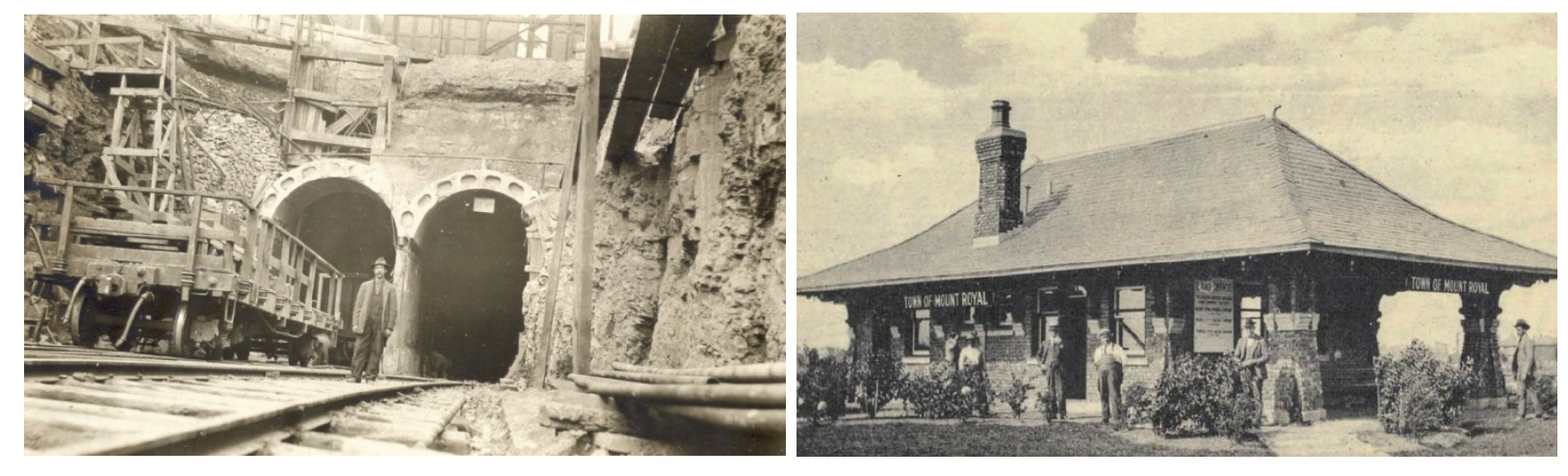

Figure 3-13: Town of Mount Royal Tunnel (left), its station at the Town Center (right) Source: Laurendeau, 2012

The importance of the Mount Royal Tunnel to the Town can't be overestimated. The tunnel placed downtown Montreal just a seven-minute trip away, and that fact alone meant property values in the Town would be substantial. Indeed, the need to finance the relatively high cost associated with the strategy of accessing the city center through this tunnel very much affected the concept behind the purchase, design, and sale of the Model City (Jacobs, 2012). Several Town streets have names related to the railway company and its staff, another indication of the close tunnel relationship. Wicksteed Avenue was named after Henry K. Wicksteed, who first conceived of the tunnel, while Canora road takes its name from the first letters in CAnadian NOrthern Railway ( $75^{\text {th }}$ Anniversary Souvenir Booklet). 


\subsection{Town of Mount Royal, a Model City and a Transit-Oriented Development}

The Ministry of transportation, infrastructure, and communities, informed the City that Mount Royal Model City is a place of national historic significance. From all above mentioned perspectives, there are three key issues that reflect the importance of this designation: the innovative and courageous strategy of accessing the core of Montreal by way of a tunnel under Mount Royal Mountain; the character of its residential and community architecture; and most particularly the unique structure of the community layout (Jacobs, 2012). The Montreal Weekly Witness (1911) has also reported: "it was the first time in Canada that a large suburban area has been designed on the thoroughly scientific and aesthetic lines of modern city planning".

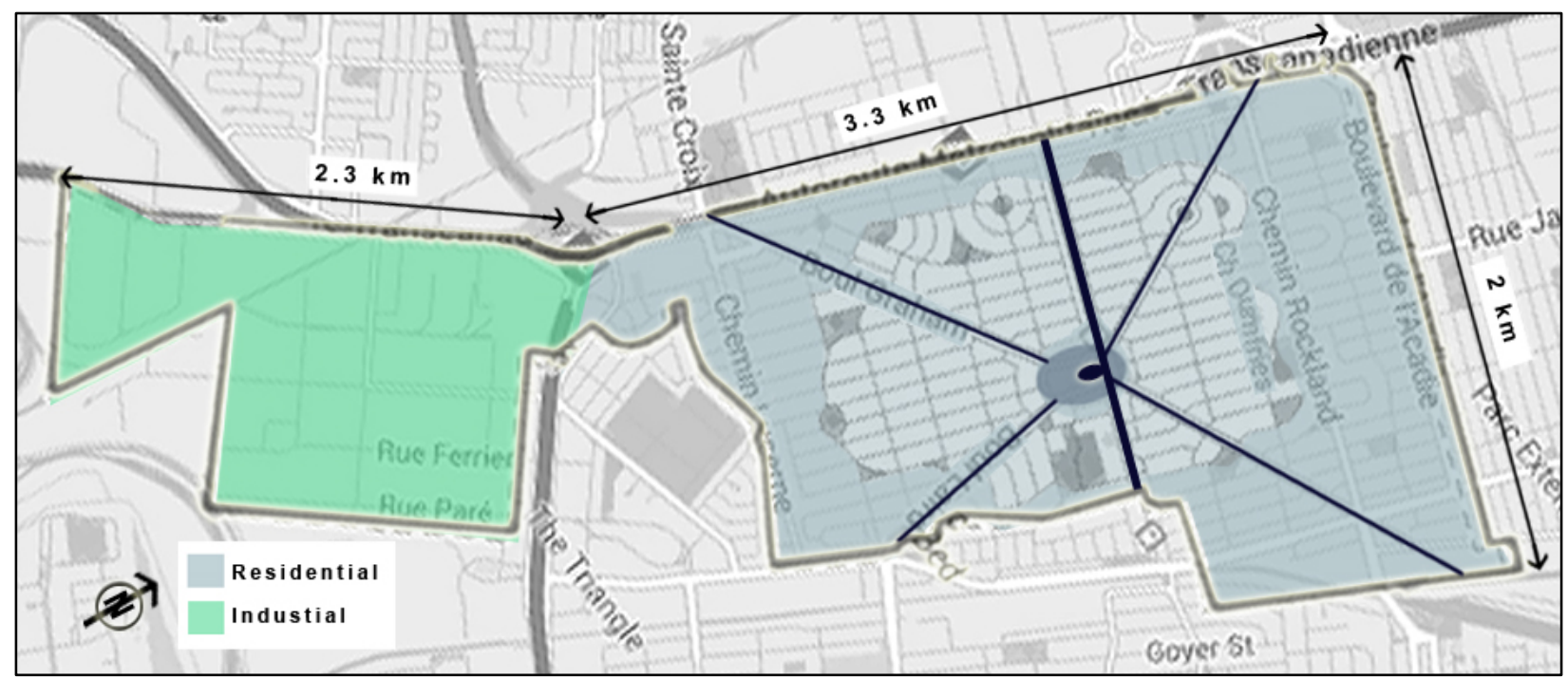

Figure 3-14: Dimensions of the Town of Mount Royal Source: Google Map, 2014

In 1917, with the completion of the tunnel, the town came to life with the population of about 100 people or so and it reached 2000 population with the sounding of peace by the mid-1920s (McCann, 2010). Today, TMR has a population of 20,073 and a surface area of 7.43 square

\footnotetext{
${ }^{9}$ Montreal Weekly Witness, 26 December 1911, p. 15.
} 
kilometers (Gazette Officiel du Quebec, 2014) (Figure 3-14). Both French and English are widely spoken (Ville de Mont-Royal, 2014). In 2008, most of the town was designated a National Historic Site of Canada as a remarkable synthesis of urban movements of the $20^{\text {th }}$ century (Wikipedia, 2014).

\subsubsection{Density, Diversity, and Design in Town of Mount Royal}

According to Calthorpe (1993), TOD residential density requirements should be met with a mix of housing types including small lot single-family, townhomes, condominiums, and apartments. Comparing with typical suburban land use patterns, Town of Mount Royal provides a higher concentration of households in close proximity to the central transit station and core commercial buildings. The Site Planning and Architectural Integration Program (PIIA) (2007) for Town of Mount Royal presents eight styles of houses grouped in three development phases (Figure 3-15).

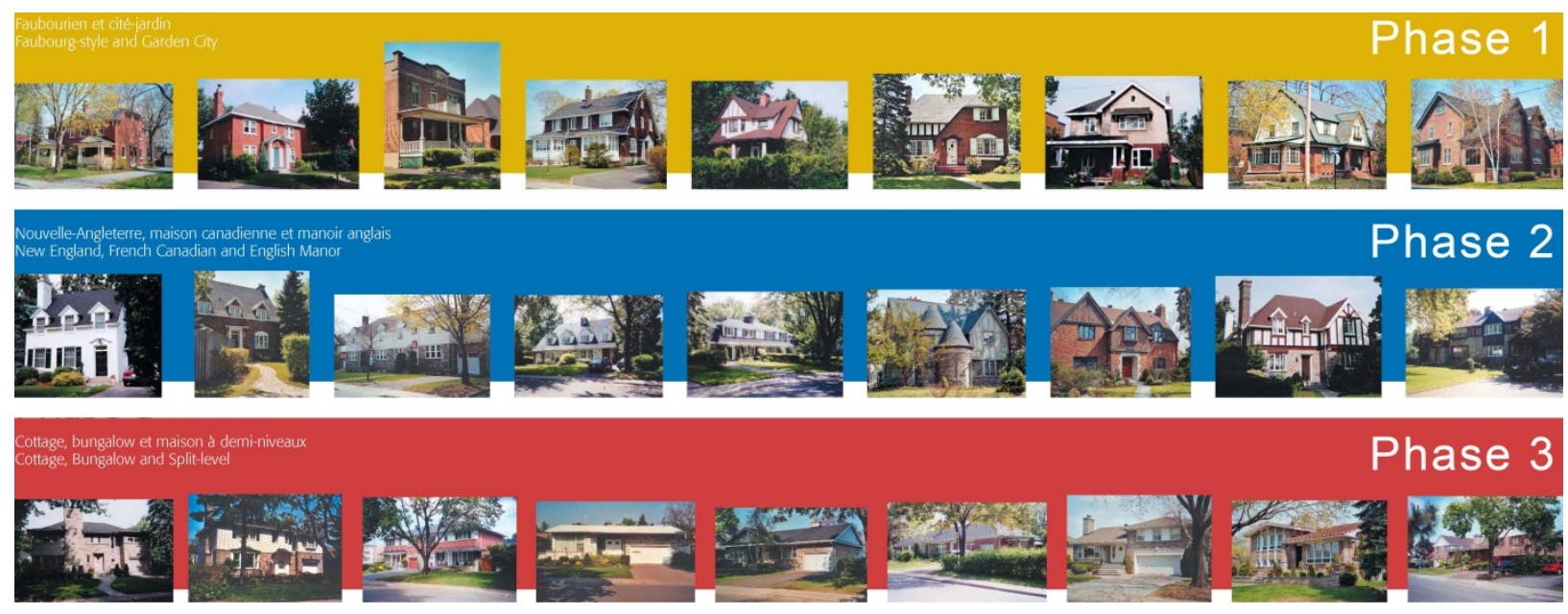

Figure 3-15: Diversity of housing types in Town of Mount Royal Source: The Site Planning and Architectural Integration (PIIA), 2007

In the year 2002, a 2106 square feet apartment was constructed at the heart of the Town at the corner of Rue Merit Crescent and Graham Boulevard very close to the central station and all the 
other services that the Town offers. This building houses 72 families providing them the opportunity to access the major transit station within 3 minutes (Figure 3-16). As shown in this figure, the condominiums, apartments and townhouses are mostly located at the center of the Town along two diagonal roads, and along the railway line.
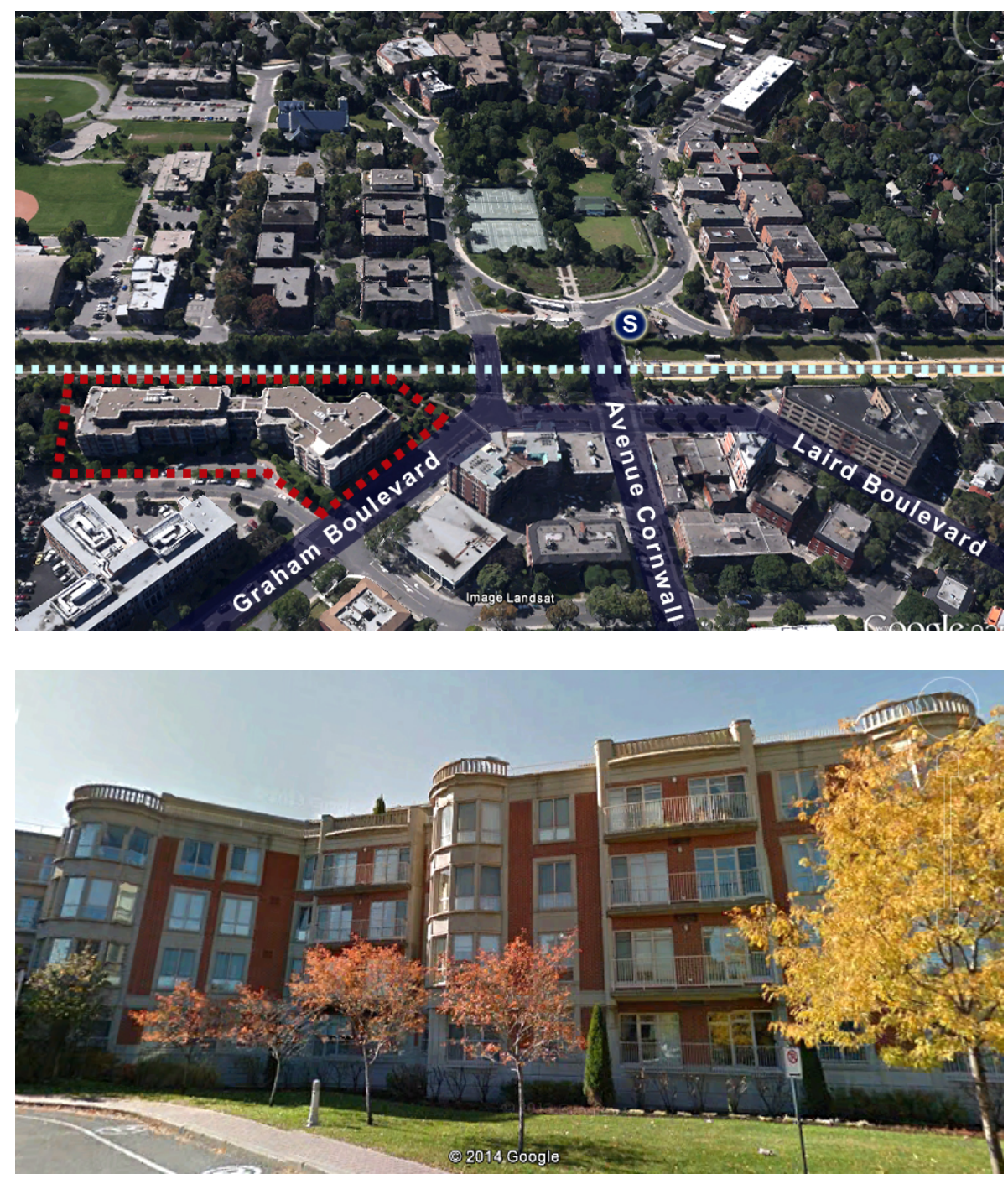

Figure 3-16: New higher density residential development close o central station Source: Google Earth, 2014

The following illustration compares Calthorpe's transit-oriented development with TMR's Town Center (Figure 3-17): 

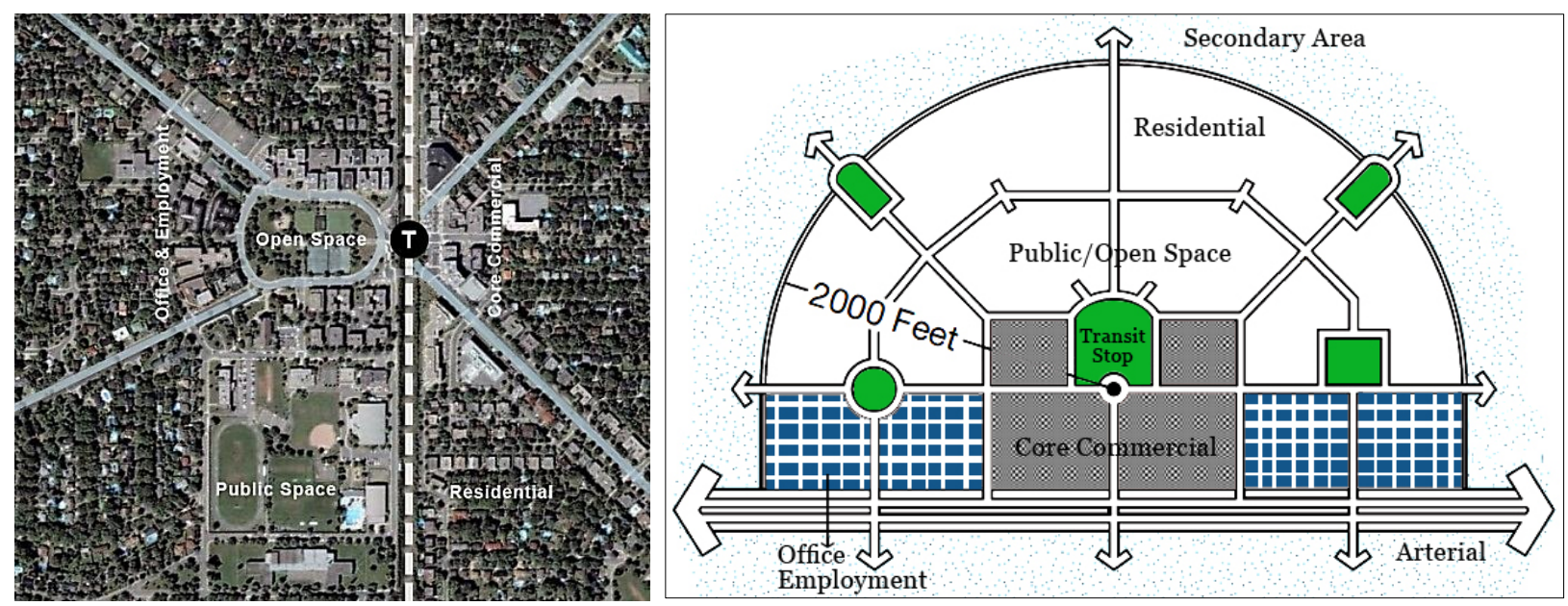

Figure 3-17: Comparing TOD defined by Calthorpe with Town of Mount Royal Source: Stern, Fishman \& Tilove, 2013

Studying the history of TMR and analyzing the design genesis and stages of the Town, the following key design principles can be noticed (Stern, Fishman \& Tilove, 2013):

- The design gridiron plan (standard North American practice)

- The system of diagonal boulevards superimposed on standard plans (City Beautiful)

- The curvilinear street pattern (Riverside by Olmsted)

The following are more highlighted:

- The proximity of the buildings with greatest density to the train station. Accessible public transit station both at the center of the Town and the edges (transit-oriented development)

- A combination of housing types and residential densities, with apartments along major thoroughfares to support ridership on the commuter train

- Grid oriented differently than that in Montreal which provides greater sun exposure

- Network of parks and public open/recreational spaces

- Commerce and retail within walking distance of residences 
- Providing ample side-walks, bicycle paths, on-site commercial services and off-site parking to encourage pedestrians not to use their automobiles.

- Creating high-quality pedestrian environment and access including setbacks and buffered sidewalks separated from automobiles by greening.

The following diagram analyzes the design and density of the Town (Figure 3-18). Comparing to what was proposed a century ago, the Town's plan including the lots' size, location of parks and streets' orientation is almost unchanged. The map indicates that the curvilinear street, defined later as the green necklace of parks in the preliminary plan by Todd, is mostly within the $800 \mathrm{~m}$ walking distance of the central transit station. The rest of the Town is served by metro and rapid bus lines $(165,435,119,16)$. Higher residential densities are mostly located around the train station and along one of the main thoroughfares.

In sum, Town of Mount Royal is a unique real estate development. Its marvelous tunnel and transit system were the main cause that enhanced the value of the adjacent land and the development of the Town of Mount Royal was a way to capture some of that value. However, the Town was not just an intense, profitable transit-adjacent development that makes a weak relationship between transit and development. The next chapter, compares the new TODs with Town of Mount Royal and shows how modern projects are similar to such old communities. 


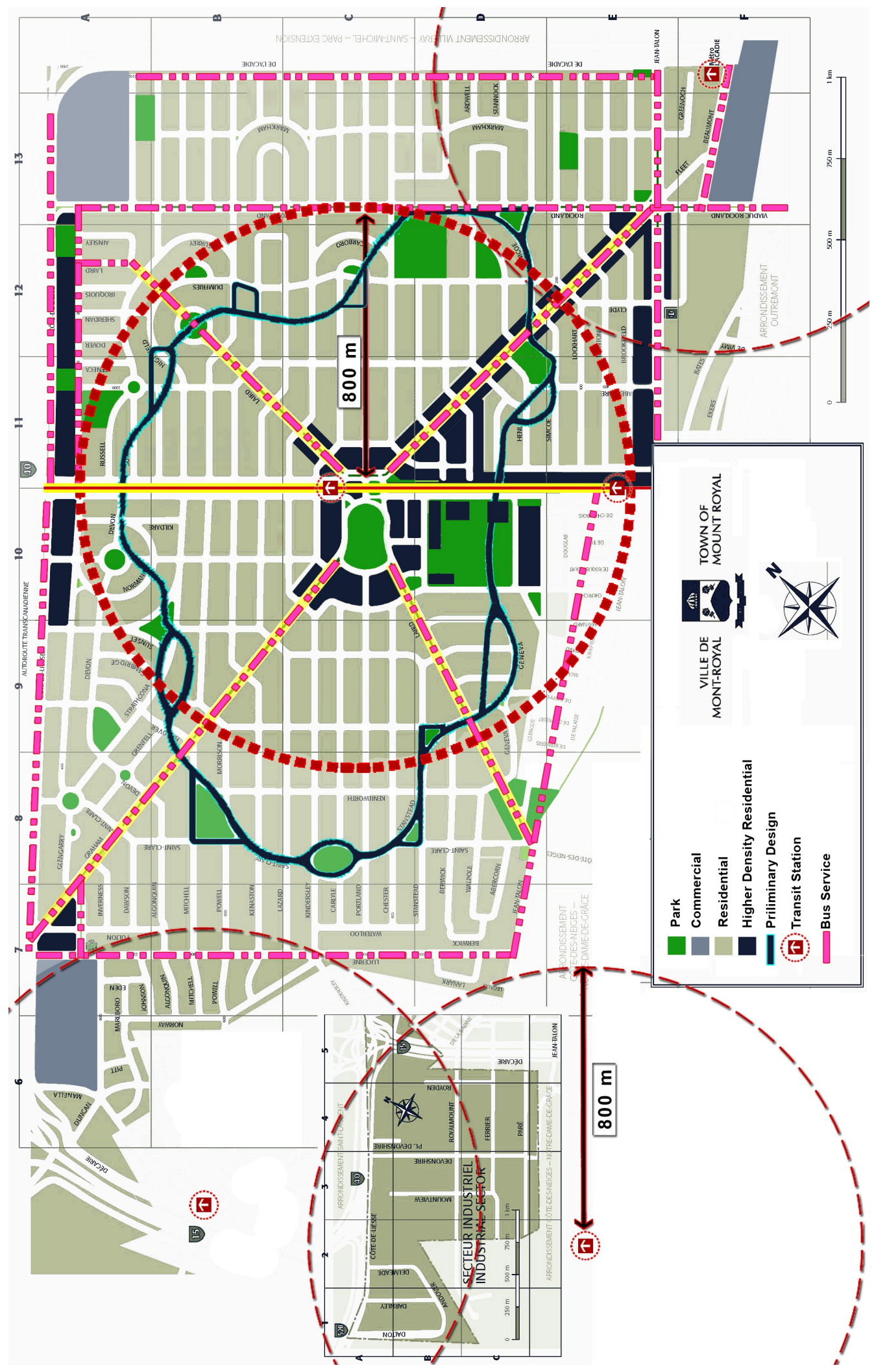

Figure 3-18: Town of Mount Royal, today: analyzing design and density Source: Ville de Mont-Royal, 2014, edited and analyzed by author 


\subsubsection{Transportation Facilities and Accessibility}

Transportation immediately outside the subject area has been adequate since its initial development. The area is approximately in the middle of the Island of Montreal and therefore lends itself to construction of distribution centers (Figure 3-15).

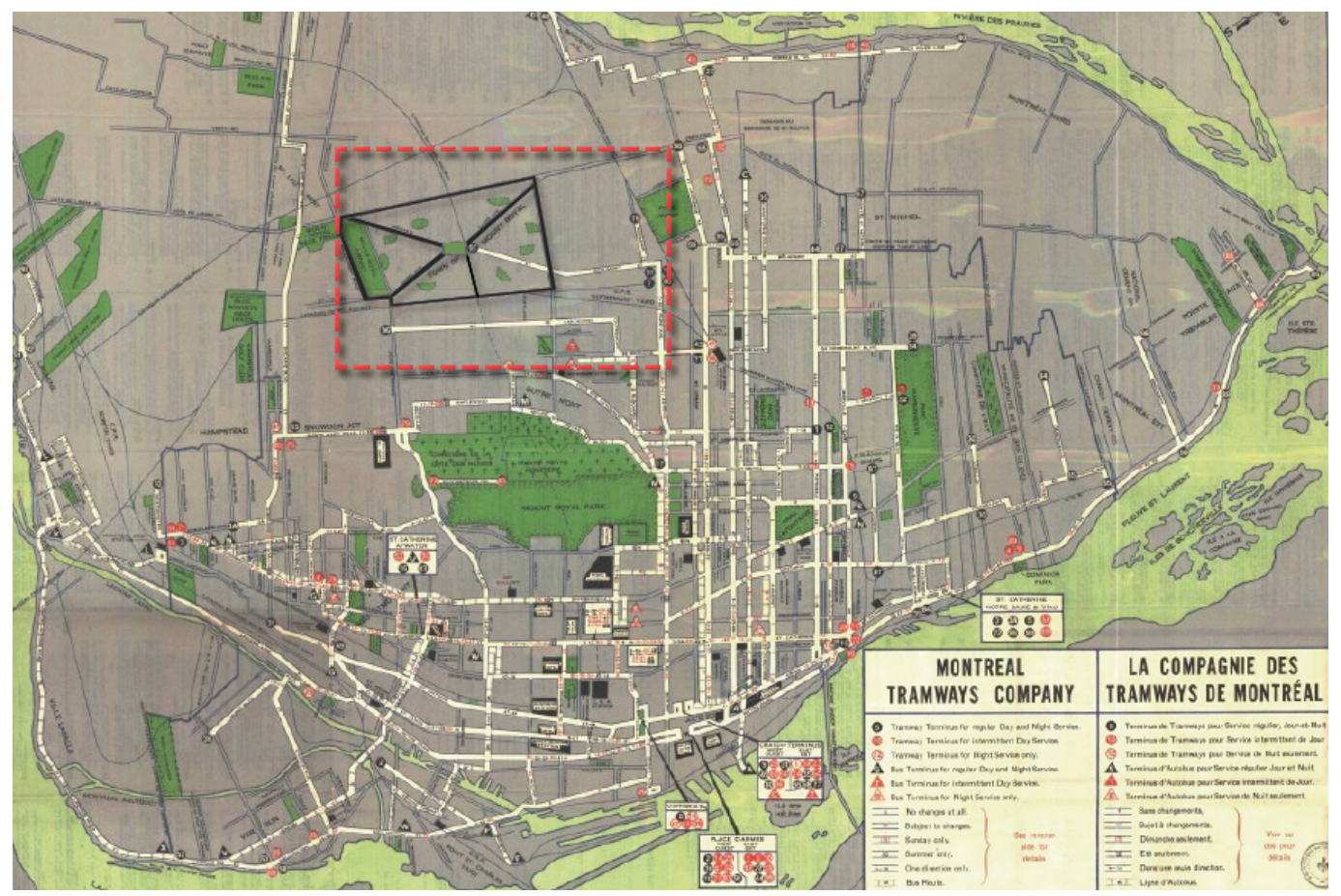

Figure 3-19: Montreal Tramway Line, 1941

Source: Laurendeau, 2012

TMR is adjacent to a main east-west road which links highways connecting major Ontario points to the west with major Quebec points to the east (at the nexus of the main east-west (Autoroutes 20 and 40) and north-south (Autoroutes 15 and 13)) (Figure 3-16). Moreover, the Trans-Canada Highway on the north side makes better connections to points in eastern Canada and the northeastern United States. The Town's central location also puts it a short 15-minute drive from the Montréal-Trudeau International Airport. 

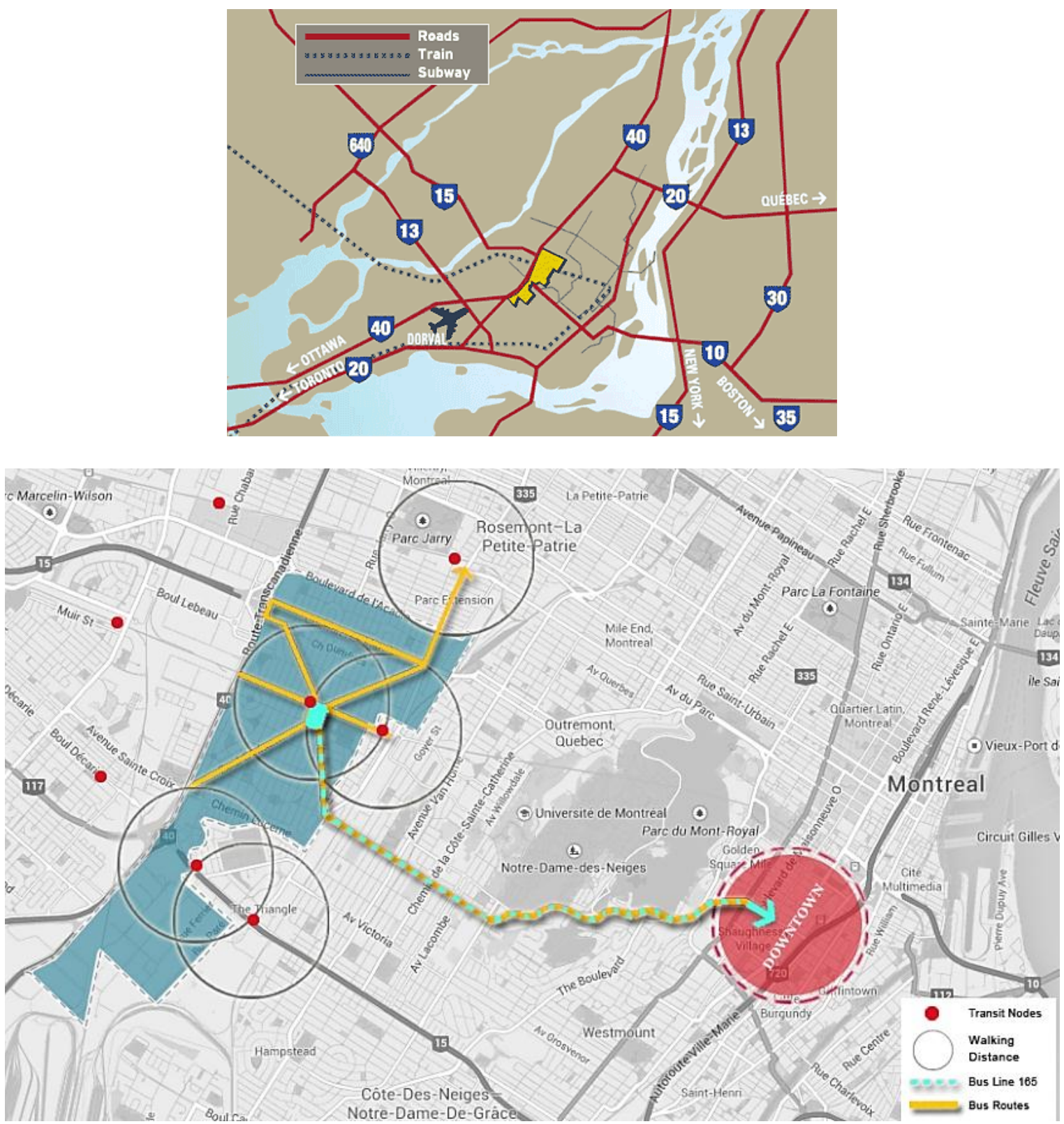

Figure 3-20: How to reach Town of Mount Royal Source: Ville de Mont-Royal, 2014

The area is well served by rail. Canadian Pacific Railway serves the southern part of the site and the CNoR the northern section. However the entire area is within interswitching limits of Parsley Interchange, located one mile to the west. Therefore, all plants and warehouses have access to both railways through interswitching. And the area is well-adapted to rail-oriented industry. 
Besides relying on your car, you can travel to the Town by taking Société de Transport de Montréal (STM) buses 16, 119, 165 and 435 or riding the metro to L'Acadie or Namur stations, both of which are located just outside the town limits. Alternatively, the Agence Métropolitaine de Transport (AMT) has two stops on its Deux-Montagnes suburban train line (Mont-Royal and Canora stations) that take you between town center and downtown Montreal.

Some studies reveal that wile rail and road facilities were unusually good outside the subject area, the internal road conditions were not so favorable (Ville de Mont-Royal, 2014). Reference to observation of traffic conditions showed that the roads were too narrow. The advent of the tractor-trailer truck for intercity transport and local delivery had created serious traffic problems. Moreover, the Town building regulations did not demand sufficient off-street parking. The result was a line of parked cars on each side of the street with traffic endeavoring to move through a "one way" channel in the mid-road.

\subsubsection{Growth, Change and Citizen Involvement}

The viable community of Mount Royal, however, cannot continue living based on the initial plan proposed by Todd before the First World War. As highlighted by Peter Jacobs (2012), a careful review of successive plans of the Town of Mount Royal reveals changes to the pattern of residential lots to accommodate civic and educational needs to the south of the Town Center, changes to the disposition of residential lots along the necklace of parks that Todd proposed as a counterpoint, to the community grid, the provision of a large golf course to the east, and latter two shopping centers at the north-west and south-east of the initial plan.

What is now admiring about Todd's plan is the adaptability it has that can meet the changing needs of the community over time without losing any of its initial integrity(Jacobs, 2012). In fact 
the plan was, and continues to be, embraced by an active citizenry committed to building informal social networks through recreation and social clubs, as well as to the beautification of their living environment. The gardening tradition was established by the first residents of the Town, is among the most notable tradition of citizen involvement. In fact, this activity complemented the 'official' plan for wide boulevards and parks and is still very much active to this day.

Having all these perspectives in mind, it is worth mentioning what Professor Peter Jacobs claimed about the design genesis and growth of the Town in its centennial in 2012:

"I suggested earlier that the genesis of the plan for the "Model City" was not truly derived from the Garden City movement or form the City Beautiful movement based on the Beaux Art tradition. Over time, however, the provision of professional, commercial, and industrial opportunities in the Town and the visual, social and environmental impact of private and public concern for the civic landscape have shaped a mature and viable community. There is a certain irony in the fact that these changes to the Town may well have given birth to another kind of Garden City and City Beautiful, albeit not necessarily that first envisaged by Ebenzer Howard - A beautiful city of gardens rather than a Garden or City beautiful."

In his Preliminary report to the Ottawa Improvement Commission, Frederick Gage Todd noted that "You may ask, is it reasonable to look so far ahead as one hundred years or more, and to make plans for the generations in the distant future". We are now in a position to respond (Jacobs, 2012). 


\section{Chapter 4 CANADIAN TODS AND TMR; A COMPARATIVE STUDY}

This chapter presents an overview of transit-oriented development in Canada. The study introduces a cross Canada survey done by Canada Mortgage and Housing Corporation (CMHC) and discusses its methodology and comparative outputs. The aim is to explore how a transitoriented suburban community like Town of Mount Royal stacks up with TOD strategies and design features integrated into the CMHC projects. Accordingly, the study investigates the success factors and challenges of these projects to find out whether today's transit-oriented development norms grew out of such early suburban communities.

\subsection{Recent Canadian Efforts in Transit-Oriented Development}

Over the last decade, smart growth has emerged as a substantial movement and attracted diverse interest across Canada and the United States (CUTA, 2004). Many provincial and local governments are working hard to understand exactly what smart growth looks like, and how they can make it happen. The challenge of maintaining livability and sustainability in the face of increasing urban population growth across Canada is driving the emergence of compact, mixedused developments centered on transit nodes (CMHC, 2009). One of the most important aspects of maintaining livability in urban development is the link between land use and transportation. Land-use mix and density affect the viability of transit and other transportation systems. On the other hand, the availability of transit, affects land use and density patterns to leverage the infrastructure use towards development.

Despite the purported benefits and the clear momentum behind the TOD concept, few examples of true TOD have been built in Canada and, more broadly, in North America. Many cases claiming to be TOD have been criticized as actually representing TAD or "transit adjacent 
development", implying that the level of integration with the transit station is weak and the project lacks the required density and mixed uses to support the necessary level of activity (Transportation Cooperative Research Program, 2002). Many other TOD cases are in the midst of planning processes that illustrate the time and energy it can take to make TOD a reality. Infill projects, which typically require care to satisfy zoning requirements and meet the concerns of sensitive neighbors, can be made even more complex by some TOD characteristics like higher densities and mixed uses (CUTA, 2004).

Moreover, there has been a significant amount of attention to the TOD concept in policy documents related to the planning development of the largest Canadian municipalities, including Montreal, Ottawa, Calgary, Edmonton and Vancouver (Feldman, Lewis \& Schiff, 2012). This documentation, however, is focused on providing policy direction, design guidelines and descriptive case studies and does not provide any critical or scholarly analysis of TOD concept.

Many older, more established neighborhoods and urban centers developed before the Second World War demonstrate successful integration of transportation infrastructure and services into community design (CMHC, 2009). During the mid-1990s, TOD became a hot topic in the smart growth debate; however, it has been around much longer than that in cities like Toront (CUTA, 2004). In 1950s and 60s, many compact development nodes grew around stations on the Yonge subway line. Reaching back even further to the 1800 s, the corridors that evolved around streetcar lines in major cities exemplified TOD — dense, diverse, pedestrian-friendly, and actively supportive of transit. These places, characterized by pedestrian-oriented routes, a range of land uses and parcel sizes, a mix of residential densities and, well-established transit nodes, support a range of efficient and reliable transportation options (CMHC, 2009). 
To shine a light on the challenges and success factors of TODs and their impact on residents, CMHC commissioned a series of case studies. They selected 10 developments across Canada. By interviewing key players including transit authorities, developers and municipal planners and surveying occupants, the study examines the factors contributing to successful projects and the challenges faced by both private developers and public agencies in carrying them out (NHRC, 2009).

\subsubsection{A Brief Description of Some Case Studies}

CMHC released a report on November 2009. By examining examples of TODs in cities across Canada, CMHC tries to provide lessons for future TODs. The research team conducted a literature review, selected potential projects, conducted interviews, assembled graphics and wrote the case studies. The team selected 10, among 25 developments, based on the following criteria: within a ten-minute walk of a transit station or major stop, mixed-use, pedestrianoriented and have transit-supportive densities (CMHC, 2009). The selected developments required to cover a range of transit types and locations, from both urban and suburban sites and from across Canada. They also covered a range of building heights and densities depending on the urban context.

The research team surveyed the occupants of the case studies to shed light on their motivations for choosing to live there, level of satisfaction, travel patterns and demographic information. The transit authorities were interviewed for the views on regional growth and transit development as well as the relationship between land use and transit planning. The developers also determined their motivation for pursuing the project, as well as profitability, success factors, challenges and how they were overcome. The City's planning objectives for the node, municipal involvement in 
providing walk-cycle connections, zoning and other regulatory issues, financial issues and neighborhood inputs were also determined through interviewing the municipal planners.

The selected case studies are from Torornto, Ottawa, Vancouver, Calgary, Mississauga, MontSaint-Hilaire and Sainte-Therese (Quebec), and Halifax (CMHC, 2014). All of these studies highlight compact mixed-use residential developments which are built within a 5 minute walk $(800 \mathrm{~m})$ of a transit node with the aim of intensification of neighborhoods and supporting public transit ridership.

- Collingwood Village, Vancouver, British Columbia

This project is a high-density mixed-use urban village centered around a Sky Train Station in Vancouver (CMHC, 2009). Collingwood Village is the largest master-planned community in British Colombia (2700 units, 11.3 hectares) which contains a number of neighborhood amenities including a community center, daycare and community police station that have made this a truly complete urban village (Figure 4-3).
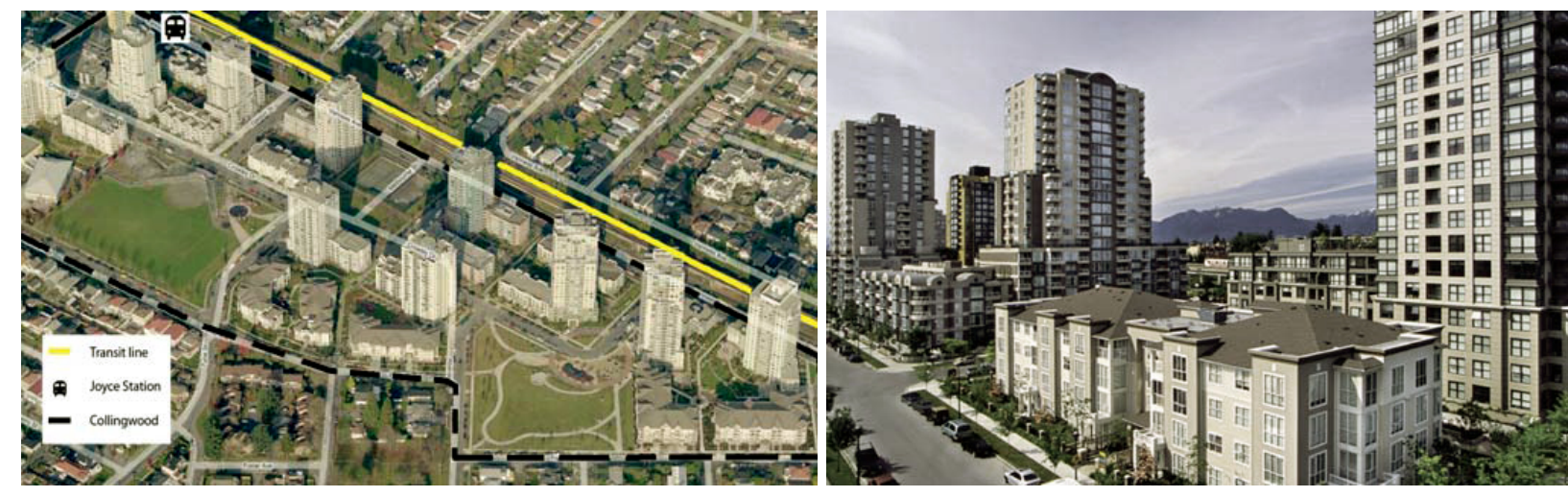

Figure 4-1: Collingwood Village adjacent to Joyce-Collingwood Sky Train Station Source: CMHC, 2009

This project is considered as a highly successful transit-oriented development that combines transit supportive densities with good connections to the transit station and a mixed-use urban 
village. According to a survey of residents, 56 percent use transit as their main means of travel to work.

- Equinox, Toronto, Ontario

The Equinox project located at Scarborough, a suburban area of the City of Toronto, contains 689 units in two, 37-story, high-rise towers with retail uses at-grade in one building (CMHC, 2009). The buildings are located immediately adjacent to a rapid transit (light rail) station and were directly connected to the station by a pedestrian bridge in 2007. Both transit users and residents benefit from a pedestrian network and road system throughout the site (Figure 4-1). Although, this project has a relatively high density but, it cannot be considered as a community.

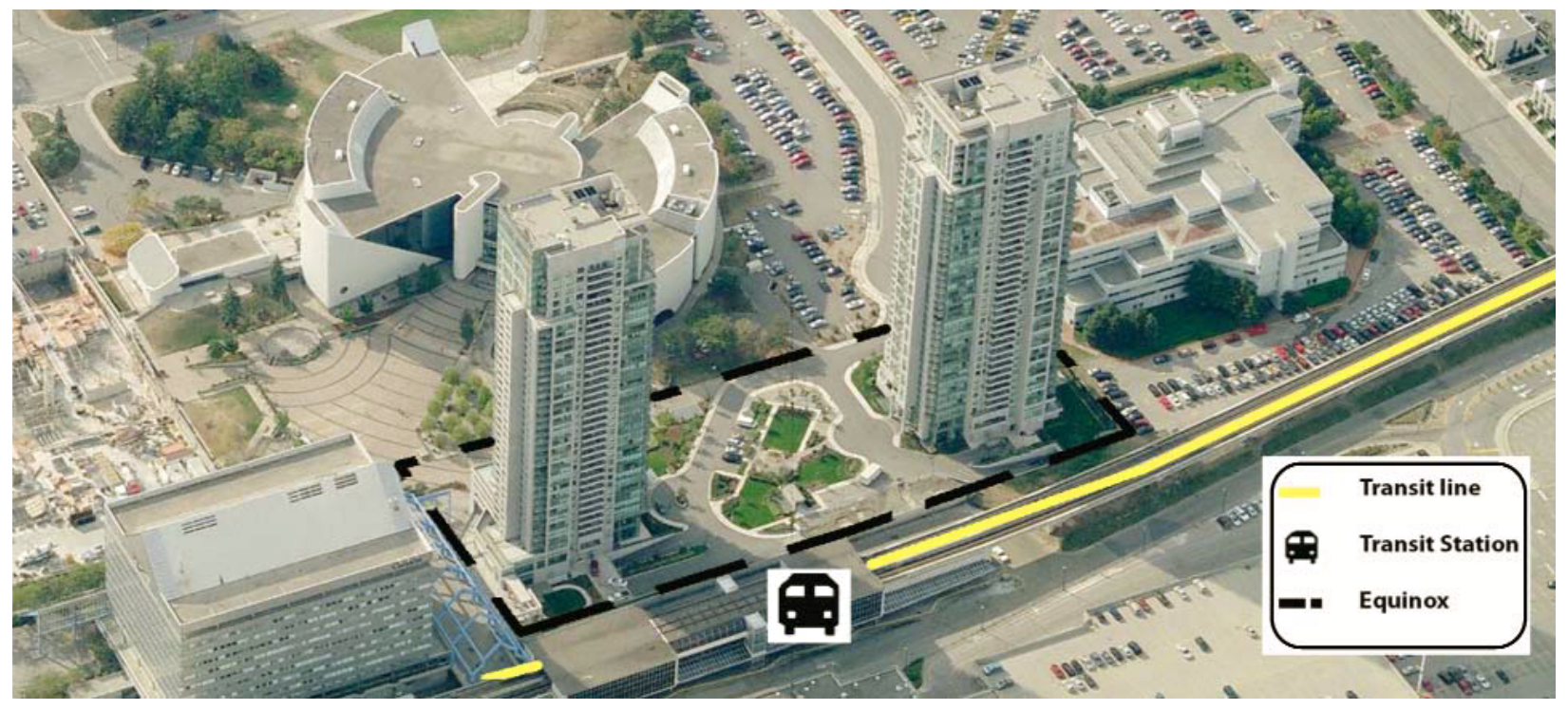

Figure 4-2: Location and boundaries of the Equinox development Source: CMHC, 2009

- The Bridges, Calgary, Alberta

The Bridges is a master-planned urban village, located in one of Calgary's old neighborhoods (CMHC, 2009). Completed in 2011, 1575 multi-family units were built to accommodate up to 
2500 residents. The project also included significant commercial and retail uses. A light rail transit station is located just south of The Bridges. This project was planned as a compact urban village that respects, enhances and takes cues from the surrounding neighborhoods, while creating a distinct environment on its own. Land use and design criteria of height, massing, and scale of this project relate well with surrounding lower density environment. The CMHC study focuses on the Acqua and Vento buildings, a sample project which includes 44 townhouses located in two buildings above street oriented retail (Figure 4-2).
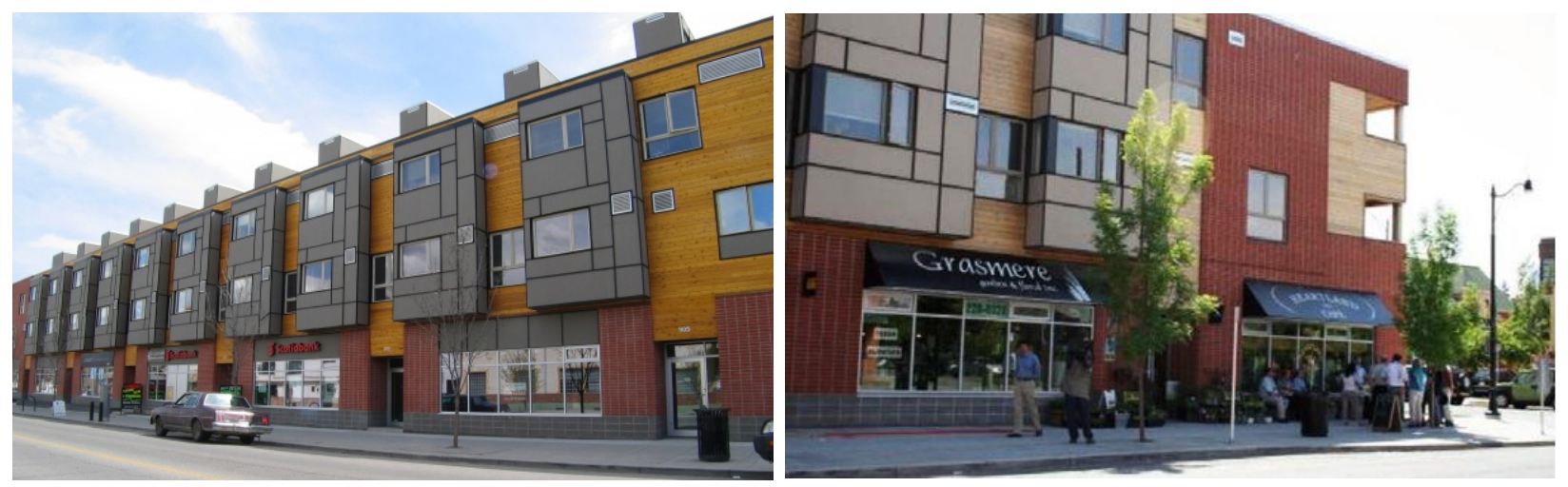

Figure 4-3: Acqua (left) and Vento (right), residential units above street-oriented retail Source: CMHC, 2009

\subsubsection{Transit-Oriented Development in Montreal}

As mentioned so far, TOD is an urban planning concept often proposed as a solution to suburban sprawl. The majority of research on TOD is descriptive, though some research has examined the impact of TOD on travel behavior. A recent theory of TOD production proposes that the rarity of completed TOD projects in North America is due to either a weak consumer demand, or a variety of supply barriers (Feldman, Lewis \& Schiff, 2012). 
The Montreal metropolitan region has an extensive transit network and variety of innovative development projects have come up in recent years. A recent study has examined the perspective of land developers regarding supply barriers to TOD in the Montreal metropolitan region and found structural barriers as principle obstacle to the supply of TOD. A lack of suitable land, an insufficient supply of suburban transit service, and a lack of common definition of TOD are mentioned as the major obstacles to TOD production in this context.

In 2005, the Communauté Métropolitaine de Montréal (CMM) adopted a framework which revealed the growing interest in multifamily housing and a new tendency of residential growth being constricted toward the center of the region. CMM concluded that these tendencies highlight the need to rethink urban planning in terms of certain new planning theories, such as Smart Growth, New Urbanism and TOD (CMM, 2005). Seven years later, a new plan was adopted by CMM which aimed at "orientation of 40 percent of household growth around access points to the structuring metropolitan network of public transportation". The three criteria supporting this objective describe the appropriate location, density targets and planning for TOD (CMM, 2012, p.10). In this regard TOD concept has gained much attention and support through policy statements at the regional level.

In recent years, the City of Montreal's highest order urban planning document, Plan d'urbanisme, has embraced the concept of TOD. A major orientation of this plan is to create "structuring transportation networks that are efficient and well integrated into the urban fabric" and the objective is thus to "consolidate and add value to land in relationship to existing and projected transportation networks and subsequently to support urbanization that favors use of public transport" (Ville de Montréal, 2005, p.33 \&43). In order to meet these objectives, the City proposes to favor mixed-use development within 500 meters of certain transit stations, metro 
stations and transit corridors. Figure 4-4 indicates two TOD projects that have been developed along the suburban radial train network in the past decade.

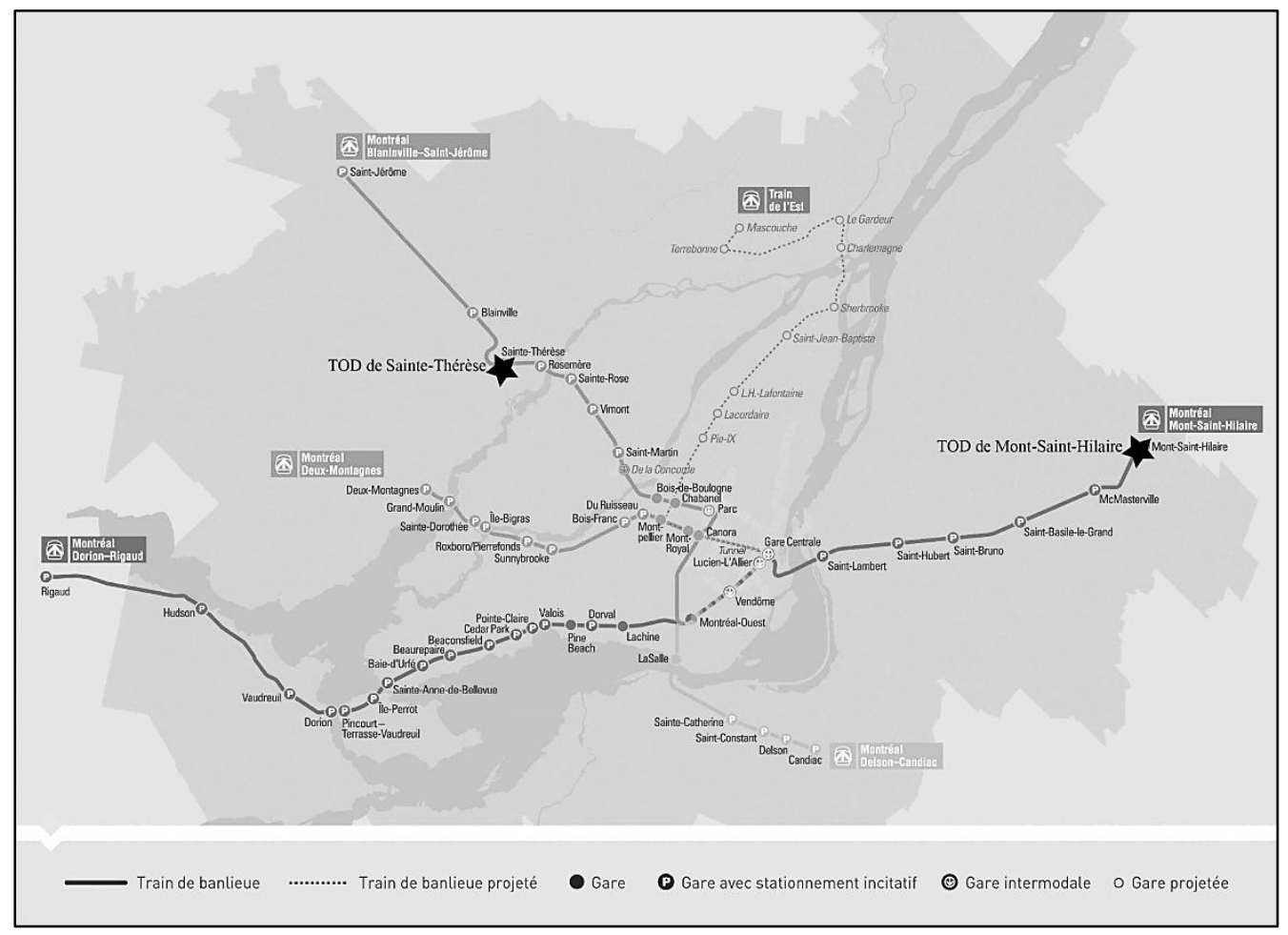

Figure 4-4: Montreal Radial Suburban Train Network including the TOD projects in Sainte-Thérese and Mont-Saint-Hilaire Source: Agenec métropolitaine de transport, 2006

Given this context, development of new TOD in Montreal can benefit from the supportive policies of CMM, the City of Montreal's Plan d'urbanisme and the lessons learned in the examples of the two mentioned suburban TODs (Feldman, Lewis \& Schiff, 2012).

In response to car-dependent suburban development off the Island of Montreal which undermined the transit use and increased traffic congestion in the metropolitan region, the Metropolitan Transportation Agency (AMT-Agence Metropolitaine de Transport) was established in 1995 (CMHC, 2007). The aim was to promote public transit use, improve existing 
services and plan for new facilities. AMT established a commuter line servicing the South Shore near the St. Lawrence River and extended the service to Mont-Saint-Hilaire.

- Village de la Gare, Mont-Saint-Hilaire, Québec

The Village de la Gare in the Town of Mont-Saint-Hilaire (located about $40 \mathrm{~km}$ from downtown Montreal) is considered to be first, master-planned, transit-oriented development project in Quebec (CMHC, 2007). The project was started in 2002 after commuter train service was introduced linking Mont-Saint-Hilaire to Montreal. The key players collaborating in this development were the municipality, the metropolitan transit authority and a private developer. Being completed in 2012, this project includes 1000 residential units (single-detached, duplex, townhouse), approximately $2300 \mathrm{~m}^{2}$ of commercial space, a primary school, public open space and landscaping, bicycle routes and pedestrian pathways, all within 200-750 meters of commuter rail station (Figure 4-5). As shown in the picture, for train users and commercial center patrons there are plenty of parking spaces (1000 in total) next to the station.
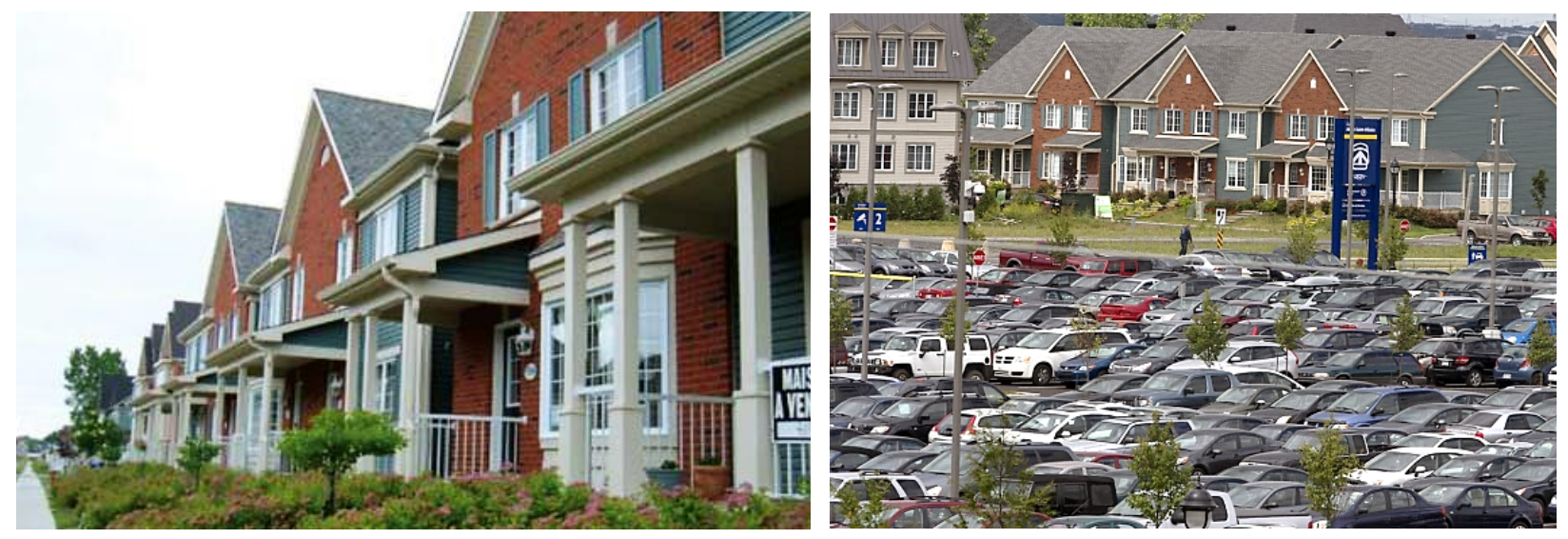

Figure 4-5: Pedestrian-oriented streetscape free of garages and driveways and the train station surrounded by parking in Village de la Gare, Mont-Saint-Hilaire, Quebec Source: CMHC, 2009 (left) - Le Devoire, 2014 (right) 


\subsection{Comparing Town of Mount Royal with CMHC Research Highlights}

In this part, the TOD strategies and design features which were integrated into the CMHC case studies as well as the success factors and challenges of these projects are discussed to explore how a transit-oriented suburban community like Town of Mount Royal stacks up with them. Accordingly, the study investigates the strength and weaknesses in the design and development of TMR. In other words, the attempt is to find out whether today's transit-oriented development norms grew out of such communities.

\subsubsection{What TOD Features Are Integrated into the Projects?}

The literature review indicated that TODs should include the following features:

- Convenient and pleasant pathways for pedestrian circulation

- High-quality public spaces

- Transit-supportive densities with the densest forms near the transit station

- Diversity of housing types and mix of land-uses

- Proper parking specifications

The residential development around transit nodes can be served by a number of transit types, including: rapid-express bus, light rail transit, grade-separated rail, underground (subway, metro) and elevated (sky train), commuter rail and commuter ferry (CMHC, 2009).

The Town of Mount Royal as explained in the third chapter is served by two main train stations (Gare Mont-Royal and Gare Canora) right in the middle of the town as well as the most rapid and efficient STM bus in Montreal (line 165) which goes directly to downtown through Cotedes-Neiges Street (Figure 4-7). 
The west part of the TMR (west side of Autoroute decarie) is the industrial zone and therefore, transportation facilities are more required for the east part which is the residential zone. This image indicates the zones which are served by train and metro services. The blue areas situated outside the large circles can take the bus (16-119-165-435) to reach the nearest metro or train station in less than 5 minutes.

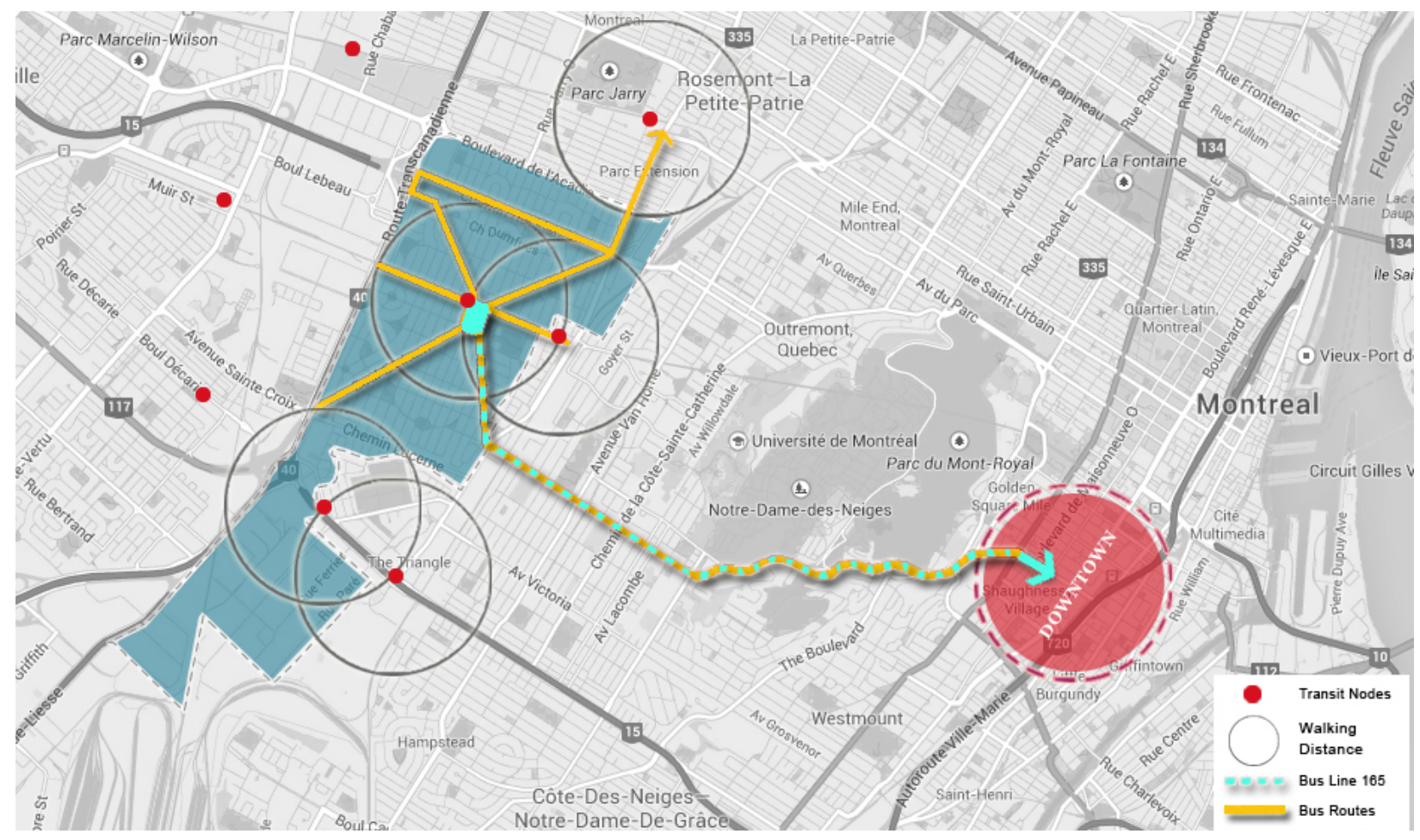

Figure 4-6: Town of Mount Royal, walking distance to the transit services Source: Google Map, 2014, Diagram by Author

The Mont-Royal station with a large central park next to it has created a pleasant and inviting environment for pedestrians to come and use the public transit facility. There are two other transit stations which interface with the rest of the neighborhood encouraging the residents to use active transportation rather than their own cars (Figure 4-8). 

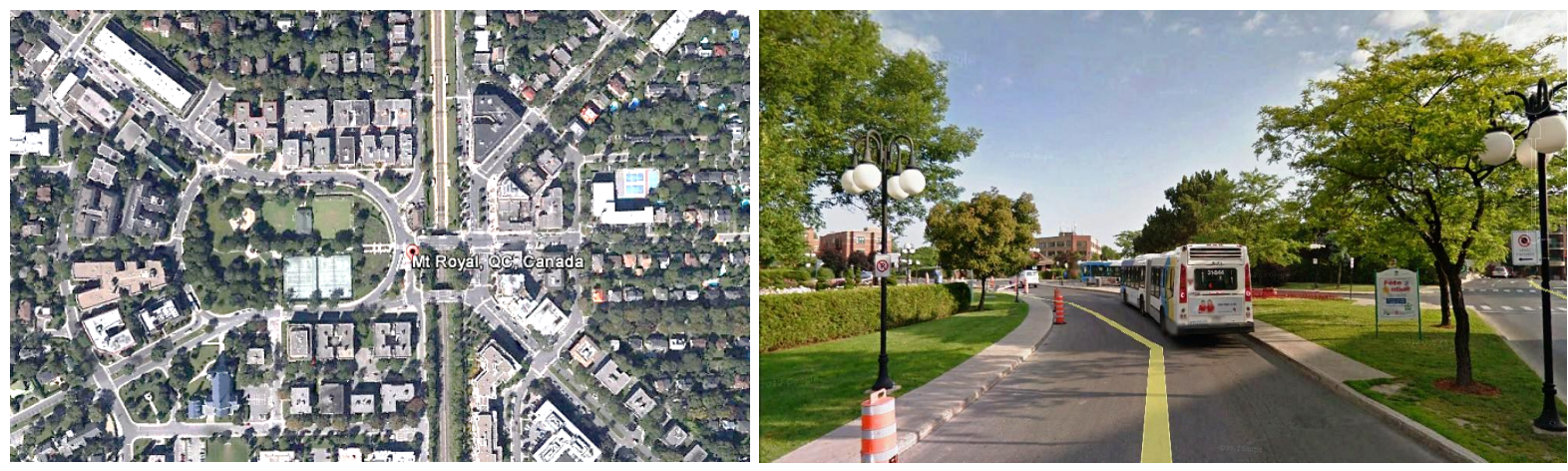

Figure 4-7: Pleasant and inviting routes leading to the central train station Source: Google Earth, 2014

The CMHC projects are well within $800 \mathrm{~m}$ (at their furthest point) of the transit station, which puts them within the 10-minute people are generally willing to walk. In these developments the routes are generally on paths separated from roads or on pedestrian-oriented streets, except in two developments where the pedestrian environment is pleasant within the project site but not on busy roads between it and the transit station. In spite of this, many of the transit stations are uninviting, utilitarian design.

In Town of Mount Royal the residential density decreases as we go further form the center of the town but it never becomes less than the average 15 units per net acre $(\mathrm{du} / \mathrm{ac})$ that is considered necessary to support viable light rail (Calthorpe, 1993). This density is met with a mix of housing types, including small lots, single family, townhouses, condominiums, and apartments. Unlike typical suburban land use patterns, TMR provides a higher concentration of households in close proximity to transit services and core commercial areas.

Except for one, all CMHC projects exceed the minimum residential density of $15 \mathrm{du} / \mathrm{ac}$. Also, all but two of the projects are mixed-use; however, those two developments are located within mixed-use areas. the following table compares TOD features in TMR with CHMC projects. 
Table 1: comparing TOD basic principles in Town of Mont Royal with CMHC projects

\begin{tabular}{|c|c|c|c|c|c|}
\hline Project & \multirow{2}{*}{$\begin{array}{c}\text { Pedestrian } \\
\text { connection } \\
\text { to station (distance, } \\
\text { form and quality) }\end{array}$} & \multirow{2}{*}{$\begin{array}{l}\text { Housing } \\
\quad \text { mix }\end{array}$} & \multirow{2}{*}{ Other land uses } & \multirow{2}{*}{$\begin{array}{l}\text { Gross res. } \\
\text { density } \\
\text { (uph) }\end{array}$} & \multirow{2}{*}{ Parking } \\
\hline Size & & & & & \\
\hline $\begin{array}{l}\text { Town of } \\
\text { Mount Royal, } \\
\text { Montreal }\end{array}$ & \multirow{2}{*}{$\begin{array}{l}50-800 \mathrm{~m} \text { within the } \\
\text { green necklace of } \\
\text { parks. Outside this } \\
\text { area the } \\
\text { neighborhood is } \\
\text { served by frequent } \\
\text { bus lines }\end{array}$} & \multirow[t]{2}{*}{$\begin{array}{l}\text { - detached } \\
\text { homes, } \\
\text { duplexes, } \\
\text { townhouses, } \\
\text { low-rise } \\
\text { apartments }\end{array}$} & \multirow[t]{2}{*}{$\begin{array}{l}\text { - commercial } \\
\text { uses, community } \\
\text { facility, school, } \\
\text { daycare, retail }\end{array}$} & \multirow{2}{*}{$\begin{array}{l}\text { - Minimum } \\
30 \text { and } \\
\text { maximum } \\
100 \text { close } \\
\text { to the } \\
\text { transit } \\
\text { station }\end{array}$} & \multirow[t]{2}{*}{$\begin{array}{l}\text { - } 1.5 \text { spaces per res. } \\
\text { unit }\end{array}$} \\
\hline 743 hectares & & & & & \\
\hline $\begin{array}{l}\text { Collingwood } \\
\text { Village, } \\
\text { Vancouver }\end{array}$ & \multirow{2}{*}{$\begin{array}{l}\text { - } 25-700 \mathrm{~m} \\
\text { - pedestrian-oriented } \\
\text { streets (trees, } \\
\text { traffic calming, small } \\
\text { blocks with } \\
\text { mid-block } \\
\text { connectors) and paths } \\
\text { through well- } \\
\text { designed open spaces } \\
\text { - station uninviting }\end{array}$} & \multirow{2}{*}{$\begin{array}{l}\text { - 4-storey } \\
\text { townhouses/ } \\
\text { garden apts. } \\
\text { and 6- to } \\
26 \text {-storey } \\
\text { condo and } \\
\text { rental } \\
\text { apartments }\end{array}$} & \multirow{2}{*}{$\begin{array}{l}\text { - grocery store, drug } \\
\text { store, } \\
\text { school, community } \\
\text { center, daycare, } \\
\text { other } \\
\text { retail, neighborhood } \\
\text { policing center } \\
\text { - m2 are } 6 \% \text { of the } \\
\text { total } \\
\text { site area }\end{array}$} & \multirow[t]{2}{*}{239} & \multirow[t]{2}{*}{$\begin{array}{l}\text { - } 1.35 \text { spaces per res. } \\
\text { unit in } \\
\text { phase } 1 \text { and } 1.04 \text { in } \\
\text { phase } 2 \\
\text { - all underground }\end{array}$} \\
\hline 11.3 hectares & & & & & \\
\hline $\begin{array}{l}\text { The Bridges } \\
\text { (Acqua and } \\
\text { Vento), } \\
\text { Calgary }\end{array}$ & \multirow[t]{2}{*}{$\begin{array}{l}\text { - The Bridges: } 100 \text { to } \\
600 \mathrm{~m} \\
\text { - Acqua and Vento: } \\
\text { up to } 575 \mathrm{~m} \\
\text { - excellent } \\
\text { - paths through parks } \\
\text { and } \\
\text { pedestrianoriented } \\
\text { streets with } \\
\text { amenities, } \\
\text { traffic calming } \\
\text { - pedestrian bridge } \\
\text { over arterial road }\end{array}$} & \multirow[t]{2}{*}{$\begin{array}{l}\text { - The } \\
\text { Bridges: mix } \\
\text { of } \\
\text { multi-family } \\
\text { units } \\
\text { (3-12 } \\
\text { storeys), } \\
\text { townhouses } \\
\text { and } \\
\text { live/work } \\
\text { units } \\
\text { - Acqua and } \\
\text { Vento: } \\
\text { townhouses }\end{array}$} & \multirow[t]{2}{*}{$\begin{array}{l}\text { - The Bridges will } \\
\text { be } 10 \% \\
\text { street level } \\
\text { commercial/ } \\
\text { retail and } 32 \% \text { open } \\
\text { space } \\
\text { - make the station a } \\
\text { retail node } \\
\text { - Acqua and Vento } \\
\text { commercial m } 2 \text { are } \\
65 \% \\
\text { of the total site area }\end{array}$} & \multirow[t]{2}{*}{$\begin{array}{l}\text {-avg. } 320 \\
\text { close to } \\
\text { station, } \\
\text { avg. } \\
210 \text { close } \\
\text { to existing } \\
\text { neighborho } \\
\text { od }\end{array}$} & \multirow{2}{*}{$\begin{array}{l}\text { - } 1.25 \text { spaces per res. } \\
\text { unit, } \\
\text { underground } \\
\text { - } 1 \text { space } / 7 \mathrm{~m} 2 \text { net } \\
\text { floor area } \\
\text { for food services } \\
\text { - on-street parking } \\
\text { was } \\
\text { accepted for ground- } \\
\text { floor } \\
\text { non-res., which } \\
\text { reduced } \\
\text { parking need by } \\
25 \% \\
\text { - Acqua has } 19 \\
\text { commercial } \\
\text { spaces, Vento has } 9\end{array}$} \\
\hline 14.9 hectares & & & & & \\
\hline $\begin{array}{l}\text { Equinox, } \\
\text { Toronto }\end{array}$ & \multirow{2}{*}{$\begin{array}{l}\text { - } 25 \mathrm{~m} \\
\text { - excellent } \\
\text { - path and pedestrian } \\
\text { bridge }\end{array}$} & \multirow[t]{2}{*}{$\begin{array}{l}\text { - high-rise } \\
\text { condo }\end{array}$} & \multirow{2}{*}{$\begin{array}{l}\text { - retail } \\
-\mathrm{m} 2 \text { are } 6 \% \text { of the } \\
\text { total } \\
\text { site area }\end{array}$} & \multirow[t]{2}{*}{543} & \multirow[t]{2}{*}{$\begin{array}{l}\text { - } 1.1 \text { spaces per unit, } \\
\text { all underground, } \\
\text { except } 6 \text { surface }\end{array}$} \\
\hline 1.27 hectares & & & & & \\
\hline $\begin{array}{l}\text { Village de la } \\
\text { Gare, Mont- } \\
\text { Saint-Hilaire }\end{array}$ & \multirow[t]{2}{*}{$\begin{array}{l}\text { - 200-750 m } \\
\text { - good } \\
\text { - paths and pedestrian- } \\
\text { friendly streets } \\
\text { with sidewalks }\end{array}$} & \multirow[t]{2}{*}{$\begin{array}{l}\text { - detached } \\
\text { homes, } \\
\text { duplexes, } \\
\text { townhouses, } \\
\text { low-rise } \\
\text { apartments }\end{array}$} & \multirow[t]{2}{*}{$\begin{array}{l}\text { - will include } \\
\text { commercial } \\
\text { uses, community } \\
\text { facility } \\
\text { and a school }\end{array}$} & \multirow[t]{2}{*}{$\begin{array}{l}30 \text { uph } \\
\text { multi-family } \\
\text { and } 20 \text { uph } \\
\text { single- } \\
\text { family }\end{array}$} & \multirow[t]{2}{*}{$\begin{array}{l}\text { - } 1.5 \text { spaces per res. } \\
\text { unit, surface } \\
\text { - } 444 \text { surface at Park \& } \\
\text { Ride }\end{array}$} \\
\hline 73 hectares & & & & & \\
\hline
\end{tabular}




\subsubsection{Transit: A Motivational Factor for Developers and Occupants}

In essence, Mount Royal was conceived as a real estate venture that would give the railway essential access to downtown Montreal (McCann, 2010). In other words, the train service, and so the transportation facility, were the key to the Town's founding and development. Therefore, as reported in the $75^{\text {th }}$ Anniversary Souvenir Booklet, the municipality mainly concerned whether the service will get modernized and spur a return to the trains in the years to come, or will it be abandoned and become a memory like the Mount Royal Golf Course.

Before the existence of the tunnel, it took forty minutes to reach the Town taking the way round the Mount Royal Mountain (Jacobs, 2012). Obviously, if there was no rapid transit facility that could ease the accessibility to downtown by making the trip as short as seven minutes, a community wouldn't start to live quickly grow there. Therefore, the transit proximity was the number one motivating factor for both the builders and residents to live there.

Similarly, all developers in CMHC projects felt that transit proximity helped market the project to occupants or was a motivation in choosing to build in that location. Two projects in Vancouver and the Equinox in Toronto said that it was a major motivation and resulted in a price premium (CMHC, 2009). Half of the surveyed occupants mentioned proximity to transit as the number one motivating factor. In all projects, the surveyors took transit significantly more than CMA average. The ridership was double and even triple the average in half of the developments. Almost all respondents who took transit to work walked to the station in six developments. Roughly, one-third of the respondents mentioned the access to transit as the reason for accepting a higher housing price. In one of the developments with older and wealthier respondents than average, where there were fewer people and more cars per household, the ridership was half the 
average. In this specific project, most respondents cited other motivating factors for choosing that location, including: shopping, parks, trails and proximity to other amenities.

Although transit to work rates were significantly higher than average, most respondents may have chosen that location to make their existing travel patterns more convenient.

\subsubsection{Financial Success and the Role of Municipalities}

As explained in chapter 3, key administrative positions were held by active or one-time officials of Land Company (McCann, 2010). The most important of these people was Darling who was the first mayor of the Town for 21 years. Darling was a shareholder of the Land Company and a director of several other companies linked financially to Mount Royal's land base. Through much of his 21 year region, he held the role of Town Manager, guiding the day-to-day growth of the Town. In fact, not only Darling, but all the promoters, architects, engineers, town officials and others who were involved in conceiving, designing, building and managing Mount Royal before and after the First World War, developed and planned TMR as an alternative version of the suburban ideal, initially, in conjunction with the Land Company's profit-driven search for a way to market, and later, with the Town Council's on-going commitment to implement the Land Company's plan for building a 'Model City'.

Having all these information, we conclude that municipality, the transit authority and the developer were partners in the development of the transit station and Mount Royal neighborhood.

In CMHC projects, all but one developer claimed that the project met their profit expectations and for two of them the profit expectations were even exceeded (CMHC, 2009). The projects met the municipality's goal for compact, mixed-use, pedestrian-oriented development around 
transit nodes. In four cases, the municipality initiated the projects, assembling and/or rezoning public land parcels they targeted for TOD near transit stations and selling those properties to develop with specific design criteria. In the case of Village de la Gare, somehow similar to the Town of Mount Royal, transit authority and municipality were partners in the development of the transit station and neighborhood. Other projects were driven by private developers, but supportive of overall municipal goals for TOD near existing transit station, which facilitated approvals and cooperation between partners. In the case of Portland Hill in Halifax, the transit station was added after the residential development had already begun.

All the CMHC projects involved the municipality and the developer working co-operatively (CMHC, 2009). The developers felt that municipal support was a key success factor. The municipality provided flexibility on parking and zoning in some cases and in some others provided marketing of the area and cost sharing on infrastructure and amenities. In return, they required the developers to provide certain amenities, such as pedestrian links to the train station.

\subsubsection{Land Economics and Selling prices}

Undoubtedly, the axiom of land economics reflects that accessibility dictates the land value (McCann, 2010). In Town of Mount Royal, the properties located closest to existing tram line, as well as nearest the northern section of Montreal that was curling west around the Mountain, commanded amongst the highest price. Accordingly, the purchased land formed a U-shape, matching the rectangular boundaries of the long lots that distinguished this historic landscape. Taking into account the following parameters, this land form varied later: the placement of other railroads such as a CPR branch line to the northeast; intensive farm settlement along several 
major roads (St Laurent and Cote de Liesse); village, collage, church, and seminary location; competing speculative land ventures.

In CMHC projects, comparing with the cost of a dwelling was local average selling prices or rents for the same type of unit for new construction in the same year, the cost of a dwelling was the same as the local average for four and lower in two of the CMHC projects (CMHC, 2009).

\subsubsection{Local Amenities and the Occupants' Satisfaction}

Town of Mount Royal had a significant landscape not only for its unity in residential land use, but also for its diversity of housing forms and architectural styles. Close to the town's central square, various public buildings, business blocks, and recreational facilities share space with walk up apartments. Most of the local amenities in TMR have been built after the Second World War including shops, garages and clubs $\left(75^{\text {th }}\right.$ Anniversary Souvenir Booklet). The proximity to these amenities also was an important factor in raising the residents' satisfaction. TMR has 5 well-defined commercial sectors. They are located right on the four corners and in the middle of the Town's residential half, east of highway 15 . Besides, the town is served by two mixed-use centers which provide recreational purposes as well (Figure 4-9).

The CMHC projects generally had excellent access to urban or natural amenities or both (e.g. vibrant, mixed-use neighborhoods, waterfronts, trails) (CMHC, 2009). This was the prime motivator for one third of the surveyors and a major motivation for most of the developers in their investment decisions.

In all CMHC developments, satisfaction rates were high (CMHC, 2009). Design, appearance, and size of the homes, neighborhood amenities and appearance were the most attractive features among others. The path to transit station was very convenient and pleasant for all respondents. 
They gave the highest satisfaction rate to safe sidewalks along the street, trees and other landscaping along the walking paths that are separate from the street.

Most respondents said their previous dwelling was of a lower density than their current one. Most also said they paid more for this dwelling than for their previous one. They accepted this higher price mostly for access to neighborhood amenities and architectural design features of the units.

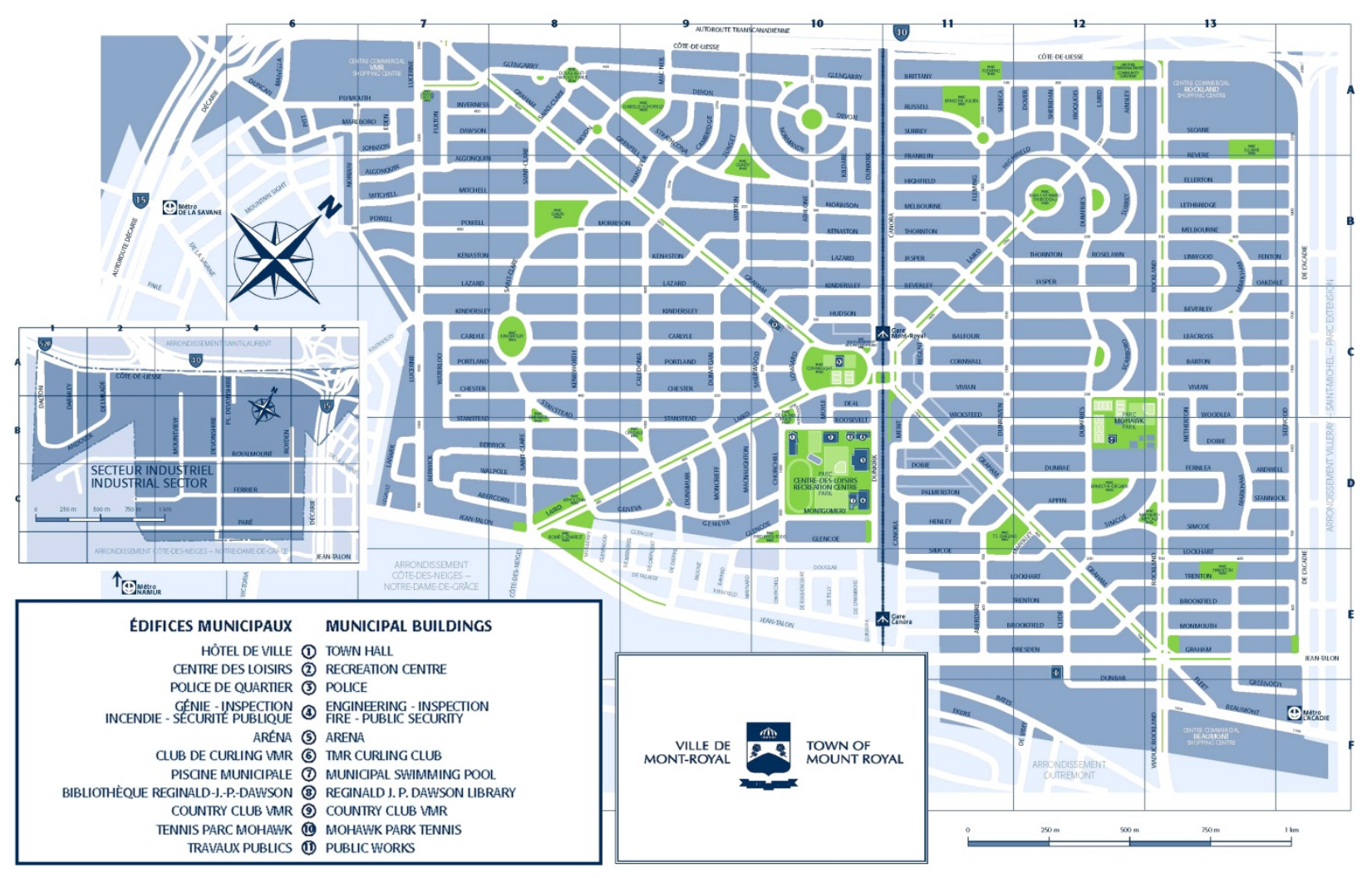

Figure 4-8: Town of Mount Royal, Parks and Local Amenities Source: Ville de Mont-Royal, 2014 


\section{Chapter 5 CONCLUSIONS AND RECOMMENDATIONS}

This chapter concludes the thesis by providing a summary of achievements and offers recommendations for further research.

\subsection{Transit-Oriented Development, So Far}

In this report, the concept of transit-oriented development was introduced as a crucial means of coordinating relatively intensive land uses and multiple transportation modes. The research supplemented prior literature on TOD and also focused on Town of Mount Royal, an early suburban community and an outstanding satellite development with certain planning principles that now form part of standard planning procedures in Canada.

The TOD principles which were summarized in the literature review are not new; they are simply a return to the timeless goals of urbanism, in its best sense (Calthorpe, 1993). They are principles which over time have created our most treasured man-made environments and remained true to the human dimension and our deepest social aspiration; however, their evolution with culture and technology is considerable. Introducing some early examples of TOD in Canada and U.S., the literature review built up the argument for chapter three and four.

In the third chapter Town of Mount Royal was introduced as a transit-oriented development. It was a large-scale real estate development on a property owned by a transit agency. The actual aim of developing that community was to generate revenue for the transit agency and the municipality. This project was predicted on a purely financial rational rather than a broad vision of how transit could work in tandem with the surrounding neighborhood. However, the "highest and best use" in financial terms is not always the best for either transit users or the neighborhood. 
In chapter 4, several modern transit-oriented developments across Canada were introduced and an overview of the survey's comparatives outputs was presented. These cases were evidences that indicate TOD can provide many other benefits besides capturing increases in land value.

Comparing the strategies and design features which they have adopted to those of the Town of Mount Royal, the study concludes that the modern TOD concept shares much in common with the idea of the Garden City, from the dawn of the twentieth century, in which more or less selfsufficient suburbs were centered on commuter train stations (Jacobson \& Forsyth, 2008). The similarity between the contemporary idea of TOD and more traditional urban forms is strong, and in many ways, TOD is actually a repackaging of what was for many years the typical form of center city and suburban development in cities across North America.

However, from the CMHC study we understood that TOD is not a panacea to our post-war developments. Even with access to transit, it is often more convenient for residents of suburban neighborhoods to drive. Curvilinear streets, wide boulevards and large parking lots create an intimidating environment for pedestrians, in some developments, in a way that if they do take transit, they often arrive to the station by car. Therefore, as cities continue to grow, municipalities must create transit-supportive policies that encourage residents to take transit and start thinking about transportation in different ways. In one of the CMHC projects, the developer provided occupants with free bus passes for two years and a car shearing program (CMHC, 2009). TOD is therefore a shift away from the private automobile to more sustainable pedestrian/transit-oriented cities. However, in creating TODs, particularly those from scratch, planners must challenge many of the suburban-style development practices, and learn from communities like Town of Mount Royal, which are otherwise ignored. 
New TODs often have parking next to the station that encourages the use of car as a transition device. However, in case of TMR that is not the case, which is good. Further study of habitats of residents especially the use of cars could be useful in this regard.

This report provided insight into the early transit-based developments as well as current TOD practices in Canada. The study attempted to assess some of the best examples of TODs based on their formation process and post-development performance, and outline the lessons learned from these projects. However, this study is not without its limitations. All the information from the old TMR were not accessible including the level of satisfaction of the early occupants. The case studies selected varied significantly: some TODs were urban centers and contained several of elements necessary for successful TOD (high-density, mixed-use, etc.), while others where suburban areas transformed into TODs. The challenge of creating successful TOD is different for every municipality and policy makers must fully understand the context in which they are working.

\subsection{Future Transit-Oriented Development}

Whether it is called transit-oriented, transit-related, or transit-supportive, the integration of land use and transportation is a concept being adopted by municipal and regional governments throughout the world.

Transit-oriented development can realize its full potential only if it is seen as a new paradigm of development rather than as a series of marginal improvements (Dittmar \& Ohland, 2004). TOD should not be considered as a utopian strategy where the constraints of the market and realistic expectations of behavior and lifestyle patters are ignored. Conversely, the market and lifestyle patterns can and do change as a result of both various policy choices and sociocultural trends. 
The automobile was not always the dominant form of transportation, and suburban living was not always the desired lifestyle. Part of these changes in American life has been fostered by government policies such as the mortgage interest tax deduction and the subsidies for road infrastructure at the expense of alternative forms of transportation.

Transit ridership and interest in urban living are two parameters that never stop growing. However, they indicate that preferences may be changing. Accordingly, the government investment priorities have shifted away from the automobile toward other alternatives, such as transit, walking and biking (Dittmar \& Ohland, 2004). Transit-oriented development can respond to these changes by offering an alternative that yields social benefits and operates within the constraints of the market at the same time. To this end, a range of social and environmental problems can be solved in the twenty-first century.

As the environmental, social, commuting, and land use trends progress, the type of neighborhoods we envision will probably become more attractive. Defining a vision of transit and development that function complementarily is the first stem, though, it is not enough. The next step is to move that vision - in concept and reality - into the mainstream of real estate development. If TOD projects are to be successful and meet the goals of policy makers, transportation engineers, planners, and the general public, greater understanding of the general public, greater understanding of the successes and failures of TODs in terms of their urban design practices is needed (Jacobson \& Forsyth, 2008). 


\section{Bibliography}

100 years of history. (2014) Retrieved from http://www.town.mountroyal.qc.ca/index.php?id $=712$

Altoon, R., \& Alud, J. (2011). Urban transformations: transit-oriented development and the sustainable city. Australia: Images Publishing.

An overview of the history of the Town of Mount Royal is contained in Ville Mont-Royal/Town of Mount Royal, Livret souvenir 75e anniversaire/75th Anniversary Souvenir Booklet, Montreal: Ville Mont-Royal/Town of Mount Royal, 1987.

Badoe, D. A., \& Miller, E. J. (2000). Transportation Land-Use Interaction: Empirical Findings in North America, and their Implications for Modeling. Transportation Research Part D: Transport and Environment, 5(4), 235-263. http://dx.doi.org/10.1016/S1361-9209(99)00036-X

Belzer, D., \& Autler, G. (2002). Transit-Oriented Development: Moving from Rhetoric to Reality. Washington, DC: Brookings Institution Center on Urban and Metropolitan Policy.

Bernick, M., \& Cervero, R. (1997). Transit Villages in the 21st Century. New York, NY: McGraw-Hill.

Bertolini, L. (2000). Planning in the Borderless City: A Conceptualization and an Application to the Case of Station Area Redevelopment, Town Planning Review, 71(4), 455-475.

Bertolini, L., le Clercq, F., \& Kapoen, L. (2005). Sustainable accessibility: a conceptual framework to integrate transport and land use plan-making. Two test-applications in the Netherlands and a reflection on the way forward. Transport Policy, 12(3), 207-220.

http://dx.doi.org /10.1016/j.tranpol.2005.01.006

Boarnet, M. G., \& Crane, R. (2001). Travel by Design: The Influence of Urban Form on Travel. New York, NY: Oxford University Press.

California Department of Transportation. (2002). California Transit-Oriented Development Database, Retrieved from

http://transitorienteddevelopment.dot.ca.gov/miscellaneous/NewHome.jsp

Calthorpe, P. (1993), The Next American Metropolis: Ecology, Community, and the American Dream. New York: Princeton Architectural Press.

Canada Mortgage and Housing Corporation. (2009). Transit-Oriented Development Case Study: Collingwood Village, Vancouver, $B C$. 
Canada Mortgage and Housing Corporation. (2009). Transit-Oriented Development Case Study: Village de la Gare, Mont-Saint-Hilaire, QC.

Canadian Northern Montreal Land Company, Ltd., (1912). Mount Royal “The Model City”, Montreal, 10.

Canadian Northern Montreal Tunnel and Terminal Company, (1913). The Mount Royal Tunnel, Montreal . . being built for Mackenzie, Mann and Company, Ltd., Montreal.

Cervero, R. (1988). Land Use Mixing and Suburban Mobility. Transportation Quarterly, 42(3), 429-446.

Cervero, R. (2004). Transit-Oriented Development in America: Contemporary Practices, Impacts and Policy Directions. International Planning Symposium on Incentives, Regulations, and Plans - The Role of States and Nation-States in Smart Growth Planning.

Cervero, R., \& Duncan, M. (2002). Benefits of Proximity to Rail on Housing Markets. Journal of Public Transportation, 5(1), 1-18.

Cervero, R., \& Kockelman, K. (1997). Travel Demand and the 3 Ds: Density, Diversity and Design. Transportation Research Part D: Transport and Environment, 2(3), 199-219. http://dx.doi.org/10.1016/S1361-9209(97)00009-6

Cervero, R., Arrington, G.B., Smith-Heimer, J., Dunphy, R., Murphy, S., Ferrell, C., Goguts, N., Tsai, Y.-H., Boroski, J., Golem, R., Peninger, P., Nakajima, E., Chui, E., Meyers, M., McKay, S. and Witenstein, N. (2004), Transit Oriented Development in America: Experiences, Challenges, and Prospects, TCRPReport 102, National Academy Press, Washington, DC.

Cervero, R., Bernick, M., \& Gilbert, J. (1994). Market Opportunities and Barriers to TransitBased Development in California. Berkeley, CA: University of California Transportation Center.

Cervero, R., Ferrell, C., \& Murphy, S. (2002). Transit-Oriented Development and Joint Development in the United States: A Literature Review. Transportation Research Board of the National Academies.

Choko, M., \& Harris, R. (1989). L'e'volution du mode d'occupation des logements a' Montre'al et a'Toronto depuis le milieu du xixe sie' cle, Etudes et documents 61, Montréal: INRS Urbanisation, 21-8.

Dittmar, H., \& Ohland, G. (2004). The new transit town: best practices in transit-oriented development. Washington, DC: Island Press.

Ewing, R., \& Cervero, R. (2010). Travel and the Built Environment. Journal of the American Planning Association, 76(3), 265-294. http://dx.doi.org/10.1080/ 01944361003766766 
Fischler, R., Gordon, D., \& Newman, G. n.d., TMR Handout - Council for Canadian Urbanism.

Frank, L. D., \& Pivo, G. (1994). Impacts of Mixed-Use and Density on Utilization of Three Modes of Travel: Single-Occupant Vehicle, Transit, and Walking. Transportation Research Record (1466), 44-52.

Haider, M., \& Miller, E. J. (2000). Effects of Transportation Infrastructure and Location on Residential Real Estate Values: Application of Spatial Autoregressive Techniques.

Transportation Research Record (1772), 1-8.

Jacobs, P. (1983). Frederick G. Todd and the creation of Canada's urban landscape, in Landscape Preservation, special issue of The Bulletin of the Association for Preservation Technology, 27-37.

Jacobs, P. (2012). Mount Royal Model City: Suburb of the future in The Town of Mount Royal: A fabulous Story. Montreal: Ville Mont-Royal/Town of Mount Royal.

Jacobson, J., \& Forsyth, A. (2008). Seven American TODs: Good practices for urban design in Transit-Oriented Development projects. Journal of Transport and Land Use 1(2), 51-88.

Kalbfleisch, J. (2013). The royal gift: hundred years of Town history. Montreal, QC: Ville de Mont-Royal.

La Patrie (Montreal), 7 juillet 1911, 1.

Laurendeau, D. (2012). The Mount Royal Tunnel in The Town of Mount Royal: A fabulous Story. Montreal: Ville Mont-Royal/Town of Mount Royal, 1987.

Lund, H. M., Cervero, R., \& Wilson, R. W. (2004). Travel Characteristics of Transit-Oriented Development in California. California, CA: California State Polytechnic University Pomona.

McCann, L. (1996). Planning and building the corporate suburb of Mount Royal, 1910 - 1925 , Planning Perspectives, 11(3), 259-301. http://dx.doi.org/10.1080/026654396364871

Moudon, A. V., Hess, P. M., Snyder, M. C., \& Stanilov, K. (1997). Effects of Site Design on Pedestrian Travel in Mixed-Use, Medium-Density Environments. Transportation Research Record (1578), 48-55.

Nelson, D., Niles, J., \& Hibshoosh, A. (2001). A New Planning Template for Transit-Oriented Development. San José, CA: Mineta Transportation Institute College of Business, San José State University.

Parker, T., Mayer, D., Arrington, G. B., \& Smith-Heimer, J. (2002). Statewide Transit-Oriented Development Study Factors for Success in California: Final Report. 
Renne, J. L. (2005). Transit-Oriented Development: Measuring Benefits, Analyzing Trends, and Evaluating Policy. The State University of New Jersey, New Brunswick, NJ.

Renne, J. L., \& Wells, J. S. (2002). State of the Literature: Transit-Oriented Development, Assessing the Impacts of the New Jersey Transit Village Initiative. New Brunswick, NJ: Alan M Voorhees Transportation Centre, Edward J Bloustein School of Planning and Public Policy, Rutgers University.

Renne, J. L., \& Wells, J. S. (2004). Emerging European-Style Planning in the USA: TransitOriented Development. World Transport Policy \& Practice, 10(2), 12-24.

Renne, J. L., \& Wells, J. S. (2005). Transit-Oriented Development: Developing a Strategy to Measure Success. Washington, DC: Transportation Research Board.

Rohan, D. (1992). The Town of Mount Royal in Wolfe, J.M. \& Dufaux, F. (eds.) A Topographic Atlas of Montreal. Montreal, QC: McGill School of Urban and Regional Planning. 38-41.

The Canadian Nursery Company, (1919). Bowling Green [Prospectus], Montreal, 1912; and idem, Homes at Bowling Green [Prospectus], Montreal.

The Gazette (Montreal), 11 April 1912, 4.

Todd, F. G. (1907). "Premier Residential District of British Columbia," Point Grey Gazette.

Todd, F.G. (1901). Landscape architecture, The Canadian Architect and Builder, 77-8.

Todd, F.G. (1908). Point Grey, B.C.: a new departure in laying out a town-site, The Canadian Municipal Journal, 146-7.

Transit-Oriented Communities: A literature review on the relationship between the built environment and transit ridership (2010). A report by TransitLink, Metro Vancouver's transportation Network.

Tumlin, J., \& Millard-Ball, A. (2003). How to Make Transit-Oriented Development Work. Planning, 69. 14-19.

Vivian, H. (1910). Town planning and town housing, The Canadian Municipal Journal, 400-4. 